\title{
SURVIVAL ESTIMATES FOR THE PASSAGE OF SPRING-MIGRATING JUVENILE SALMONIDS THROUGH SNAKE AND COLUMBIA RIVER DAMS AND RESERVOIRS, 2003
}

\author{
Steven G. Smith, William D. Muir, Richard W. Zabel, Douglas M. Marsh, \\ Regan A. McNatt, John G. Williams \\ Fish Ecology Division \\ Northwest Fisheries Science Center \\ National Marine Fisheries Service \\ National Oceanic and Atmospheric Administration \\ 2725 Montlake Boulevard East \\ Seattle, Washington 98112-2097 \\ and \\ John R. Skalski \\ University of Washington \\ School of Aquatic \& Fisheries \\ 1325 Fourth Avenue, Suite 1820 \\ Seattle, Washington 98101-2509 \\ Report of research prepared for \\ U.S. Department of Energy \\ Bonneville Power Administration \\ Division of Fish and Wildlife \\ Contract DE-AI79-93BP10891 \\ Project 199302900
}

January 2004 


\section{EXECUTIVE SUMMARY}

In 2003, the National Marine Fisheries Service and the University of Washington completed the eleventh year of a study to estimate survival and travel time of juvenile salmonids (Oncorhynchus spp.) passing through dams and reservoirs on the Snake and Columbia Rivers. All estimates were derived from detections of fish tagged with passive integrated transponder tags (PIT tags). We PIT tagged and released a total of 19,840 hatchery steelhead at Lower Granite Dam. In addition, we utilized fish PIT tagged by other agencies at traps and hatcheries upstream from the hydropower system and sites within the hydropower system. PIT-tagged smolts were detected at interrogation facilities at Lower Granite, Little Goose, Lower Monumental, McNary, John Day, and Bonneville Dams and in the PIT-tag detector trawl operated in the Columbia River estuary. Survival estimates were calculated using a statistical model for tag-recapture data from a single release group (the "Single-Release Model").

Primary research objectives in 2003 were to 1) estimate reach survival and travel time in the Snake and Columbia Rivers throughout the migration period of yearling chinook salmon $O$. tshawytscha and steelhead $O$. mykiss; 2) evaluate relationships between survival estimates and migration conditions; and 3) evaluate the survival-estimation models under prevailing conditions.

This report provides reach survival and travel time estimates for 2003 for PIT-tagged yearling chinook salmon (hatchery and wild), hatchery sockeye salmon $O$. nerka, hatchery coho salmon $O$. kisutch, and steelhead (hatchery and wild) in the Snake and Columbia Rivers. Results are reported primarily in the form of tables and figures; details on methodology and statistical models used are provided in previous reports cited here. Results for summer-migrating fall chinook salmon will be reported separately.

Precise estimates of survival and detection probabilities were calculated for groups of yearling chinook salmon and steelhead during most of the 2003 migration season. Hatchery and wild fish were combined in some of the analyses. Among yearling chinook salmon tagged upstream of Lower Granite Dam and subsequently recombined into daily "release" groups at the dam, $73 \%$ were hatchery-reared and $27 \%$ were wild. For steelhead tagged upstream of the dam, the percentages were 55\% hatchery-reared and $45 \%$ wild. Among steelhead tagged at Lower Granite Dam, 39\% were hatchery-reared and $61 \%$ were wild. Among yearling chinook salmon tagged at the dam, less than $1 \%$ were hatchery-reared. Overall, the percentages for combined release groups used in survival analyses were $33 \%$ hatchery-reared yearling chinook salmon and $67 \%$ wild. For 
steelhead, the overall percentages were $41 \%$ hatchery-reared and $59 \%$ wild. The proportion of wild fish used for survival estimation in 2003 was higher than in past years.

Estimated survival from the tailrace of Lower Granite Dam to the tailrace of Little Goose Dam averaged 0.946 for yearling chinook salmon and 0.947 for steelhead. Respective average survival estimates for yearling chinook salmon and steelhead were 0.916 and 0.898 from Little Goose to Lower Monumental Dam tailrace; 0.904 and 0.708 from Lower Monumental to McNary Dam tailrace (including passage through Ice Harbor Dam); 0.893 and 0.879 from McNary to John Day Dam tailrace; and 0.818 and 0.630 from John Day to Bonneville Dam tailrace (including passage through The Dalles Dam).

Combining average estimates from the Snake River smolt trap to Lower Granite Dam, from Lower Granite to McNary Dam, and from McNary to Bonneville Dam, estimated annual average survival through the entire hydropower system from the head of Lower Granite reservoir to the tailrace of Bonneville Dam (eight projects) was 0.528 (s.e. 0.023 ) for Snake River yearling chinook salmon and 0.288 (s.e. 0.011 ) for Snake River steelhead.

For yearling spring chinook salmon released in the Upper Columbia River, estimated survival to McNary Dam tailrace was 0.637 (s.e. 0.003) for fish released from Leavenworth Hatchery, 0.655 (s.e. 0.010) for fish released from Entiat Hatchery, 0.553 (s.e. 0.014) for fish released from Winthrop Hatchery, and 0.508 (s.e. 0.014) for those from Methow Hatchery. Using pooled data, estimated survival for these groups was 0.928 (s.e. 0.009) from McNary Dam tailrace to John Day tailrace and 0.947 (s.e. 0.035) from John Day Dam tailrace to Bonneville Dam tailrace.

For 7 groups of steelhead released in the Upper Columbia River, estimated survival to McNary Dam tailrace ranged from 0.673 (s.e. 0.014) for fish released from Ringold Hatchery (97 km from McNary Dam) to 0.310 (s.e. 0.010) for fish released from Winthrop Hatchery (454 km from McNary Dam). Using pooled data, estimated survival for these groups was 1.004 (s.e. 0.016) from McNary to John Day Dam tailrace and 0.838 (s.e. 0.040) from John Day to Bonneville Dam tailrace.

Because of relatively cool spring temperatures, flow volumes during most of the 2003 yearling chinook salmon migration period were similar to flws during 2002, and only slightly higher than flows in 2001, which had the lowest recorded flows during the 11 years of this study. Late in the migration season, flows were much greater than during the previous 2 years, but by the time of this increase, most yearling chinook salmon had already migrated out of the Snake River. Because steelhead migrate later in the spring, a 
larger portion of them migrated during the higher flow period. Springtime spill levels were similar to 2002 and much higher than in 2001. Yearling chinook salmon survival in 2003 was similar to 2002 through most reaches, and much greater than in 2001. Steelhead survival in 2003 increased slightly through all reaches compared to 2002, and was much higher than in 2001, but remained depressed compared to other recent years for steelhead through some reaches and the entire hydropower system. PIT-tag detections on avian bird colonies in those reaches continued to account for much of the additional loss compared with recent years. 


\section{CONTENTS}

EXECUTIVE SUMMARY $\ldots \ldots \ldots \ldots \ldots \ldots \ldots \ldots \ldots \ldots \ldots \ldots$ iii

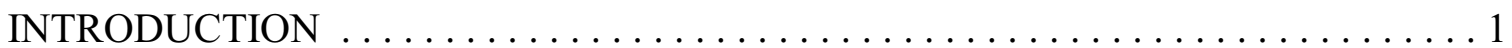

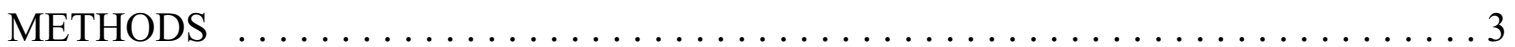

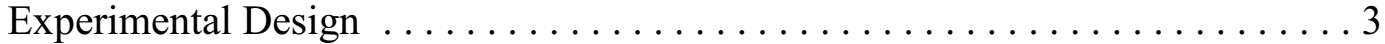

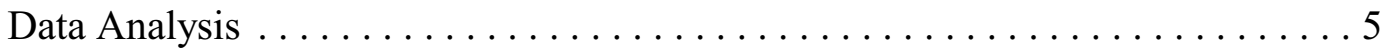

Comparison of Annual Survival Estimates $\ldots \ldots \ldots \ldots \ldots \ldots \ldots$

Flow and Spill In Relation to Juvenile Salmonid Survival and Travel Time . . . 8

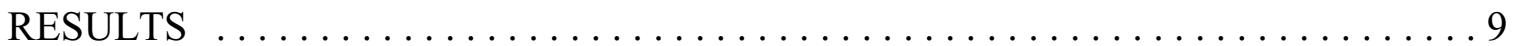

Lower Granite Dam Tagging and Release Information . . . . . . . . . . . . 9

Survival Estimation . . . . . . . . . . . . . . . . . . . . . . . . . . 9

Travel Time and Migration Rate . . . . . . . . . . . . . . . . . . 12

Tagging Details for Hatchery Steelhead PIT Tagged at Lower Granite Dam . . . 12

Comparison of Annual Survival Estimates . . . . . . . . . . . . 13

Flow and Spill In Relation to Juvenile Salmonid Survival and Travel Time . . 13

Survival Estimates from Point of Release to Bonneville Dam . . . . . . . . . . . 14

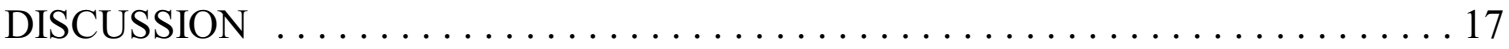

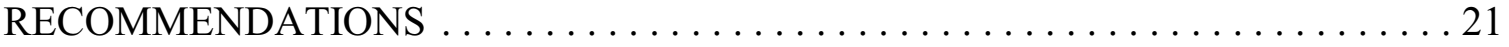

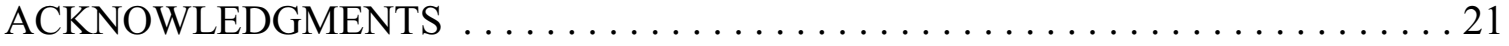

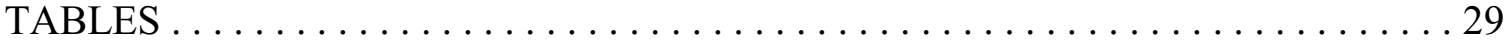

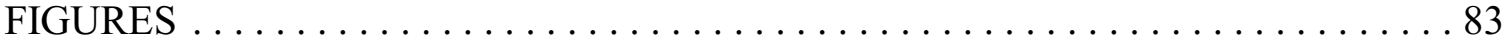

APPENDIX: Tests of Model Assumptions . . . . . . . . . . . . . . . . . . . 94 


\section{INTRODUCTION}

For juvenile chinook salmon Oncorhynchus tshawytscha, sockeye salmon $O$. nerka, and steelhead $O$. mykiss that migrate through reservoirs, hydroelectric projects, and free-flowing sections of the Snake and Columbia Rivers, survival estimates are essential to develop effective strategies for recovering depressed stocks. Many management strategies were based on estimates of system survival (Raymond 1979; Sims and Ossiander 1981) derived in a river system considerably different from today's (Williams and Matthews 1995; Williams et al. 2001). Knowledge of the magnitude, locations, and causes of smolt mortality under present passage conditions, and under conditions projected for the future, are necessary to develop strategies that will optimize smolt survival during migration.

From 1993 through 2002, the National Marine Fisheries Service (NMFS) and the University of Washington (UW) demonstrated the feasibility of using three statistical models to estimate survival of PIT-tagged (Prentice et al. 1990a) juvenile salmonids passing through Snake River dams and reservoirs (Iwamoto et al. 1994; Muir et al. 1995, 1996, 2001a, 2003; Smith et al. 1998, 2000a,b; Hockersmith et al. 1999; Zabel et al. 2001, 2002). Evaluation of assumptions for these models indicated that all were generally satisfied, and accurate and precise survival estimates were obtained.

In 2003, NMFS and UW completed the eleventh year of the study. Flow levels during the early portion of the 2003 spring migration were similar to 2002, and only slightly higher than in the drought conditions during 2001. However, flow levels were much greater during the later part of the migration in 2003. Spill levels were similar to 2002, much higher than in 2001. Research objectives were to:

1) estimate reach survival and travel time in the Snake and Columbia Rivers throughout the yearling chinook salmon and steelhead migrations;

2) evaluate relationships between survival estimates and migration conditions; and

3) evaluate the performance of the survival-estimation models under prevailing operational and environmental conditions. Additionally, as adult return information becomes available, as part of this study we will evaluate relationships between juvenile survival and subsequent adult returns for fish with different juvenile migration histories. 


\section{METHODS}

\section{Experimental Design}

The Single-Release (SR) Model was used to estimate survival for groups of PIT-tagged yearling chinook salmon, sockeye salmon, and steelhead released from Snake River Basin hatcheries and traps, Lower Granite Dam, and Upper Columbia River hatcheries and dams in 2003 (Cormack 1964; Jolly 1965; Seber 1965; Skalski 1998; Skalski et al. 1998; Muir et al. 2001a,b). Iwamoto et al. (1994) presented background information and underlying statistical theory.

During the 2003 migration season, automatic PIT-tag detectors (Prentice et al. 1990a,b,c) were operational in the juvenile bypass systems at Lower Granite (RKm 695), Little Goose (RKm 635), Lower Monumental (RKm 589), McNary (RKm 470), John Day (RKm 347), and Bonneville (RKm 234) Dams (Fig. 1). The most downstream site for PIT-tag detections was in the Columbia River estuary between RKm 65 and 84, where a pair trawl towed a PIT-tag detector (Ledgerwood et al. in press).

A large proportion of PIT-tagged yearling chinook salmon released above Lower Granite Dam were released for a multi-agency comparative survival study (CSS) in 2003. Of CSS fish detected at Lower Granite Dam in 2003, 66\% were collected and transported, and $56 \%$ of those detected at Little Goose Dam were transported. Similarly, both wild yearling chinook salmon and wild steelhead were PIT-tagged at Lower Granite Dam for transportation studies, and about $75 \%$ of those detected at Little Goose and $50 \%$ of those detected at Lower Monumental Dams were collected and transported. A large proportion of PIT-tagged fish in the Upper Columbia River were released for a study of transportation from McNary Dam; about $45 \%$ of those detected at McNary Dam were collected and transported. All other PIT-tagged fish detected at dams were diverted back to the river by slide gates, which allowed for the possibility of detection of a particular fish at more than one downstream site (Marsh et al. 1999).

For fish released in the Snake River Basin, we used the records of downstream PIT-tag detections in the SR Model to estimate survival from the point of release to Lower Granite Dam tailrace, from Lower Granite Dam tailrace to Little Goose Dam tailrace, from Little Goose Dam tailrace to Lower Monumental Dam tailrace, from Lower Monumental Dam tailrace to McNary Dam tailrace, from McNary Dam tailrace to John Day Dam tailrace, and from John Day Dam tailrace to Bonneville Dam tailrace. For fish 
released in the Upper Columbia River, we estimated survival from the point of release to the tailrace of McNary Dam, from McNary Dam tailrace to John Day Dam tailrace, and from John Day Dam tailrace to Bonneville Dam tailrace.

\section{Lower Granite Dam Tailrace Release Groups}

During 2003, hatchery steelhead were collected at the Lower Granite Dam juvenile facility, PIT tagged, and released in approximate proportion to their arrival at Lower Granite Dam throughout the migration season. No yearling chinook salmon or wild steelhead were PIT tagged specifically for this study because the numbers of fish PIT tagged and released from Snake River Basin hatcheries, traps, and at Lower Granite Dam for other studies were sufficient for analysis.

For both yearling chinook salmon and steelhead tagged above Lower Granite Dam and subsequently detected at Lower Granite Dam and released to the tailrace, we created daily "release groups" by combining detections at Lower Granite Dam that occurred on the same day. For steelhead, these groups were then combined with hatchery fish tagged and released each day at Lower Granite Dam. These daily release groups were then pooled into weekly groups, and we estimated survival probabilities in the reaches between Lower Granite Dam tailrace and McNary Dam tailrace for both the daily and weekly groups.

\section{McNary Dam Tailrace Release Groups}

For both yearling chinook salmon and steelhead tagged at all locations in the Snake River Basin, and for fish tagged in the Upper Columbia River, we created daily "release groups" of fish according to the day of detection at McNary Dam. Daily groups consisted of fish that were detected and returned to the tailrace, and daily groups were pooled into weekly groups. For weekly groups leaving McNary Dam, we estimated survival from McNary Dam tailrace to John Day Dam tailrace and from John Day Dam tailrace to Bonneville Dam tailrace.

\section{Hatchery and Trap Release Groups}

In 2003, most hatcheries in the Snake River Basin released PIT-tagged fish as part of research separate from the NMFS/UW survival study. We analyzed data from hatchery releases of PIT-tagged yearling chinook salmon, sockeye salmon, coho salmon, and steelhead to provide estimates of survival and detection probabilities from release to the tailrace of Lower Granite Dam and to points downstream. We also estimated survival 
from release to the tailrace of McNary Dam for yearling spring chinook salmon released from Winthrop, Entiat, Leavenworth, and Methow hatcheries and steelhead from Wells, Chelan, East Bank, Ringold, and Winthrop hatcheries in the Upper Columbia River Basin. In the course of characterizing the various hatchery releases, preliminary analyses were performed to determine whether data from multiple release groups could be pooled to increase sample sizes. We neither intended nor attempted to analyze the experiments for which the hatchery groups were released.

We also estimated survival for releases of wild and hatchery PIT-tagged yearling chinook salmon and steelhead from the Salmon (White Bird), Snake, and Clearwater River traps, and many more smolt traps throughout the Snake River Basin to Lower Granite Dam tailrace and points downstream.

Survival was also estimated for releases of yearling summer/fall chinook salmon from four Upper and Mid Columbia River dams to the tailrace of McNary Dam and to points downstream.

\section{Data Analysis}

Tagging and detection data were uploaded to and later retrieved from the PIT Tag Information System (PTAGIS), a regional database maintained by the Pacific States Marine Fisheries Commission (PSMFC 2003). Data were examined for erroneous records, inconsistencies, and data anomalies. Records were eliminated where appropriate, and all eliminated PIT-tag codes were recorded with the reasons for their elimination. For each remaining PIT-tag code, we constructed a record ("detection history") indicating at which sites the tagged fish was detected and at which it was not detected. Methods for data retrieval, database quality assurance/control, and construction of detection histories were the same as those used in past years (see Iwamoto et al. 1994 for detail).

These analyses were conducted with currently available data. It is possible, for a variety of reasons, that the data in the PTAGIS database may be updated. Thus, estimates provided by NMFS or employed in analyses in the future may differ slightly from those presented here. 


\section{Tests of Assumptions}

As in past years, we evaluated assumptions of the SR Model as applied to the data generated from PIT-tagged juvenile salmonids in the Snake and Columbia Rivers (Burnham et al. 1987).

\section{Survival Estimation}

Estimates of survival probabilities under the SR Model are random variables, subject to sampling variability. When true survival probabilities are close to $1.0 \mathrm{and} /$ or when sampling variability is high, it is possible for estimates of survival probabilities to exceed 1.0. For practical purposes, estimates should be considered equal to 1.0 in these cases.

When estimates for a particular river section or passage route were available from more than one release group, the estimates were often combined using a weighted average (Muir et al. 2001a). Weights were inversely proportional to the respective estimated relative variance (coefficient of variation squared). The variance of an estimated survival probability from the SR Model is a function of the estimate itself. Consequently, lower survival estimates tend to have smaller estimated variance. Therefore, we did not use the inverse estimated absolute variance in weighting because lower survival estimates would have had disproportionate influence, and the resulting weighted mean would have been biased toward the lower survival estimates.

All survival estimates presented are from point of release (or the tailrace of a dam) to the tailrace of a dam downstream. All survival and detection probability estimates were computed using the statistical computer program SURPH ("Survival with Proportional Hazards") for analyzing release-recapture data, developed at the University of Washington (Skalski et al. 1993; Smith et al. 1994).

\section{Survival Estimates from Point of Release to Bonneville Dam}

We estimated survival from point of release to the tailrace of Bonneville Dam (the last dam encountered by seaward-migrating juvenile salmonids) for various stocks from both the Snake and Upper Columbia Rivers. These estimates were obtained by first calculating weighted average estimated survival over shorter reaches for daily or weekly release groups using the same weighting scheme described above. These average survival estimates were then multiplied to estimate the survival probability through the entire reach. 
We pooled similar fish from different release sites when we re-formed release groups at downstream sites. For example, for Snake River yearling chinook salmon and steelhead, we multiplied the weighted mean survival estimate for daily groups from Lower Granite to McNary Dam tailrace by the weighted mean estimate for weekly groups from McNary to Bonneville Dam tailrace to obtain an overall estimated mean probability of survival from Lower Granite to Bonneville Dam tailrace. Finally, we multiplied this result by the survival estimate from fish released from the Snake River trap to Lower Granite Dam to compute estimated survival from the head of Lower Granite Reservoir to the tailrace of Bonneville Dam; essentially the entire eight-project hydropower system negotiated by juvenile salmonids from the Snake River Basin.

\section{Travel Time and Migration Rate}

Travel times were calculated for yearling chinook salmon and steelhead from:

1) Lower Granite Dam to Little Goose Dam (60 km),

2) Little Goose Dam to Lower Monumental Dam (46 km),

3) Lower Monumental Dam to McNary Dam (199 km),

4) Lower Granite Dam to McNary Dam (225 km),

5) Lower Granite Dam to Bonneville Dam (461 km),

6) McNary Dam to John Day Dam (123 km),

7) John Day Dam to Bonneville Dam $(113 \mathrm{~km})$, and

8) McNary Dam to Bonneville Dam $(236 \mathrm{~km})$.

Travel time between any two dams was calculated for each fish detected at both dams as the number of days between last detection at the upstream dam (generally at a PIT-tag detector close enough to the outfall site that fish arrived in the tailrace within minutes after detection) and first detection at the downstream dam. Travel time included the time required to move through the reservoir to the forebay of the downstream dam and any delay associated with residence in the forebay, gatewells, or collection channel prior to detection in the juvenile bypass system.

Migration rate through a river section was calculated as the length of the section $(\mathrm{km})$ divided by the travel time (days) (which included any delay at dams as noted above). For each group, the 20th percentile, median, and 80th percentile travel times and migration rates were determined.

The true complete set of travel times for a release group includes travel times of both detected and nondetected fish. However, using PIT tags, travel times cannot be 
determined for a fish that traverses a river section but is not detected at both ends of the section. Travel time statistics are computed only from travel times for detected fish, which represent a sample of the complete set. Nondetected fish pass dams via turbines and spill; thus, their time to pass a dam is typically minutes to hours shorter than detected fish passing to the tailrace via the juvenile bypass system.

\section{Comparison of Annual Survival Estimates}

We made two comparisons of 2003 results to those obtained in previous years of the NMFS/UW survival study. First, we related survival estimates from specific hatcheries to Lower Granite Dam to migration distance. Second, we compared season-wide survival estimates for specific reaches across years.

\section{Flow and Spill In Relation to Juvenile Salmonid Survival and Travel Time}

Annual travel time and reach survival estimates were compared across years to investigate relationships with general flow and spill conditions during the spring migration. Trends within the 2003 season are also discussed. 


\section{RESULTS}

\section{Lower Granite Dam Tagging and Release Information}

Between 23 March and 31 May, 2003, a total of 69,802 yearling chinook salmon (22,958 hatchery origin, 46,844 wild) were detected and released or PIT tagged and released to the tailrace of Lower Granite Dam. Steelhead we tagged at Lower Granite Dam and released to the tailrace were combined with those that were released upstream, detected at the dam, and returned to the river, for a total of $60,057(24,556$ hatchery origin, 35,501 wild) between 26 March and 7 June, 2003. The proportion of wild fish used for survival estimation in 2003 was higher than in past years.

For both species, not all detections were included in the analyses because some fish passed Lower Granite Dam early or late in the season, when sample sizes were too small to produce reliable survival or travel time estimates. Survival estimates for wild

and hatchery fish combined were predominately based on fish of wild origin for yearling chinook salmon (67\% wild) and steelhead (59\% wild) during 2003.

\section{Survival Estimation}

\section{Tests of Assumptions}

Assumption tests for 2003 indicated a few more significant results than would be expected by chance alone. We present a detailed discussion of the assumption tests, the extent of their violations, possible reasons for the occurrence of the violations, and the implications in the Appendix.

\section{Snake River Yearling Chinook Salmon}

Survival probabilities for weekly groups of yearling chinook salmon released to the tailrace of Lower Granite Dam were estimated for 13 consecutive weeks from 30 March through 28 June (Table 1). Survival estimates from Lower Granite to Little Goose Dam tailrace averaged 0.946 (s.e. 0.005). From Little Goose to Lower Monumental Dam tailrace, estimated survival averaged 0.916 (s.e. 0.011). From Lower Monumental to McNary Dam tailrace, estimated survival averaged 0.904 (s.e. 0.017). For the combined reach from Lower Granite Dam tailrace to McNary Dam tailrace, survival averaged 0.731 (s.e. 0.010). 
We estimated survival probabilities for weekly groups of yearling chinook salmon released in the tailrace at McNary Dam for seven consecutive weeks from 20 April through 7 June. From McNary Dam tailrace to John Day Dam tailrace, estimated survival averaged 0.893 (s.e. 0.017; Table 2). From John Day Dam tailrace to Bonneville Dam tailrace estimated survival averaged 0.818 (s.e. 0.036). For the combined reach from McNary Dam to Bonneville Dam, estimated survival averaged 0.728 (s.e. 0.030).

The product of the average estimates from Lower Granite Dam to McNary Dam and from McNary Dam to Bonneville Dam provided an overall survival estimate from Lower Granite Dam tailrace to Bonneville Dam tailrace of 0.532 (s.e. 0.023). Estimated survival probability through Lower Granite Reservoir and Dam for Snake River wild and hatchery chinook salmon released from the Snake River trap was 0.993 (s.e. 0.023). Thus, estimated survival probability through all eight hydrosystem projects encountered by Snake River yearling chinook salmon was 0.528 (0.023).

We also calculated separate survival probability estimates for weekly groups of hatchery and wild yearling chinook salmon from Lower Granite Dam tailrace to McNary Dam tailrace (Tables 3 and 4). Weighted mean survival estimates for wild yearling chinook salmon were slightly lower than for hatchery fish for the combined reach from the tailrace of Lower Granite Dam to the tailrace of McNary Dam in 2003.

Estimated survival probabilities for daily Lower Granite Dam release groups of yearling chinook salmon (hatchery and wild combined) detected and released to the tailrace of Lower Granite Dam did not show any consistent increase or decrease through the migration season during 2003 (Table 5, Fig. 2).

Estimates of detection probability at Snake River dams for the weekly groups varied throughout the season, primarily because of varying levels of spill (Tables 6-9).

\section{Snake River Steelhead}

For weekly groups of steelhead released in the tailrace of Lower Granite Dam we estimated survival probabilities for 10 consecutive weeks from 30 March through 7 June (Table 10). Survival estimates from Lower Granite to Little Goose Dam tailrace averaged 0.947 (s.e. 0.005). From Little Goose to Lower Monumental Dam tailrace, estimated survival averaged 0.898 (s.e. 0.012). From Lower Monumental to McNary Dam tailrace, estimated survival averaged 0.708 (s.e. 0.018). For the combined reach from Lower Granite Dam tailrace to McNary Dam tailrace, survival averaged 0.597 (s.e. 0.013). 
We estimated survival probabilities for weekly groups of steelhead released in the tailrace of McNary Dam for six consecutive weeks from 27 April through 7 June. From McNary to John Day Dam tailrace, estimated survival averaged 0.879 (s.e. 0.032;

Table 11). From John Day to Bonneville Dam tailrace estimated survival averaged 0.630 (s.e. 0.066). For the combined reach from McNary Dam to Bonneville Dam, estimated survival averaged 0.518 (s.e. 0.015 ).

The product of the average estimates from Lower Granite to McNary Dam and from McNary to Bonneville Dam provided an overall average survival estimate from Lower Granite Dam tailrace to Bonneville Dam tailrace of 0.309 (s.e. 0.011). The estimated survival through Lower Granite Reservoir and Dam for Snake River wild and hatchery steelhead released from the Snake River trap was 0.932 (s.e. 0.015). Thus, the estimated survival probability through all eight of the hydrosystem projects encountered by Snake River steelhead was 0.288 (s.e. 0.011).

Survival probabilities were estimated separately for weekly groups of hatchery and wild steelhead from Lower Granite Dam tailrace to McNary Dam tailrace (Tables 12 and 13). Survival estimates for wild and hatchery steelhead through most reaches were similar.

Estimated survival probabilities from Lower Monumental to McNary Dam (and hence for the overall reach from Lower Granite to McNary Dam) tended to decrease as the season progressed for daily release groups of steelhead (hatchery and wild combined) detected and released, or PIT tagged and released to the tailrace of Lower Granite Dam (Table 14, Fig. 3). Detection probability estimates for the daily and weekly groups varied throughout the season, primarily because of varying levels of spill (Tables 15-18).

\section{Snake River Hatchery Release Groups}

Estimated survival probabilities of PIT-tagged hatchery yearling chinook salmon, sockeye salmon, coho salmon, and steelhead from release at Snake River Basin hatcheries to the tailrace of Lower Granite Dam and downstream dams varied among hatcheries and release locations (Tables 19-21), as did estimated detection probabilities at the detection sites (Tables 22-24). 


\section{Snake River Smolt Trap Release Groups}

Survival probability estimates for juvenile salmonids PIT tagged and released from Snake River Basin smolt traps were generally inversely related to distance of the traps to Lower Granite Dam (Table 25). Estimated detection probabilities were similar among release groups of the same species from different traps (Table 26).

\section{Upper Columbia River Hatchery Release Groups}

Survival probabilities of PIT-tagged hatchery yearling chinook salmon and steelhead from release at Upper Columbia River hatcheries to the tailrace of McNary Dam varied among hatcheries, with survival decreasing with increasing distance upstream (Table 27). Detection probabilities at downstream dams were similar for yearling chinook salmon and steelhead from all hatcheries (Table 28).

\section{Travel Time and Migration Rate}

Travel time estimates for yearling chinook salmon and juvenile steelhead released in the tailraces of Lower Granite and McNary Dams varied throughout the season (Tables 29-36). For both species, migration rates were generally highest in the lower river sections. Migration rates generally increased over time as flow and water temperature increased, and, presumably, as fish became more smolted (Fig. 4). Travel time for yearling chinook salmon from Lower Monumental to McNary Dam decreased during April independent of flow while travel time for steelhead was more flow-dependent (Fig. 5).

\section{Tagging Details for Hatchery Steelhead PIT Tagged at Lower Granite Dam}

We tagged 19,840 hatchery steelhead from 9 April through 7 June at Lower Granite Dam for survival estimates (Table 37). There were 25 mortalities, representing less than $1 \%$ of the total handled. 


\section{Comparison of Annual Survival Estimates}

Estimates of survival from Snake River Basin hatcheries to Lower Granite Dam tailrace for 2003 were similar to or higher than those made in past years (Table 38). Over the years of the study, we have consistently observed an inverse relationship between the migration distance from the release site to Lower Granite Dam and the estimated survival through that reach (Fig. 6). For 1993-2003 estimates, the negative linear correlation between migration distance and estimated survival was significant $\left(\mathrm{R}^{2}=0.941\right.$, $P<0.0001)$.

For yearling chinook salmon, estimated survival in 2003 was similar to or slightly higher than that estimated in previous years through all reaches (Table 39; Figs. 7-8). For steelhead, survival estimates in 2003 were similar to those from previous years through all reaches except that they remained depressed through the Lower Monumental Dam to McNary Dam and John Day Dam to Bonneville Dam reaches (Table 40; Figs. 7-8).

For yearling chinook salmon, mean survival for all years combined was similar through each of the Snake River reaches (0.90-0.92) and similar but lower through Columbia River reaches (0.85-0.87; Table 39). For steelhead, mean survival across years showed a slight decline through successive reaches, and was lowest through the McNary to John Day reach (0.78), the reach with the longest reservoir (Table 40). Omitting estimates from 2001, average survival estimates for steelhead are more similar to those for yearling chinook salmon.

For several years, we have combined empirical survival estimates from various reaches for Snake River yearling chinook salmon (data were sufficient starting in 1999) and steelhead (starting in 1997) to calculate estimates throughout the entire hydropower system. Survival estimates from the head of Lower Granite Reservoir (Snake River smolt trap) to the tailrace of Bonneville Dam are shown in Table 41.

\section{Flow and Spill In Relation to Juvenile Salmonid Survival and Travel Time}

Snake River flow volume during the yearling chinook salmon migration period was expressed as flow exposure at Lower Monumental Dam for each release group. Average flow exposure during 2003 (93.5 kcfs) was much greater than during 2002 (77.6 kcfs) and 2001 (70.0 kcfs) (Fig. 9). However, because of the relatively cool spring, flow volume during the majority of the 2003 yearling chinook salmon migration period was similar to flow volume during 2002 , and only slightly greater than in 2001 , which 
was the lowest recorded during the eleven years of this study. Late in the migration season flows were much greater than the previous two years, which increased the average flow exposure, but the majority of yearling chinook salmon had already migrated out of the Snake River by then.

Because steelhead migrate later in the spring, a larger portion of them migrated during in the greater flow volume that occurred later in the migration season. Average flow exposure for steelhead during 2003 was $117.4 \mathrm{kcfs}$, compared to $91.7 \mathrm{kcfs}$ in 2002 , and $70.0 \mathrm{kcfs}$ in 2001 (Fig.10).

Spill was provided during spring 2003 at all dams at levels similar to recent years, excluding 2001 when spill was eliminated at some projects (Lower Granite, Little Goose, and Lower Monumental Dams) and limited in volume and duration at others (Ice Harbor, McNary, John Day, and Bonneville Dams).

Comparing travel times of yearling chinook salmon and steelhead among years, 2003 travel times between Lower Granite and Bonneville Dams were similar to past years during most of the migration, and much shorter than those observed during 2001 (Fig. 4).

Through most reaches, estimated survival of yearling chinook salmon in 2003 was similar to estimated survival in other recent years and substantially greater than in 2001 (Figs. 7-8; Table 39). For steelhead, survival estimates in 2003 were slightly greater than in 2002 in all reaches, and much improved compared to 2001. However, survival remained depressed relative to earlier years in the reach from Lower Monumental to McNary Dam and perhaps the reach from John Day to Bonneville Dam, although the survival estimate in this last reach had high variance (Figs. 7-8; Table 40).

\section{Survival Estimates from Point of Release to Bonneville Dam}

Yearling spring/summer chinook salmon from Lower Granite Dam on the Snake River and yearling summer/fall chinook salmon from Rocky Reach Dam on the upper Columbia River each migrated past seven projects to the tailrace of Bonneville Dam. Their estimated survival probabilities were similar at $0.532(0.023)$ for the Snake River stock and 0.550 (0.057) for the Upper Columbia River stock (Table 42). Survival increased for summer/fall chinook released from upper Columbia River dams downstream from Rocky Reach Dam. Estimated survival of yearling spring chinook salmon released at hatcheries in the Upper Columbia River was similar to that of their Snake River counterparts in 2003, but greater than observed for them in 2002 (Tables 19 
and 27). In 2003, average survival estimates were 0.569 (0.024) for fish released at Leavenworth Hatchery (seven projects and $800 \mathrm{~km}$ upstream) and 0.559 (0.049) for fish released at Entiat Hatchery (eight projects and $795 \mathrm{~km}$ upstream) in the upper Columbia River compared to 0.581 (0.009) for fish released from Dworshak Hatchery (eight projects and $811 \mathrm{~km}$ upstream) in the Snake River.

Steelhead released in the Chiwawa River from East Bank Hatchery had higher estimated survival to Bonneville Dam tailrace than did their counterparts from Dworshak Hatchery in the Snake River Basin (Tables 20 and 27). For steelhead released from all other Upper Columbia hatcheries and passing a similar number of dams, estimated survival to Bonneville Dam was lower than for steelhead from Dworshak hatchery. 


\section{DISCUSSION}

Flow volume during most of the 2003 spring migration of yearling chinook salmon was similar to 2002 and only slightly greater than the drought conditions of 2001, although flow volumes were much higher for the latter part of the migration in 2003. Spill occurred at levels similar to other recent years excluding 2001. Survival for yearling chinook salmon through the entire hydropower system in 2003 was similar to other recent years and much higher than in 2001. This is consistent with early findings supporting positive effects of spill on survival on a season-wide basis. Analyses based on data from 1973 to 1979 suggested that increases in spill had a direct impact on increasing survival (Sims and Ossiander 1981). From our own research, estimated survival through the hydropower system was lower in 1993 and 1994, when spill occurred only in excess of powerhouse capacity, than it was after spill at all dams was prescribed in the 1995 Biological Opinion (NMFS 1995). Demonstrating in-season effects of spill has been more problematic (Smith et al. 2002; Zabel et al. 2002).

For steelhead, survival in 2003 increased slightly in all reaches compared to 2002 and was substantially higher over that observed during 2001. However, survival remained depressed compared to other recent years, particularly in the Lower Monumental to McNary Dam reach and perhaps the John Day to Bonneville Dam reach. Avian predation appears to have decreased survival of steelhead. Steelhead are particularly susceptible to predation by birds: Collis et al. (2001) found that greater than $15 \%$ of the tags from PIT-tagged steelhead entering the Columbia River estuary in 1998 were later found on estuarine bird colonies, while only $2 \%$ of tags from PIT-tagged yearling chinook salmon were found on colonies. In 1998 the major site of tag recovery was Rice Island, which was then home to the largest Caspian tern (Sterna caspia) colony in North America. Ryan et al. (2002, 2003) and Glabek et al. (2003) reported similar results in subsequent years, as the tern colony was relocated from Rice Island to East Sand Island.

Crescent Island in the McNary Dam reservoir harbors the second largest Caspian tern colony in North America (>600 individuals) and large populations of gulls $(>39,000)$ (Larus spp.). Other avian piscivores that reside at other locations within McNary pool include American white pelicans (Pelecanus erythrorhynchos), cormorants (Phalacrocorax auritus), and herons (Ardea alba, A. herodias, and Nycticorax nycticorax) (Collis et al. 2002). During 2003, although only Crescent Island was sampled, 3.7\% of the PIT tags from steelhead detected at Lower Monumental Dam were found there (Table 43). This percentage would increase to an unknown degree had the 
other bird colonies been sampled in 2003, although in past years, Crescent Island accounted for the majority (about 70\%) of PIT tags found in McNary Pool (B. Ryan, NMFS, personal communication). Although the percentage of PIT-tagged steelhead detected on Crescent Island in 2003 was lower than the past two years, it still represents a substantial loss. In other years, additional PIT tags (mostly steelhead) have been detected on gull colonies in the John Day and The Dalles reservoirs as well (Glabek et al. 2003, Ryan et al. 2002).

Tag-detection percentage on avian colonies is a minimum estimate of loss due to bird predation, because not all tags taken by birds are detected (Collis et al. 2001, Glabek et al. 2003, Ryan et al. 2001). From 1998 to 2003, survival estimates for steelhead in the Lower Monumental to McNary Dam reach (Table 39) correlated strongly $\left(\mathrm{R}^{2}=0.932\right.$, $P<0.01)$ with the percentage of smolts detected on McNary reservoir bird colonies (Table 42). There is also significant correlation for yearling chinook salmon $\left(\mathrm{R}^{2}=0.894\right.$; $P<0.01$ ), although the percentage detected on bird colonies is much lower.

In 2003, estimated per-project survival for steelhead was substantially lower in the reach from Lower Monumental to McNary Dam (two projects, $0.708^{1 / 2}=0.841$ ) than those from Lower Granite to Little Goose Dam (0.947) or Little Goose to Lower Monumental Dam (0.898). Also, estimated per-project survival for steelhead from McNary to John Day Dam (0.879) and from John Day to Bonneville Dam (two projects, $0.630^{1 / 2}=0.794$ ) was lower than estimated per-project survival above Lower Monumental Dam. In contrast, $1.1 \%$ of the yearling chinook salmon detected at Lower Monumental Dam were subsequently detected on Crescent Island and the per-project survival estimates for the reaches directly above and below McNary Dam were not substantially different than in other reaches.

Lacking a PIT-tag detection system at Ice Harbor Dam, we are currently unable to estimate project-specific survival between Lower Monumental and McNary. However, there have been studies to estimate spillway and project survival using both PIT tags and radio telemetry. Using radio tags, survival of yearling chinook salmon passing through the spillway at Ice Harbor Dam was estimated in 2003 at 0.928 at $50 \%$ spill and 0.948 at spill levels recommended in the NMFS Biological Opinion ("BiOp spill level") (NMFS 2000). At BiOp spill levels in 2002 and 2000, spillway survival was estimated at 0.892 and 0.978 , respectively (B. Eppard, NMFS, personal communication). Ice Harbor Dam project survival in 2003 was estimated at 0.937 at BiOp spill level and 0.919 at $50 \%$ spill. In 2001, survival of PIT-tagged yearling chinook salmon from $5 \mathrm{~km}$ upstream from Ice Harbor Dam to McNary Dam tailrace was estimated at 0.724 (Axel et al. 2003). Spillway and project survival has not been estimated for steelhead at Ice Harbor Dam. Operational 
changes at Lower Monumental or Ice Harbor Dam, including spill levels and spill patterns, could influence vulnerability of steelhead to avian predators. In addition, tailwater elevation at Ice Harbor Dam could influence spillway survival via the effects of spillbay deflectors installed prior to the 1998 migration.

Proportions of PIT-tagged fish (especially steelhead) taken by avian predators have increased in the last several years, with a corresponding decrease in survival. It is unlikely the change is due to increased predator abundance since the Caspian tern colony has not increased in size during this time period (Glabek et al. 2003). Therefore, a change in either the susceptibility of smolts to avian predators or to the system operations is the likely cause. Research to elucidate the complicated dynamics of this predator-prey system is ongoing. In particular, we need more fine partitioning of survival estimates in the reach between Lower Monumental and McNary Dams, and we need a better understanding of tern behavior.

Results from the 2003 studies provide estimates of survival only during the downstream portion of the migration. We will analyze these data in conjunction with adult returns over the next three years to determine whether variations in spill, flow, temperature, and passage route produce patterns in smolt-to-adult survival consistent with those observed during the downstream migration phase. 


\section{RECOMMENDATIONS}

1) Coordination of future survival studies with other projects should continue to maximize the data-collection effort and minimize study effects on salmonid resources.

2) To date, little mortality has been found in Lower Granite reservoir and most other reservoirs investigated. However, although lower than the last two years, considerable steelhead mortality was observed in 2003 in the river reach between Lower Monumental and McNary Dams. Avian predators may cause this mortality, and this issue merits further investigation. Estimates of survival from hatcheries to Lower Granite Dam suggest that substantial mortality occurs upstream from the Snake and Clearwater River confluence. Efforts should continue to identify where this mortality occurs.

3) Increasing the number of detection facilities in the Columbia River Basin will improve survival investigations. We recommend installation of detectors and diversion systems at Ice Harbor, The Dalles, and Upper Columbia River dams. The development of flat-plate and full-flow detector technology in bypass systems and other suitable locations at dams will greatly enhance survival estimation capabilities, as will portable streambed flat-plate detectors for use in tributaries.

\section{ACKNOWLEDGMENTS}

We express our appreciation to all who assisted with this research. C. Stein and staff of the Pacific States Marine Fisheries Commission provided valuable assistance in data acquisition. Fish Ecology Division staff from several research stations participated in the study. T. Ruehle, S. Davidson, and other staff at the Pasco Field Station coordinated much of the planning and operational elements and minimized potential logistical problems. B. Ryan and B. Sandford provided PIT tag data from avian bird colonies. Support for this research came from the region's electrical ratepayers through the Bonneville Power Administration and the National Marine Fisheries Service. 


\section{REFERENCES}

Axel, G. A., E. E. Hockersmith, M. B. Eppard, B. P. Sandford, S. G. Smith, and D. B. Dey. 2003. Passage behavior and survival of hatchery yearling chinook salmon passing Ice Harbor and McNary Dams during a low flow year, 2001. Report of the National Marine Fisheries Service to the U.S. Army Corps of Engineers, Walla Walla, Washington.

Burnham, K. P., D. R. Anderson, G. C. White, C. Brownie, and K. H. Pollock. 1987. Design and analysis methods for fish survival experiments based on release-recapture. American Fisheries Society Monograph 5:1-437.

Collis, K. D., D. D. Roby, D. P. Craig, S. Adamany, J. Y. Adkins, and D. E. Lyons. 2002. Colony size and diet composition of piscivorous waterbirds on the lower Columbia River: Implications for losses of juvenile salmonids to avian predation. Transactions of the American Fisheries Society 131:537-550.

Collis, K., D. D. Roby, D. P. Craig, B. R. Ryan, and R. D. Ledgerwood. 2001. Colonial waterbird predation on juvenile salmonids tagged with passive integrated transponders in the Columbia River Estuary: Vulnerability of different salmonid species, stocks, and rearing types. Transactions of the American Fisheries Society 130:385-396.

Cormack, R. M. 1964. Estimates of survival from the sightings of marked animals. Biometrika 51:429-438.

Glabek, J. H., B. A. Ryan, E. P. Nunnallee, and J. W. Ferguson. 2003. Detection of passive integrated transponder (PIT) tags on piscivorous bird colonies in the Columbia River Basin, 2001. Report of the National Marine Fisheries Service to the U.S. Army Corps of Engineers, Walla Walla, Washington.

Hockersmith, E. E., S. G. Smith, W. D. Muir, B. P. Sandford, J. G. Williams, and J. R. Skalski. 1999. Survival estimates for the passage of juvenile salmonids through Snake River dams and reservoirs, 1997. Report of the National Marine Fisheries Service to the Bonneville Power Administration, Portland, Oregon. 
Iwamoto, R. N., W. D. Muir, B. P. Sandford, K. W. McIntyre, D. A. Frost, J. G. Williams, S. G. Smith, and J. R. Skalski. 1994. Survival estimates for the passage of juvenile chinook salmon through Snake River dams and reservoirs, 1993. Report of the National Marine Fisheries Service to the Bonneville Power Administration, , Portland, Oregon.

Jolly, G. M. 1965. Explicit estimates from capture-recapture data with both death and Immigration--stochastic model. Biometrika 52:225-247.

Ledgerwood, R. D., B. A. Ryan, E. M. Dawley, E. P. Nunnallee, and J. W. Ferguson. In press. A surface trawl to detect juvenile salmonids tagged with passive integrated transponder tags. North American Journal of Fisheries Management.

Marsh, D. M., G. M. Matthews, S. Achord, T. E. Ruehle, and B. P. Sandford. 1999. Diversion of salmonid smolts tagged with passive integrated transponders from an untagged population passing through a juvenile collection system. North American Journal of Fisheries Management 19:1142-1146.

Muir, W. D., S. G. Smith, E. E. Hockersmith, S. Achord, R. F. Absolon, P. A. Ocker, B. M. Eppard, T. E. Ruehle, J. G. Williams, R. N. Iwamoto, and J. R. Skalski. 1996. Survival estimates for the passage of yearling chinook salmon and steelhead through Snake River dams and reservoirs, 1995. Report of the National Marine Fisheries Service to the Bonneville Power Administration, Portland, Oregon.

Muir, W. D., S. G. Smith, R. N. Iwamoto, D. J. Kamikawa, K. W. McIntyre, E. E. Hockersmith, B. P. Sandford, P. A. Ocker, T. E. Ruehle, J. G. Williams, and J. R. Skalski. 1995. Survival estimates for the passage of juvenile salmonids through Snake River dams and reservoirs, 1994. Report of the National Marine Fisheries Service to the Bonneville Power Administration, Portland, Oregon.

Muir, W. D., S. G. Smith, J. G. Williams, E. E. Hockersmith, and J. R. Skalski. 2001a. Survival estimates for migrant yearling chinook salmon and steelhead tagged with passive integrated transponders in the Lower Snake and Columbia Rivers, 1993-1998. North American Journal of Fisheries Management 21:269-282.

Muir, W. D., S. G. Smith, J. G. Williams, and B. P. Sandford. 2001b. Survival of juvenile salmonids passing through bypass systems, turbines, and spillways with and without flow deflectors at Snake River Dams. North American Journal of Fisheries Management 21:135-146. 
Muir, W. D., S. G. Smith, R. W. Zabel, D M. Marsh, J. G. Williams, and J. R. Skalski. 2003. Survival estimates for the passage of spring-migrating juvenile salmonids through Snake and Columbia River dams and reservoirs, 2002. Report of the National Marine Fisheries Service to the Bonneville Power Administration, Portland, Oregon.

NMFS (National Marine Fisheries Service). 2000. Endangered Species Act, Section 7 Consultation, Biological Opinion: Reinitiation of consultation on operation of the Federal Columbia River power system, including the juvenile fish transportation program and 19 Bureau of Reclamation projects in the Columbia Basin. (Available from internet at http://www.nwr.noaa.gov/1hydrop/hydroweb/docs/Final/2000Biop.html.)

Prentice, E. F., T. A. Flagg, and C. S. McCutcheon. 1990a. Feasibility of using implantable passive integrated transponder (PIT) tags in salmonids. American Fisheries Society Symposium 7:317-322.

Prentice, E. F., T. A. Flagg, C. S. McCutcheon, and D. F. Brastow. 1990b. PIT-tag monitoring systems for hydroelectric dams and fish hatcheries. American Fisheries Society Symposium 7:323-334.

Prentice, E. F., T. A. Flagg, C. S. McCutcheon, D. F. Brastow, and D. C. Cross. 1990c. Equipment, methods, and an automated data-entry station for PIT tagging. American Fisheries Society Symposium 7:335-340.

PSMFC (Pacific States Marine Fisheries Commission). 2003. The Columbia Basin PIT Tag Information System (PTAGIS). PSMFC, Gladstone, Oregon. Online database available through the internet at http://www.psmfc.org.pittag/ (accessed 29 August 2003).

Raymond, H. L. 1979. Effects of dams and impoundments on migrations of juvenile chinook salmon and steelhead from the Snake River, 1966 to 1975. Transactions of the American Fisheries Society 108(6):505-529.

Ryan, B. A., J. W. Ferguson, R. D. Ledgerwood, and E. P. Nunnallee. 2001. Detection of passive integrated transponder tags from juvenile salmonids on piscivorous bird colonies in the Columbia River Basin. North American Journal of Fisheries Management 21:417-421. 
Ryan, B. A., J. H. Glabek, J. W. Ferguson, E. P. Nunnallee, and R. D. Ledgerwood. 2002. Detection of passive integrated transponder (PIT) tags on piscivorous bird colonies in the Columbia River Basin, 2000. Report of the National Marine Fisheries Service to the U.S. Army Corps of Engineers, Walla Walla, Washington.

Ryan, B. A., S. G. Smith, J. M. Butzerin, and J. W. Ferguson. 2003. Relative vulnerability to avian predation of juvenile salmonids tagged with passive integrated transponders in the Columbia River estuary, 1998-2000. Transactions of the American Fisheries Society 132:275-288.

Seber, G. A. F. 1965. A note on the multiple recapture census. Biometrika 52:249-259.

Sims, C., and F. Ossiander. 1981. Migrations of juvenile chinook salmon and steelhead in the Snake River, from 1973 to 1979, a research summary. Report of the National Marine Fisheries Service to the U.S. Army Corps of Engineers.

Skalski, J. R. 1998. Estimating season-wide survival rates of outmigrating salmon smolt in the Snake River, Washington. Canadian Journal of Fisheries and Aquatic Sciences 55:761-769.

Skalski, J. R., A. Hoffmann, and S. G. Smith. 1993. Testing the significance of individual and cohort-level covariates in animal survival studies. Pages 1-17 In J. D. Lebreton and P. M. North (editors), The use of marked individuals in the study of bird population dynamics: Models, methods, and software. Birkhauser Verlag, Basel.

Skalski, J. R., S. G. Smith, R. N. Iwamoto, J. G. Williams, and A. Hoffmann. 1998. Use of passive integrated transponder tags to estimate survival of migrant juvenile salmonids in the Snake and Columbia Rivers. Canadian Journal of Fisheries and Aquatic Sciences 55:1484-1493.

Smith, S. G., W. D. Muir, S. Achord, E. E. Hockersmith, B. P. Sandford, J. G. Williams, and J. R. Skalski. 2000a. Survival estimates for the passage of juvenile salmonids through Snake and Columbia River dams and reservoirs, 1998. Report of the National Marine Fisheries Service to the Bonneville Power Administration, Portland, Oregon. 
Smith, S. G., W. D. Muir, G. Axel, R. W. Zabel, J. G. Williams, and J. R. Skalski. 2000b. Survival estimates for the passage of juvenile salmonids through Snake and Columbia River dams and reservoirs, 1999. Report of the National Marine Fisheries Service to the Bonneville Power Administration, Portland, Oregon.

Smith, S. G., W. D. Muir, E. E. Hockersmith, S. Achord, M. B. Eppard, T. E. Ruehle, J. G. Williams, and J. R. Skalski. 1998. Survival estimates for the passage of juvenile salmonids through Snake River dams and reservoirs, 1996. Report of the National Marine Fisheries Service to the Bonneville Power Administration, Portland, Oregon.

Smith, S. G., W. D. Muir, J. G. Williams and J. R. Skalski. 2002. Factors associated with travel time and survival of migrant yearling chinook salmon and steelhead in the lower Snake River. North American Journal of Fisheries Management 22:385-405.

Smith, S. G., J. R. Skalski, W. Schlechte, A. Hoffmann, and V. Cassen. 1994. Statistical survival analysis of fish and wildlife tagging studies. SURPH.1 Manual. (Available from University of Washington, School of Aquatic \& Fisheries Science, 1325 Fourth Avenue, Suite 1820, Seattle, WA 98101-2509.)

Williams, J. G., and G. M. Matthews. 1995. A review of flow survival relationships for spring and summer chinook salmon, Oncorhynchus tshawytscha, from the Snake River Basin. Fish. Bull., U.S. 93:732-740.

Williams, J. G., S. G. Smith, and W. D. Muir. 2001. Survival estimates for downstream migrant yearling juvenile salmonids through the Snake and Columbia Rivers hydropower system, 1996-1980 and 1993-1999. North American Journal of Fisheries Management 21:310-317.

Zabel, R. W., S. G. Smith, W. D. Muir, D. M. Marsh, and J. G. Williams. 2002. Survival estimates for the passage of spring-migrating juvenile salmonids through Snake and Columbia River dams and reservoirs, 2001. Report of the National Marine Fisheries Service to the Bonneville Power Administration, Portland, Oregon. 
Zabel, R. W., S. G. Smith, W. D. Muir, D. M. Marsh, J. G. Williams, and J. R. Skalski. 2001. Survival estimates for the passage of spring-migrating juvenile salmonids through Snake and Columbia River dams and reservoirs, 2000. Report of the National Marine Fisheries Service to the Bonneville Power Administration, Portland, Oregon. 
TABLES 
Table 1. Estimated survival probabilities for Snake River yearling chinook salmon (hatchery and wild combined) detected and released to or PIT tagged and released to the tailrace at Lower Granite Dam in 2003. Daily groups pooled weekly. Estimates based on the Single-Release Model. Standard errors in parentheses. Abbreviations: LGR-Lower Granite Dam; LGO-Little Goose Dam; LMO-Lower Monumental Dam; MCN-McNary Dam.

\begin{tabular}{|c|c|c|c|c|c|}
\hline Date at LGR & $\begin{array}{c}\text { No. } \\
\text { released }\end{array}$ & $\begin{array}{c}\text { LGR } \\
\text { to LGO }\end{array}$ & $\begin{array}{c}\text { LGO } \\
\text { to LMO }\end{array}$ & $\begin{array}{c}\mathrm{LMO} \\
\text { to } \mathrm{MCN}\end{array}$ & $\begin{array}{c}\text { LGR } \\
\text { to } \mathrm{MCN}\end{array}$ \\
\hline 30 Mar-05 Apr & 506 & $0.737(0.054)$ & $0.912(0.124)$ & $0.813(0.115)$ & $0.546(0.047)$ \\
\hline 06 Apr-12 Apr & 1,759 & $0.944(0.041)$ & $0.804(0.085)$ & $0.875(0.088)$ & $0.664(0.033)$ \\
\hline 13 Apr-19 Apr & 6,948 & $0.901(0.016)$ & $0.947(0.048)$ & $0.819(0.043)$ & $0.699(0.017)$ \\
\hline 20 Apr-26 Apr & 13,265 & $0.935(0.015)$ & $0.905(0.044)$ & $0.847(0.041)$ & $0.717(0.014)$ \\
\hline 27 Apr-03 May & 8,429 & $0.960(0.027)$ & $0.833(0.054)$ & $0.840(0.055)$ & $0.671(0.020)$ \\
\hline 04 May-10 May & 12,652 & $0.908(0.021)$ & $0.872(0.042)$ & $0.889(0.041)$ & $0.704(0.016)$ \\
\hline 11 May-17 May & 9,084 & $0.915(0.014)$ & $0.969(0.040)$ & $0.822(0.036)$ & $0.729(0.015)$ \\
\hline 18 May-24 May & 6,810 & $0.959(0.008)$ & $0.935(0.017)$ & $0.900(0.025)$ & $0.807(0.019)$ \\
\hline 25 May-31 May & 10,293 & $0.950(0.008)$ & $0.907(0.019)$ & $0.962(0.028)$ & $0.829(0.020)$ \\
\hline 01 Jun-07 Jun & 3,714 & $0.909(0.014)$ & $0.894(0.032)$ & $0.908(0.048)$ & $0.738(0.033)$ \\
\hline 08 Jun-14 Jun & 462 & $0.933(0.048)$ & $0.885(0.083)$ & $0.799(0.092)$ & $0.660(0.058)$ \\
\hline 15 Jun-21 Jun & 235 & $1.066(0.117)$ & $0.562(0.111)$ & $0.519(0.129)$ & $0.311(0.062)$ \\
\hline 22 Jun-28 Jun & 266 & $0.744(0.050)$ & $0.513(0.077)$ & $0.607(0.117)$ & $0.232(0.041)$ \\
\hline Weighted mean* & & $0.946(0.005)$ & $0.916(0.011)$ & $0.904(0.017)$ & $0.731(0.010)$ \\
\hline
\end{tabular}

* Weighted means of the independent estimates for daily groups (29 March-31 May), with weights inversely proportional to respective estimated relative variances. 
Table 2. Estimated survival probabilities for Snake River yearling chinook salmon (hatchery and wild combined) detected and released to the tailrace at McNary Dam in 2003. Daily groups pooled weekly. Estimates based on the Single-Release Model. Standard errors in parentheses. Abbreviations: MCN-McNary Dam; JDA-John Day Dam; BON-Bonneville Dam.

\begin{tabular}{|c|c|c|c|c|}
\hline Date at $\mathrm{MCN}$ & $\begin{array}{l}\text { Number } \\
\text { released }\end{array}$ & $\begin{array}{c}\mathrm{MCN} \\
\text { to JDA }\end{array}$ & $\begin{array}{c}\text { JDA } \\
\text { to BON }\end{array}$ & $\begin{array}{c}\mathrm{MCN} \\
\text { to } \mathrm{BON}\end{array}$ \\
\hline 20 Apr-26 Apr & 1,463 & $0.880(0.093)$ & $0.904(0.274)$ & $0.795(0.226)$ \\
\hline 27 Apr-03 May & 9,538 & $0.888(0.041)$ & $1.020(0.161)$ & $0.906(0.137)$ \\
\hline 04 May-10 May & 16,748 & $0.867(0.036)$ & $0.767(0.083)$ & $0.665(0.067)$ \\
\hline 11 May-17 May & 19,814 & $0.931(0.031)$ & $0.737(0.072)$ & $0.686(0.063)$ \\
\hline 18 May-24 May & 15,423 & $0.830(0.026)$ & $0.869(0.109)$ & $0.722(0.088)$ \\
\hline 25 May-31 May & 6,172 & $0.921(0.031)$ & $0.835(0.165)$ & $0.769(0.150)$ \\
\hline 01 Jun-07 Jun & 2,188 & $0.953(0.047)$ & $0.827(0.158)$ & $0.788(0.145)$ \\
\hline Weighted mean* & & $0.893(0.017)$ & $0.818(0.036)$ & $0.728(0.030)$ \\
\hline
\end{tabular}

* Weighted means of the independent estimates for weekly pooled groups (20 April - 07 June), with weights inversely proportional to respective estimated relative variances. 
Table 3. Estimated survival probabilities for Snake River hatchery yearling chinook salmon detected and released to the tailrace at Lower Granite Dam in 2003. Daily groups pooled weekly. Estimates based on the Single-Release Model. Standard errors in parentheses. Abbreviations: LGR-Lower Granite Dam; LGO-Little Goose Dam; LMO-Lower Monumental Dam; MCN-McNary Dam.

\begin{tabular}{|c|c|c|c|c|c|}
\hline Date at LGR & $\begin{array}{l}\text { Number } \\
\text { released }\end{array}$ & $\begin{array}{c}\text { LGR } \\
\text { to LGO } \\
\end{array}$ & $\begin{array}{c}\mathrm{LGO} \\
\text { to } \mathrm{LMO}\end{array}$ & $\begin{array}{c}\mathrm{LMO} \\
\text { to } \mathrm{MCN}\end{array}$ & $\begin{array}{c}\mathrm{LGR} \\
\text { to } \mathrm{MCN}\end{array}$ \\
\hline 30 Mar-05 Apr & 280 & $0.610(0.073)$ & $1.310(0.391)$ & $0.571(0.174)$ & $0.456(0.058)$ \\
\hline 06 Apr-12 Apr & 229 & $0.801(0.084)$ & $0.733(0.130)$ & $1.328(0.252)$ & $0.780(0.116)$ \\
\hline 13 Apr-19 Apr & 823 & $0.931(0.051)$ & $1.145(0.183)$ & $0.656(0.111)$ & $0.700(0.053)$ \\
\hline 20 Apr-26 Apr & 3,884 & $0.912(0.028)$ & $0.872(0.069)$ & $0.923(0.076)$ & $0.734(0.028)$ \\
\hline 27 Apr-03 May & 3,842 & $0.925(0.035)$ & $0.785(0.066)$ & $1.040(0.093)$ & $0.755(0.038)$ \\
\hline 04 May-10 May & 5,650 & $0.914(0.033)$ & $0.853(0.063)$ & $0.960(0.070)$ & $0.748(0.026)$ \\
\hline 11 May-17 May & 5,432 & $0.904(0.019)$ & $0.957(0.050)$ & $0.846(0.045)$ & $0.732(0.019)$ \\
\hline 18 May-24 May & 1,779 & $0.961(0.017)$ & $0.957(0.033)$ & $0.880(0.041)$ & $0.809(0.030)$ \\
\hline 25 May-31 May & 991 & $0.939(0.027)$ & $0.899(0.052)$ & $1.028(0.091)$ & $0.869(0.066)$ \\
\hline 01 Jun-07 Jun & 107 & $1.066(0.137)$ & $0.549(0.103)$ & $1.203(0.291)$ & $0.704(0.173)$ \\
\hline 08 Jun-14 Jun & 113 & $0.864(0.096)$ & $0.951(0.180)$ & $0.567(0.110)$ & $0.465(0.056)$ \\
\hline 15 Jun-21 Jun & 41 & $1.102(0.270)$ & $0.714(0.413)$ & $0.778(0.713)$ & $0.612(0.471)$ \\
\hline 22 Jun-28 Jun & 52 & $0.748(0.103)$ & $0.573(0.152)$ & $1.100(0.765)$ & $0.472(0.326)$ \\
\hline Weighted mean* & & $0.929(0.013)$ & $0.919(0.026)$ & $0.911(0.036)$ & $0.746(0.019)$ \\
\hline
\end{tabular}

* Weighted means of the independent estimates for weekly pooled groups (30 March - 14 June), with weights inversely proportional to respective estimated relative variances. 
Table 4. Estimated survival probabilities for Snake River wild yearling chinook salmon detected and released to or PIT tagged and released to the tailrace at Lower Granite Dam in 2003. Daily groups pooled weekly. Estimates based on the Single-Release Model. Standard errors in parentheses. Abbreviations: LGR-Lower Granite Dam; LGO-Little Goose Dam; LMO-Lower Monumental Dam; MCN-McNary Dam.

\begin{tabular}{|c|c|c|c|c|c|}
\hline Date at LGR & $\begin{array}{l}\text { Number } \\
\text { released }\end{array}$ & $\begin{array}{c}\text { LGR } \\
\text { to LGO }\end{array}$ & $\begin{array}{c}\text { LGO } \\
\text { to } \mathrm{LMO}\end{array}$ & $\begin{array}{c}\mathrm{LMO} \\
\text { to } \mathrm{MCN}\end{array}$ & $\begin{array}{c}\text { LGR } \\
\text { to } \mathrm{MCN}\end{array}$ \\
\hline 30 Mar-05 Apr & 226 & $0.889(0.081)$ & $0.773(0.116)$ & $0.949(0.148)$ & $0.653(0.075)$ \\
\hline 06 Apr-12 Apr & 1,530 & $0.974(0.048)$ & $0.827(0.104)$ & $0.794(0.096)$ & $0.639(0.035)$ \\
\hline 13 Apr-19 Apr & 6,125 & $0.890(0.017)$ & $0.923(0.049)$ & $0.860(0.046)$ & $0.706(0.019)$ \\
\hline 20 Apr-26 Apr & 9,381 & $0.934(0.018)$ & $0.932(0.057)$ & $0.821(0.050)$ & $0.715(0.016)$ \\
\hline 27 Apr-03 May & 4,587 & $0.980(0.041)$ & $0.903(0.092)$ & $0.691(0.068)$ & $0.611(0.023)$ \\
\hline 04 May-10 May & 7,001 & $0.886(0.027)$ & $0.917(0.058)$ & $0.832(0.050)$ & $0.675(0.020)$ \\
\hline 11 May-17 May & 3,652 & $0.929(0.019)$ & $0.993(0.067)$ & $0.778(0.056)$ & $0.718(0.026)$ \\
\hline 18 May-24 May & 5,031 & $0.949(0.008)$ & $0.943(0.020)$ & $0.907(0.032)$ & $0.813(0.025)$ \\
\hline 25 May-31 May & 9,302 & $0.950(0.008)$ & $0.911(0.020)$ & $0.954(0.030)$ & $0.825(0.021)$ \\
\hline 01 Jun-07 Jun & 3,607 & $0.903(0.013)$ & $0.919(0.034)$ & $0.892(0.048)$ & $0.740(0.033)$ \\
\hline 08 Jun-14 Jun & 349 & $0.954(0.055)$ & $0.864(0.092)$ & $0.925(0.134)$ & $0.762(0.090)$ \\
\hline 15 Jun-21 Jun & 194 & $1.058(0.129)$ & $0.540(0.113)$ & $0.466(0.110)$ & $0.266(0.048)$ \\
\hline 22 Jun-28 Jun & 214 & $0.746(0.058)$ & $0.496(0.090)$ & NA & NA \\
\hline Weighted mean* & & $0.937(0.007)$ & $0.925(0.008)$ & $0.887(0.020)$ & $0.729(0.020)$ \\
\hline
\end{tabular}

* Weighted means of the independent estimates for weekly pooled groups (30 March-14 June), with weights inversely proportional to respective estimated relative variances. 
Table 5. Estimated survival probabilities for Snake River yearling chinook salmon (hatchery and wild combined) detected and released to or PIT tagged and released to the tailrace at Lower Granite Dam in 2003. Daily groups pooled as necessary to calculate estimates. Estimates based on the Single-Release Model. Standard errors in parentheses. Abbreviations: LGR-Lower Granite Dam; LGO-Little Goose Dam; LMO-Lower Monumental Dam; MCN-McNary Dam.

\begin{tabular}{|c|c|c|c|c|c|}
\hline Date at LGR & $\begin{array}{l}\text { Number } \\
\text { released }\end{array}$ & $\begin{array}{c}\text { LGR } \\
\text { to } \mathrm{LGO} \\
\end{array}$ & $\begin{array}{c}\text { LGO } \\
\text { to } \mathrm{LMO} \\
\end{array}$ & $\begin{array}{c}\mathrm{LMO} \\
\text { to } \mathrm{MCN}\end{array}$ & $\begin{array}{c}\text { LGR } \\
\text { to } \mathrm{MCN} \\
\end{array}$ \\
\hline 23 Mar-30 Mar & 75 & $0.592(0.125)$ & $0.884(0.295)$ & $1.199(0.504)$ & $0.628(0.217)$ \\
\hline 31 Mar-01 Apr & 73 & $0.726(0.145)$ & $0.769(0.306)$ & $1.040(0.465)$ & $0.581(0.179)$ \\
\hline 02 Apr & 108 & $0.759(0.171)$ & $0.810(0.291)$ & $0.839(0.293)$ & $0.516(0.117)$ \\
\hline 03 Apr & 136 & $0.678(0.076)$ & $0.986(0.183)$ & $0.863(0.177)$ & $0.577(0.082)$ \\
\hline 04 Apr & 99 & $0.777(0.089)$ & $1.286(0.466)$ & $0.583(0.228)$ & $0.583(0.096)$ \\
\hline $05 \mathrm{Apr}$ & 71 & $1.661(0.979)$ & $0.393(0.283)$ & $0.732(0.331)$ & $0.478(0.124)$ \\
\hline 06 Apr & 71 & $0.848(0.125)$ & $1.272(0.624)$ & $0.917(0.510)$ & $0.988(0.266)$ \\
\hline $07 \mathrm{Apr}$ & 73 & $0.918(0.319)$ & $0.677(0.329)$ & $1.167(0.628)$ & $0.725(0.321)$ \\
\hline 08 Apr & 26 & $0.598(0.103)$ & $1.114(0.276)$ & $1.441(0.759)$ & $0.962(0.463)$ \\
\hline 09 Apr & 30 & $0.867(0.151)$ & $0.583(0.142)$ & $1.143(0.118)$ & $0.578(0.123)$ \\
\hline $10 \mathrm{Apr}$ & 473 & $0.996(0.092)$ & $0.669(0.131)$ & $0.902(0.149)$ & $0.602(0.054)$ \\
\hline $11 \mathrm{Apr}$ & 634 & $1.072(0.098)$ & $0.719(0.149)$ & $0.742(0.137)$ & $0.572(0.048)$ \\
\hline $12 \mathrm{Apr}$ & 452 & $0.892(0.080)$ & $0.872(0.208)$ & $1.076(0.263)$ & $0.838(0.107)$ \\
\hline 13 Apr & 207 & $0.870(0.090)$ & $0.952(0.231)$ & $0.874(0.222)$ & $0.723(0.094)$ \\
\hline 14 Apr & 218 & $0.798(0.077)$ & $0.912(0.218)$ & $0.761(0.187)$ & $0.554(0.065)$ \\
\hline $15 \mathrm{Apr}$ & 1,444 & $0.887(0.045)$ & $0.945(0.108)$ & $0.864(0.094)$ & $0.724(0.037)$ \\
\hline $16 \mathrm{Apr}$ & 1,738 & $0.913(0.038)$ & $0.897(0.089)$ & $0.845(0.084)$ & $0.692(0.034)$ \\
\hline 17 Apr & 1,343 & $0.882(0.034)$ & $0.969(0.114)$ & $0.789(0.096)$ & $0.674(0.039)$ \\
\hline $18 \mathrm{Apr}$ & 959 & $0.910(0.036)$ & $1.114(0.183)$ & $0.720(0.130)$ & $0.729(0.060)$ \\
\hline
\end{tabular}


Table 5. Continued.

\begin{tabular}{|c|c|c|c|c|c|}
\hline Date at LGR & $\begin{array}{l}\text { Number } \\
\text { released }\end{array}$ & $\begin{array}{c}\text { LGR } \\
\text { to LGO }\end{array}$ & $\begin{array}{c}\text { LGO } \\
\text { to LMO }\end{array}$ & $\begin{array}{c}\mathrm{LMO} \\
\text { to } \mathrm{MCN}\end{array}$ & $\begin{array}{c}\mathrm{LGR} \\
\text { to } \mathrm{MCN}\end{array}$ \\
\hline 19 Apr & 1,039 & $0.916(0.033)$ & $0.924(0.120)$ & $0.846(0.117)$ & $0.716(0.044)$ \\
\hline $20 \mathrm{Apr}$ & 219 & $1.056(0.113)$ & $0.571(0.105)$ & $1.245(0.224)$ & $0.752(0.098)$ \\
\hline $21 \mathrm{Apr}$ & 382 & $0.834(0.065)$ & $1.122(0.298)$ & $0.708(0.197)$ & $0.663(0.072)$ \\
\hline $22 \mathrm{Apr}$ & 2,026 & $0.958(0.035)$ & $0.809(0.084)$ & $0.965(0.102)$ & $0.748(0.038)$ \\
\hline $23 \mathrm{Apr}$ & 3,253 & $0.887(0.027)$ & $1.191(0.127)$ & $0.703(0.076)$ & $0.744(0.028)$ \\
\hline $24 \mathrm{Apr}$ & 2,744 & $0.970(0.036)$ & $0.829(0.089)$ & $0.914(0.098)$ & $0.736(0.032)$ \\
\hline $25 \mathrm{Apr}$ & 2,448 & $0.918(0.038)$ & $0.889(0.115)$ & $0.849(0.109)$ & $0.693(0.029)$ \\
\hline $26 \mathrm{Apr}$ & 2,193 & $0.934(0.037)$ & $0.817(0.099)$ & $0.879(0.107)$ & $0.670(0.032)$ \\
\hline $27 \mathrm{Apr}$ & 878 & $1.004(0.061)$ & $0.758(0.121)$ & $1.169(0.201)$ & $0.891(0.083)$ \\
\hline $28 \mathrm{Apr}$ & 559 & $1.002(0.110)$ & $0.566(0.103)$ & $1.072(0.176)$ & $0.608(0.058)$ \\
\hline $29 \mathrm{Apr}$ & 1,928 & $1.002(0.066)$ & $0.931(0.171)$ & $0.661(0.118)$ & $0.618(0.036)$ \\
\hline $30 \mathrm{Apr}$ & 1,373 & $1.018(0.076)$ & $0.723(0.104)$ & $1.012(0.151)$ & $0.745(0.068)$ \\
\hline 01 May & 920 & $0.931(0.075)$ & $0.897(0.154)$ & $0.709(0.124)$ & $0.592(0.052)$ \\
\hline 02 May & 1,295 & $0.928(0.066)$ & $1.054(0.196)$ & $0.622(0.114)$ & $0.608(0.042)$ \\
\hline 03 May & 1,476 & $0.885(0.064)$ & $0.823(0.155)$ & $0.957(0.184)$ & $0.697(0.061)$ \\
\hline 04 May & 519 & $0.855(0.105)$ & $0.673(0.142)$ & $1.355(0.308)$ & $0.780(0.120)$ \\
\hline 05 May & 1,229 & $0.847(0.059)$ & $0.840(0.110)$ & $1.306(0.188)$ & $0.929(0.087)$ \\
\hline 06 May & 2,574 & $0.959(0.056)$ & $0.879(0.094)$ & $0.791(0.079)$ & $0.667(0.030)$ \\
\hline 07 May & 2,663 & $0.912(0.051)$ & $0.841(0.091)$ & $0.868(0.087)$ & $0.665(0.031)$ \\
\hline 08 May & 2,949 & $0.859(0.037)$ & $0.871(0.081)$ & $1.030(0.095)$ & $0.772(0.037)$ \\
\hline 08 May & 2,949 & $0.859(0.037)$ & $0.871(0.081)$ & $1.030(0.095)$ & $0.772(0.037)$ \\
\hline 09 May & 1,778 & $1.012(0.072)$ & $0.867(0.143)$ & $0.736(0.115)$ & $0.645(0.036)$ \\
\hline 10 May & 940 & $0.868(0.061)$ & $1.072(0.180)$ & $0.660(0.113)$ & $0.615(0.053)$ \\
\hline
\end{tabular}


Table 5. Continued.

\begin{tabular}{|c|c|c|c|c|c|}
\hline Date at LGR & $\begin{array}{l}\text { Number } \\
\text { released }\end{array}$ & $\begin{array}{c}\text { LGR } \\
\text { to } \mathrm{LGO}\end{array}$ & $\begin{array}{c}\text { LGO } \\
\text { to } \mathrm{LMO}\end{array}$ & $\begin{array}{c}\mathrm{LMO} \\
\text { to } \mathrm{MCN} \\
\end{array}$ & $\begin{array}{c}\text { LGR } \\
\text { to } \mathrm{MCN} \\
\end{array}$ \\
\hline 11 May & 308 & $0.712(0.056)$ & $1.243(0.217)$ & $0.782(0.157)$ & $0.692(0.083)$ \\
\hline 12 May & 888 & $0.822(0.047)$ & $0.943(0.104)$ & $0.895(0.109)$ & $0.694(0.055)$ \\
\hline 13 May & 1,485 & $0.929(0.045)$ & $1.038(0.124)$ & $0.772(0.101)$ & $0.744(0.054)$ \\
\hline 14 May & 1,203 & $0.897(0.030)$ & $0.879(0.095)$ & $0.891(0.108)$ & $0.703(0.048)$ \\
\hline 15 May & 1,114 & $0.946(0.032)$ & $0.898(0.114)$ & $0.913(0.123)$ & $0.776(0.047)$ \\
\hline 16 May & 1,755 & $0.975(0.033)$ & $0.888(0.094)$ & $0.827(0.089)$ & $0.715(0.030)$ \\
\hline 17 May & 2,331 & $0.909(0.028)$ & $1.000(0.074)$ & $0.844(0.063)$ & $0.766(0.027)$ \\
\hline 18 May & 658 & $0.926(0.030)$ & $1.006(0.076)$ & $0.886(0.079)$ & $0.827(0.047)$ \\
\hline 19 May & 477 & $0.936(0.041)$ & $0.962(0.074)$ & $0.776(0.070)$ & $0.699(0.045)$ \\
\hline 20 May & 1,266 & $0.941(0.027)$ & $1.004(0.054)$ & $0.793(0.056)$ & $0.750(0.041)$ \\
\hline 21 May & 1,401 & $0.965(0.018)$ & $0.937(0.034)$ & $0.938(0.059)$ & $0.848(0.048)$ \\
\hline 22 May & 1,069 & $0.962(0.010)$ & $0.905(0.037)$ & $0.891(0.068)$ & $0.777(0.053)$ \\
\hline 23 May & 752 & $0.992(0.014)$ & $0.871(0.038)$ & $0.954(0.085)$ & $0.824(0.070)$ \\
\hline 24 May & 1,187 & $0.969(0.019)$ & $0.912(0.036)$ & $0.954(0.064)$ & $0.843(0.052)$ \\
\hline 25 May & 1,449 & $0.969(0.017)$ & $0.868(0.032)$ & $1.030(0.067)$ & $0.867(0.053)$ \\
\hline 26 May & 466 & $0.926(0.037)$ & $0.788(0.059)$ & $1.369(0.168)$ & $0.999(0.113)$ \\
\hline 27 May & 3,063 & $0.963(0.014)$ & $0.896(0.048)$ & $0.936(0.068)$ & $0.808(0.043)$ \\
\hline 28 May & 906 & $0.989(0.050)$ & $0.864(0.069)$ & $0.935(0.078)$ & $0.799(0.052)$ \\
\hline 29 May & 730 & $0.903(0.030)$ & $1.145(0.104)$ & $0.683(0.082)$ & $0.706(0.055)$ \\
\hline 30 May & 2,170 & $0.945(0.020)$ & $0.953(0.044)$ & $0.880(0.056)$ & $0.792(0.039)$ \\
\hline 31 May & 1,509 & $0.918(0.017)$ & $0.953(0.043)$ & $0.910(0.069)$ & $0.796(0.052)$ \\
\hline Weighted mean* & 69,802 & $0.946(0.005)$ & $0.916(0.011)$ & $0.904(0.017)$ & $0.731(0.010)$ \\
\hline
\end{tabular}

* Weighted means of the independent estimates for daily groups (29 March-31 May), with weights inversely proportional to respective estimated relative variances. 
Table 6. Estimated detection probabilities for Snake River yearling chinook salmon (hatchery and wild combined) detected and released to or PIT tagged and released to the tailrace at Lower Granite Dam in 2003. Daily groups pooled weekly. Estimates based on the Single-Release Model. Standard errors in parentheses. Abbreviations: LGR-Lower Granite Dam; LGO-Little Goose Dam; LMO-Lower Monumental Dam; MCN-McNary Dam.

\begin{tabular}{lcccc}
\hline & $\begin{array}{c}\text { Number } \\
\text { Date at LGR }\end{array}$ & LGO & LMO & MCN \\
\hline 30 Mar-05 Apr & 506 & $0.300(0.031)$ & $0.151(0.026)$ & $0.542(0.051)$ \\
06 Apr-12 Apr & 1,759 & $0.394(0.021)$ & $0.120(0.015)$ & $0.495(0.028)$ \\
13 Apr-19 Apr & 6,948 & $0.419(0.010)$ & $0.117(0.007)$ & $0.548(0.015)$ \\
20 Apr-26 Apr & 13,265 & $0.340(0.007)$ & $0.062(0.004)$ & $0.483(0.010)$ \\
27 Apr-03 May & 8,429 & $0.251(0.008)$ & $0.072(0.005)$ & $0.383(0.013)$ \\
04 May-10 May & 12,652 & $0.231(0.007)$ & $0.088(0.005)$ & $0.369(0.010)$ \\
11 May-17 May & 9,084 & $0.375(0.008)$ & $0.104(0.005)$ & $0.414(0.011)$ \\
18 May-24 May & 6,810 & $0.561(0.008)$ & $0.480(0.010)$ & $0.367(0.012)$ \\
25 May-31 May & 10,293 & $0.549(0.007)$ & $0.390(0.009)$ & $0.298(0.010)$ \\
01 Jun-07 Jun & 3,714 & $0.572(0.012)$ & $0.433(0.016)$ & $0.519(0.025)$ \\
08 Jun-14 Jun & 462 & $0.390(0.030)$ & $0.279(0.032)$ & $0.652(0.060)$ \\
15 Jun-21 Jun & 235 & $0.407(0.055)$ & $0.426(0.075)$ & $0.727(0.134)$ \\
22 Jun-28 Jun & 266 & $0.722(0.052)$ & $0.516(0.078)$ & $0.875(0.117)$ \\
\hline
\end{tabular}


Table 7. Estimated detection probabilities for Snake River yearling chinook salmon (hatchery and wild combined) detected and released to the tailrace at McNary Dam in 2003. Daily groups pooled weekly. Estimates based on the Single-Release Model. Standard errors in parentheses. Abbreviations: MCN-McNary Dam; JDA-John Day Dam; BON-Bonneville Dam.

\begin{tabular}{lccc}
\hline Date at MCN & $\begin{array}{l}\text { Number } \\
\text { released }\end{array}$ & JDA & BON \\
\hline 20 Apr-26 Apr & 1,463 & $0.184(0.022)$ & $0.249(0.072)$ \\
27 Apr-03 May & 9,538 & $0.182(0.009)$ & $0.178(0.027)$ \\
04 May-10 May & 16,748 & $0.166(0.008)$ & $0.193(0.020)$ \\
11 May-17 May & 19,814 & $0.202(0.007)$ & $0.192(0.018)$ \\
18 May-24 May & 15,423 & $0.263(0.009)$ & $0.198(0.024)$ \\
25 May-31 May & 6,172 & $0.442(0.016)$ & $0.183(0.036)$ \\
01 Jun-07 Jun & 2,188 & $0.305(0.018)$ & $0.358(0.067)$ \\
\hline
\end{tabular}


Table 8. Estimated detection probabilities for Snake River hatchery yearling chinook salmon detected and released to the tailrace at Lower Granite Dam in 2003. Daily groups pooled weekly. Estimates based on the Single-Release Model. Standard errors in parentheses. Abbreviations: LGR-Lower Granite Dam; LGO-Little Goose Dam; LMO-Lower Monumental Dam; MCN-McNary Dam.

\begin{tabular}{lcccc}
\hline & $\begin{array}{c}\text { Number } \\
\text { released }\end{array}$ & LGO & LMO & MCN \\
\hline Date at LGR & 280 & $0.258(0.044)$ & $0.078(0.028)$ & $0.585(0.077)$ \\
06 Apr-12 Apr & 229 & $0.322(0.047)$ & $0.123(0.034)$ & $0.392(0.068)$ \\
13 Apr-19 Apr & 823 & $0.308(0.024)$ & $0.077(0.015)$ & $0.465(0.040)$ \\
20 Apr-26 Apr & 3,884 & $0.264(0.011)$ & $0.054(0.006)$ & $0.405(0.017)$ \\
27 Apr-03 May & 3,842 & $0.229(0.011)$ & $0.064(0.007)$ & $0.304(0.017)$ \\
04 May-10 May & 5,650 & $0.163(0.008)$ & $0.053(0.005)$ & $0.321(0.013)$ \\
11 May-17 May & 5,432 & $0.294(0.009)$ & $0.083(0.006)$ & $0.398(0.013)$ \\
18 May-24 May & 1,779 & $0.465(0.014)$ & $0.341(0.015)$ & $0.375(0.019)$ \\
25 May-31 May & 991 & $0.463(0.021)$ & $0.311(0.022)$ & $0.228(0.023)$ \\
01 Jun-07 Jun & 107 & $0.403(0.070)$ & $0.577(0.078)$ & $0.475(0.129)$ \\
08 Jun-14 Jun & 113 & $0.359(0.061)$ & $0.322(0.070)$ & $0.935(0.063)$ \\
15 Jun-21 Jun & 41 & $0.442(0.133)$ & $0.250(0.148)$ & $0.333(0.272)$ \\
22 Jun-28 Jun & 52 & $0.720(0.108)$ & $0.500(0.144)$ & $0.500(0.354)$ \\
\hline
\end{tabular}


Table 9. Estimated detection probabilities for Snake River wild yearling chinook salmon detected and released to or PIT tagged and released to the tailrace at Lower Granite Dam in 2003. Daily groups pooled weekly. Estimates based on the Single-Release Model. Standard errors in parentheses. Abbreviations: LGR-Lower Granite Dam; LGO-Little Goose Dam; LMO-Lower Monumental Dam; MCN-McNary Dam.

\begin{tabular}{lcccc}
\hline & $\begin{array}{c}\text { Number } \\
\text { released }\end{array}$ & LGO & LMO & MCN \\
\hline 30 Mar-05 Apr & 226 & $0.338(0.045)$ & $0.218(0.042)$ & $0.511(0.068)$ \\
06 Apr-12 Apr & 1,530 & $0.399(0.023)$ & $0.116(0.016)$ & $0.514(0.030)$ \\
13 Apr-19 Apr & 6,125 & $0.437(0.010)$ & $0.126(0.008)$ & $0.562(0.016)$ \\
20 Apr-26 Apr & 9,381 & $0.375(0.009)$ & $0.067(0.005)$ & $0.521(0.013)$ \\
27 Apr-03 May & 4,587 & $0.271(0.013)$ & $0.077(0.008)$ & $0.463(0.019)$ \\
04 May-10 May & 7,001 & $0.292(0.011)$ & $0.121(0.008)$ & $0.417(0.014)$ \\
11 May-17 May & 3,652 & $0.495(0.013)$ & $0.147(0.012)$ & $0.449(0.019)$ \\
18 May-24 May & 5,031 & $0.600(0.009)$ & $0.560(0.013)$ & $0.362(0.015)$ \\
25 May-31 May & 9,302 & $0.559(0.007)$ & $0.402(0.010)$ & $0.310(0.011)$ \\
01 Jun-07 Jun & 3,607 & $0.579(0.012)$ & $0.427(0.017)$ & $0.520(0.026)$ \\
08 Jun-14 Jun & 349 & $0.400(0.035)$ & $0.266(0.035)$ & $0.562(0.072)$ \\
15 Jun-21 Jun & 194 & $0.399(0.060)$ & $0.467(0.083)$ & $0.875(0.117)$ \\
22 Jun-28 Jun & 214 & $0.721(0.060)$ & $0.519(0.093)$ & NA \\
\hline
\end{tabular}


Table 10. Estimated survival probabilities for juvenile Snake River steelhead (hatchery and wild combined) detected and released to or PIT tagged and released to the tailrace at Lower Granite Dam in 2003. Daily groups pooled weekly. Estimates based on the Single-Release Model. Standard errors in parentheses. Abbreviations: LGR-Lower Granite Dam; LGO-Little Goose Dam; LMO-Lower Monumental Dam; MCN-McNary Dam.

\begin{tabular}{|c|c|c|c|c|c|}
\hline Date at LGR & $\begin{array}{l}\text { Number } \\
\text { released }\end{array}$ & $\begin{array}{c}\text { LGR } \\
\text { to } \mathrm{LGO}\end{array}$ & $\begin{array}{c}\text { LGO } \\
\text { to LMO }\end{array}$ & $\begin{array}{c}\mathrm{LMO} \\
\text { to } \mathrm{MCN}\end{array}$ & $\begin{array}{c}\text { LGR } \\
\text { to } \mathrm{MCN}\end{array}$ \\
\hline 30 Mar-05 Apr & 87 & $0.831(0.130)$ & $0.980(0.451)$ & $0.651(0.387)$ & $0.530(0.216)$ \\
\hline 06 Apr-12 Apr & 2,206 & $0.982(0.039)$ & $0.896(0.081)$ & $0.783(0.107)$ & $0.688(0.077)$ \\
\hline 13 Apr-19 Apr & 4,206 & $0.890(0.026)$ & $0.839(0.057)$ & $1.000(0.106)$ & $0.747(0.066)$ \\
\hline 20 Apr-26 Apr & 4,107 & $0.906(0.030)$ & $0.933(0.063)$ & $0.739(0.076)$ & $0.624(0.054)$ \\
\hline 27 Apr-03 May & 5,681 & $0.885(0.026)$ & $0.968(0.055)$ & $0.719(0.069)$ & $0.616(0.051)$ \\
\hline 04 May-10 May & 7,111 & $0.870(0.024)$ & $0.904(0.043)$ & $0.668(0.048)$ & $0.525(0.032)$ \\
\hline 11 May-17 May & 9,468 & $0.948(0.019)$ & $0.973(0.038)$ & $0.637(0.032)$ & $0.587(0.023)$ \\
\hline 18 May-24 May & 13,899 & $0.941(0.006)$ & $0.908(0.017)$ & $0.713(0.034)$ & $0.609(0.027)$ \\
\hline 25 May-31 May & 9,270 & $0.996(0.010)$ & $0.850(0.025)$ & $0.757(0.044)$ & $0.641(0.033)$ \\
\hline 01 Jun-07 Jun & 4,016 & $0.951(0.012)$ & $0.808(0.032)$ & $0.513(0.059)$ & $0.395(0.043)$ \\
\hline Weighted mean* & & $0.947(0.005)$ & $0.898(0.012)$ & $0.708(0.018)$ & $0.597(0.013)$ \\
\hline
\end{tabular}

* Weighted means of the independent estimates for daily groups (05 April-31 May), with weights inversely proportional to respective estimated relative variances. 
Table 11. Estimated survival probabilities for juvenile Snake River steelhead (hatchery and wild combined) detected and released to the tailrace at McNary Dam in 2003. Daily groups pooled weekly. Estimates based on the Single-Release Model. Standard errors in parentheses. Abbreviations: MCN-McNary Dam; JDA-John Day Dam; BON-Bonneville Dam.

\begin{tabular}{|c|c|c|c|c|}
\hline Date at MCN & $\begin{array}{l}\text { Number } \\
\text { released }\end{array}$ & $\begin{array}{l}\mathrm{MCN} \\
\text { to JDA }\end{array}$ & $\begin{array}{c}\text { JDA } \\
\text { to BON }\end{array}$ & $\begin{array}{l}\mathrm{MCN} \\
\text { to } \mathrm{BON}\end{array}$ \\
\hline 27 Apr-03 May & 483 & $1.046(0.267)$ & $0.444(0.224)$ & $0.465(0.202)$ \\
\hline 04 May-10 May & 363 & $0.928(0.359)$ & NA & NA \\
\hline 11 May-17 May & 506 & $1.038(0.416)$ & $0.399(0.279)$ & $0.414(0.237)$ \\
\hline 18 May-24 May & 1,091 & $0.969(0.147)$ & $0.515(0.173)$ & $0.499(0.150)$ \\
\hline 15 May-31 May & 2,596 & $0.856(0.063)$ & $0.628(0.137)$ & $0.538(0.110)$ \\
\hline 01 Jun-07 Jun & 782 & $0.814(0.116)$ & $0.833(0.250)$ & $0.678(0.180)$ \\
\hline Weighted mean* & & $0.879(0.032)$ & $0.630(0.066)$ & $0.518(0.015)$ \\
\hline
\end{tabular}

* Weighted means of the independent estimates for weekly pooled groups (27 April-07 June), with weights inversely proportional to respective estimated relative variances. 
Table 12. Estimated survival probabilities for juvenile Snake River hatchery steelhead detected and released to or PIT tagged and released to the tailrace at Lower Granite Dam in 2003. Daily groups pooled weekly. Estimates based on the Single-Release Model. Standard errors in parentheses. Abbreviations: LGR-Lower Granite Dam; LGO-Little Goose Dam; LMO-Lower Monumental Dam; MCN-McNary Dam.

\begin{tabular}{|c|c|c|c|c|c|}
\hline Date at LGR & $\begin{array}{l}\text { Number } \\
\text { released }\end{array}$ & $\begin{array}{c}\text { LGR } \\
\text { to } \mathrm{LGO}\end{array}$ & $\begin{array}{c}\mathrm{LGO} \\
\text { to } \mathrm{LMO}\end{array}$ & $\begin{array}{c}\mathrm{LMO} \\
\text { to } \mathrm{MCN}\end{array}$ & $\begin{array}{c}\mathrm{LGR} \\
\text { to } \mathrm{MCN}\end{array}$ \\
\hline 06 Apr-12 Apr & 1,062 & $0.995(0.050)$ & $0.935(0.102)$ & $0.694(0.121)$ & $0.646(0.094)$ \\
\hline 13 Apr-19 Apr & 1,688 & $0.897(0.041)$ & $0.852(0.076)$ & $0.863(0.122)$ & $0.660(0.079)$ \\
\hline 20 Apr-26 Apr & 2,505 & $0.957(0.040)$ & $0.900(0.067)$ & $0.760(0.094)$ & $0.655(0.070)$ \\
\hline 27 Apr-03 May & 4,095 & $0.884(0.029)$ & $0.981(0.060)$ & $0.683(0.074)$ & $0.593(0.056)$ \\
\hline 04 May-10 May & 4,205 & $0.884(0.028)$ & $0.888(0.046)$ & $0.635(0.055)$ & $0.498(0.039)$ \\
\hline 11 May-17 May & 4,143 & $0.931(0.024)$ & $0.919(0.040)$ & $0.702(0.053)$ & $0.601(0.041)$ \\
\hline 18 May-24 May & 3,036 & $0.935(0.014)$ & $0.875(0.028)$ & $0.843(0.091)$ & $0.690(0.072)$ \\
\hline 25 May-31 May & 2,624 & $1.006(0.018)$ & $0.862(0.035)$ & $0.784(0.064)$ & $0.680(0.050)$ \\
\hline 01 Jun-07 Jun & 1,191 & $0.931(0.020)$ & $0.814(0.045)$ & $0.505(0.077)$ & $0.382(0.055)$ \\
\hline Weighted mean* & & $0.944(0.014)$ & $0.885(0.014)$ & $0.723(0.031)$ & $0.606(0.028)$ \\
\hline
\end{tabular}

* Weighted means of the independent estimates for weekly pooled groups (06 April-07 June), with weights inversely proportional to respective estimated relative variances. 
Table 13. Estimated survival probabilities for juvenile Snake River wild steelhead detected and released to or PIT tagged and released to the tailrace at Lower Granite Dam in 2003. Daily groups pooled weekly. Estimates based on the Single-Release Model. Standard errors in parentheses. Abbreviations: LGR-Lower Granite Dam; LGO-Little Goose Dam; LMO-Lower Monumental Dam; MCN-McNary Dam.

\begin{tabular}{|c|c|c|c|c|c|}
\hline Date at LGR & $\begin{array}{l}\text { Number } \\
\text { released }\end{array}$ & $\begin{array}{c}\text { LGR } \\
\text { to LGO }\end{array}$ & $\begin{array}{c}\mathrm{LGO} \\
\text { to } \mathrm{LMO}\end{array}$ & $\begin{array}{c}\mathrm{LMO} \\
\text { to } \mathrm{MCN}\end{array}$ & $\begin{array}{c}\text { LGR } \\
\text { to } \mathrm{MCN}\end{array}$ \\
\hline 06 Apr-12 Apr & 1,144 & $0.986(0.075)$ & $0.803(0.135)$ & $0.885(0.193)$ & $0.700(0.121)$ \\
\hline 13 Apr-19 Apr & 2,518 & $0.881(0.034)$ & $0.815(0.085)$ & $1.143(0.180)$ & $0.822(0.106)$ \\
\hline 20 Apr-26 Apr & 1,602 & $0.825(0.042)$ & $1.034(0.170)$ & $0.672(0.143)$ & $0.573(0.083)$ \\
\hline 27 Apr-03 May & 1,586 & $0.911(0.061)$ & $0.831(0.120)$ & $0.899(0.190)$ & $0.681(0.115)$ \\
\hline 04 May-10 May & 2,906 & $0.903(0.055)$ & $0.786(0.090)$ & $0.791(0.106)$ & $0.561(0.056)$ \\
\hline 11 May-17 May & 5,325 & $1.010(0.036)$ & $0.922(0.071)$ & $0.614(0.050)$ & $0.571(0.028)$ \\
\hline 18 May-24 May & 10,863 & $0.932(0.007)$ & $0.936(0.022)$ & $0.689(0.036)$ & $0.601(0.029)$ \\
\hline 25 May-31 May & 6,646 & $0.992(0.013)$ & $0.844(0.036)$ & $0.722(0.059)$ & $0.605(0.043)$ \\
\hline 01 Jun-07 Jun & 2,825 & $0.952(0.016)$ & $0.815(0.046)$ & $0.522(0.091)$ & $0.405(0.067)$ \\
\hline Weighted mean* & & $0.946(0.011)$ & $0.898(0.019)$ & $0.713(0.042)$ & $0.597(0.022)$ \\
\hline
\end{tabular}

* Weighted means of the independent estimates for weekly pooled groups (06 April-07 June), with weights inversely proportional to respective estimated relative variances. 
Table 14. Estimated survival probabilities for juvenile Snake River steelhead (hatchery and wild combined) detected and released to or PIT tagged and released to the tailrace at Lower Granite Dam in 2003. Daily groups pooled as necessary to calculate estimates. Estimates based on the Single-Release Model. Standard errors in parentheses. Abbreviations: LGR-Lower Granite Dam; LGO-Little Goose Dam; LMO-Lower Monumental Dam; MCN-McNary Dam.

\begin{tabular}{|c|c|c|c|c|c|}
\hline Date at LGR & $\begin{array}{l}\text { Number } \\
\text { released }\end{array}$ & $\begin{array}{c}\text { LGR } \\
\text { to } \mathrm{LGO}\end{array}$ & $\begin{array}{c}\mathrm{LGO} \\
\text { to } \mathrm{LMO}\end{array}$ & $\begin{array}{c}\mathrm{LMO} \\
\text { to } \mathrm{MCN}\end{array}$ & $\begin{array}{c}\mathrm{LGR} \\
\text { to } \mathrm{MCN}\end{array}$ \\
\hline 26 Mar-30 Mar & 13 & $1.231(0.298)$ & $0.714(0.517)$ & $0.800(0.716)$ & $0.703(0.453)$ \\
\hline 31 Mar-07 Apr & 105 & $0.903(0.177)$ & $0.867(0.331)$ & $0.633(0.302)$ & $0.496(0.175)$ \\
\hline 08 Apr-09 Apr & 200 & $1.048(0.112)$ & $1.024(0.221)$ & $0.710(0.283)$ & $0.763(0.267)$ \\
\hline $10 \mathrm{Apr}$ & 609 & $0.935(0.070)$ & $0.850(0.141)$ & $1.000(0.275)$ & $0.796(0.186)$ \\
\hline $11 \mathrm{Apr}$ & 690 & $1.123(0.095)$ & $0.753(0.139)$ & $0.625(0.149)$ & $0.528(0.095)$ \\
\hline $12 \mathrm{Apr}$ & 682 & $0.882(0.058)$ & $1.016(0.173)$ & $0.834(0.218)$ & $0.748(0.157)$ \\
\hline 13 Apr-14 Apr & 36 & $1.110(0.461)$ & $0.375(0.194)$ & $1.133(0.743)$ & $0.472(0.306)$ \\
\hline $15 \mathrm{Apr}$ & 321 & $0.862(0.088)$ & $0.864(0.202)$ & $1.100(0.513)$ & $0.819(0.345)$ \\
\hline 16 Apr & 672 & $1.000(0.082)$ & $0.880(0.150)$ & $1.062(0.302)$ & $0.936(0.227)$ \\
\hline 17 Apr & 733 & $0.808(0.058)$ & $0.908(0.141)$ & $0.844(0.198)$ & $0.620(0.118)$ \\
\hline $18 \mathrm{Apr}$ & 924 & $0.887(0.052)$ & $0.854(0.116)$ & $1.199(0.261)$ & $0.908(0.166)$ \\
\hline 19 Apr & 1,520 & $0.883(0.041)$ & $0.784(0.095)$ & $0.914(0.162)$ & $0.633(0.091)$ \\
\hline 20 Apr & 86 & $1.159(0.259)$ & $0.568(0.282)$ & $1.000(0.960)$ & $0.658(0.563)$ \\
\hline $21 \mathrm{Apr}$ & 134 & $0.802(0.119)$ & $1.016(0.345)$ & $0.639(0.316)$ & $0.522(0.202)$ \\
\hline $22 \mathrm{Apr}$ & 882 & $0.857(0.051)$ & $0.920(0.129)$ & $0.762(0.155)$ & $0.601(0.098)$ \\
\hline $23 \mathrm{Apr}$ & 891 & $0.907(0.068)$ & $0.905(0.144)$ & $0.975(0.264)$ & $0.801(0.187)$ \\
\hline $24 \mathrm{Apr}$ & 747 & $0.970(0.076)$ & $0.909(0.133)$ & $0.837(0.192)$ & $0.738(0.145)$ \\
\hline $25 \mathrm{Apr}$ & 726 & $0.914(0.087)$ & $1.238(0.260)$ & $0.407(0.116)$ & $0.460(0.099)$ \\
\hline
\end{tabular}


Table 14. Continued.

\begin{tabular}{|c|c|c|c|c|c|}
\hline Date at LGR & $\begin{array}{l}\text { Number } \\
\text { released }\end{array}$ & $\begin{array}{l}\text { LGR } \\
\text { to LGO }\end{array}$ & $\begin{array}{c}\text { LGO } \\
\text { to LMO }\end{array}$ & $\begin{array}{c}\mathrm{LMO} \\
\text { to } \mathrm{MCN}\end{array}$ & $\begin{array}{c}\text { LGR } \\
\text { to } \mathrm{MCN}\end{array}$ \\
\hline $26 \mathrm{Apr}$ & 641 & $0.883(0.068)$ & $0.848(0.120)$ & $0.776(0.179)$ & $0.582(0.116)$ \\
\hline 27 Apr & 237 & $0.923(0.112)$ & $1.052(0.276)$ & $1.227(0.689)$ & $1.191(0.608)$ \\
\hline $28 \mathrm{Apr}$ & 168 & $1.159(0.224)$ & $0.612(0.192)$ & $0.660(0.253)$ & $0.468(0.142)$ \\
\hline 29 Apr & 1,191 & $0.962(0.077)$ & $0.989(0.149)$ & $0.639(0.138)$ & $0.608(0.106)$ \\
\hline $30 \mathrm{Apr}$ & 1,049 & $0.835(0.057)$ & $1.090(0.151)$ & $0.605(0.144)$ & $0.551(0.113)$ \\
\hline 01 May & 994 & $0.875(0.057)$ & $0.910(0.114)$ & $1.203(0.359)$ & $0.958(0.267)$ \\
\hline 02 May & 1,079 & $0.859(0.055)$ & $0.956(0.118)$ & $0.689(0.139)$ & $0.566(0.098)$ \\
\hline 03 May & 963 & $0.868(0.057)$ & $0.944(0.116)$ & $0.693(0.149)$ & $0.567(0.107)$ \\
\hline 04 May - 05 May & 211 & $1.106(0.210)$ & $1.032(0.401)$ & $0.692(0.420)$ & $0.790(0.395)$ \\
\hline 06 May & 1,100 & $0.784(0.055)$ & $1.000(0.131)$ & $0.701(0.159)$ & $0.550(0.110)$ \\
\hline 07 May & 1,059 & $0.928(0.070)$ & $0.833(0.098)$ & $0.813(0.157)$ & $0.629(0.109)$ \\
\hline 08 May & 1,690 & $0.841(0.055)$ & $0.896(0.097)$ & $0.660(0.097)$ & $0.498(0.061)$ \\
\hline 09 May & 1,150 & $0.900(0.055)$ & $0.900(0.099)$ & $0.538(0.086)$ & $0.436(0.057)$ \\
\hline 10 May & 1,901 & $0.866(0.042)$ & $0.919(0.081)$ & $0.694(0.090)$ & $0.552(0.060)$ \\
\hline 11 May & 153 & $0.878(0.107)$ & $1.098(0.254)$ & $0.536(0.193)$ & $0.517(0.154)$ \\
\hline 12 May & 100 & $0.892(0.130)$ & $1.881(0.821)$ & $0.323(0.166)$ & $0.543(0.155)$ \\
\hline 13 May & 1,727 & $0.991(0.050)$ & $0.999(0.104)$ & $0.643(0.096)$ & $0.636(0.076)$ \\
\hline 14 May & 1,478 & $0.928(0.050)$ & $0.823(0.081)$ & $0.679(0.090)$ & $0.519(0.056)$ \\
\hline 15 May & 1,890 & $0.975(0.042)$ & $0.909(0.082)$ & $0.725(0.086)$ & $0.642(0.060)$ \\
\hline 16 May & 1,814 & $0.870(0.035)$ & $1.143(0.093)$ & $0.569(0.061)$ & $0.566(0.046)$ \\
\hline 17 May & 2,306 & $0.983(0.043)$ & $0.944(0.071)$ & $0.628(0.058)$ & $0.582(0.042)$ \\
\hline 18 May & 425 & $0.921(0.055)$ & $0.921(0.088)$ & $0.758(0.124)$ & $0.643(0.095)$ \\
\hline
\end{tabular}


Table 14. Continued.

\begin{tabular}{|c|c|c|c|c|c|}
\hline$\underline{\text { Date at LGR }}$ & $\begin{array}{l}\text { Number } \\
\text { released }\end{array}$ & $\begin{array}{c}\text { LGR } \\
\text { to } \mathrm{LGO}\end{array}$ & $\begin{array}{c}\text { LGO } \\
\text { to } \mathrm{LMO}\end{array}$ & $\begin{array}{c}\mathrm{LMO} \\
\text { to } \mathrm{MCN}\end{array}$ & $\begin{array}{c}\text { LGR } \\
\text { to } \mathrm{MCN}\end{array}$ \\
\hline 19 May & 207 & $0.891(0.066)$ & $0.927(0.118)$ & $0.707(0.197)$ & $0.583(0.152)$ \\
\hline 20 May & 2,990 & $0.940(0.021)$ & $0.863(0.037)$ & $0.724(0.062)$ & $0.588(0.046)$ \\
\hline 21 May & 2,349 & $0.946(0.015)$ & $0.908(0.039)$ & $0.792(0.090)$ & $0.681(0.072)$ \\
\hline 22 May & 2,947 & 0.937 (0.009) & $0.960(0.043)$ & $0.613(0.070)$ & $0.552(0.058)$ \\
\hline 23 May & 2,845 & $0.953(0.010)$ & $0.908(0.039)$ & $0.701(0.088)$ & $0.607(0.071)$ \\
\hline 24 May & 2,136 & $0.951(0.016)$ & $0.894(0.046)$ & $0.660(0.095)$ & $0.561(0.075)$ \\
\hline 25 May & 1,067 & $0.985(0.028)$ & $0.953(0.083)$ & $0.421(0.092)$ & $0.395(0.079)$ \\
\hline 26 May & 426 & $1.032(0.042)$ & $0.808(0.086)$ & $0.666(0.174)$ & $0.555(0.135)$ \\
\hline 27 May & 2,573 & $0.942(0.015)$ & $0.863(0.063)$ & $0.789(0.108)$ & $0.642(0.076)$ \\
\hline 28 May & 1423 & $0.996(0.040)$ & $0.868(0.068)$ & $0.833(0.116)$ & $0.720(0.088)$ \\
\hline 29 May & 1448 & $1.094(0.040)$ & $0.691(0.049)$ & $0.791(0.087)$ & $0.598(0.059)$ \\
\hline 30 May & 1111 & $0.968(0.023)$ & $0.951(0.082)$ & $0.736(0.109)$ & $0.677(0.083)$ \\
\hline 31 May & 1222 & $0.964(0.022)$ & $0.905(0.057)$ & $0.687(0.103)$ & $0.599(0.082)$ \\
\hline 01 Jun-02 Jun & 589 & $0.958(0.017)$ & $0.973(0.103)$ & $0.432(0.110)$ & $0.402(0.091)$ \\
\hline 03 Jun & 709 & $0.957(0.024)$ & $0.912(0.090)$ & $0.730(0.209)$ & $0.637(0.172)$ \\
\hline 04 Jun & 736 & $0.999(0.031)$ & $0.749(0.071)$ & $0.395(0.108)$ & $0.295(0.076)$ \\
\hline 05 Jun & 640 & $0.897(0.031)$ & $0.831(0.069)$ & $0.726(0.246)$ & $0.541(0.179)$ \\
\hline 06 Jun & 723 & $0.972(0.041)$ & $0.713(0.064)$ & $0.389(0.082)$ & $0.270(0.054)$ \\
\hline 07 Jun & 619 & $0.942(0.037)$ & $0.673(0.074)$ & $0.582(0.247)$ & $0.369(0.152)$ \\
\hline Weighted mean* & 60057 & $0.947(0.005)$ & $0.898(0.012)$ & $0.708(0.018)$ & $0.597(0.013)$ \\
\hline
\end{tabular}

* Weighted means of the independent estimates for daily groups (05 April - 31 May), with weights inversely proportional to respective estimated relative variances. 
Table 15. Estimated detection probabilities for juvenile Snake River steelhead (hatchery and wild combined) detected and released to or PIT tagged and released to the tailrace at Lower Granite Dam in 2003. Daily groups pooled weekly. Estimates based on the Single-Release Model. Standard errors in parentheses. Abbreviations: LGR-Lower Granite Dam; LGO-Little Goose Dam; LMO-Lower Monumental Dam; MCN-McNary Dam.

\begin{tabular}{lcccc}
\hline & $\begin{array}{c}\text { Number } \\
\text { released }\end{array}$ & LGO & LMO & MCN \\
\hline 30 Mar-05 Apr & 87 & $0.484(0.093)$ & $0.156(0.081)$ & $0.366(0.162)$ \\
06 Apr-12 Apr & 2,206 & $0.382(0.018)$ & $0.225(0.020)$ & $0.141(0.019)$ \\
13 Apr-19 Apr & 4,206 & $0.416(0.014)$ & $0.212(0.015)$ & $0.133(0.013)$ \\
20 Apr-26 Apr & 4,107 & $0.328(0.013)$ & $0.216(0.014)$ & $0.141(0.014)$ \\
27 Apr-03 May & 5,681 & $0.283(0.010)$ & $0.238(0.013)$ & $0.127(0.012)$ \\
04 May-10 May & 7,111 & $0.273(0.009)$ & $0.286(0.012)$ & $0.179(0.013)$ \\
11 May-17 May & 9,468 & $0.320(0.008)$ & $0.264(0.010)$ & $0.236(0.011)$ \\
18 May-24 May & 13,899 & $0.627(0.006)$ & $0.558(0.011)$ & $0.194(0.010)$ \\
25 May-31 May & 9,270 & $0.579(0.008)$ & $0.396(0.012)$ & $0.157(0.010)$ \\
01 Jun-07 Jun & 4,016 & $0.648(0.011)$ & $0.646(0.024)$ & $0.324(0.038)$ \\
\hline
\end{tabular}


Table 16. Estimated detection probabilities for juvenile Snake River steelhead (hatchery and wild combined) detected and released to the tailrace at McNary Dam in 2003. Daily groups pooled weekly. Estimates based on the Single-Release Model. Standard errors in parentheses. Abbreviations: MCN-McNary Dam; JDA-John Day Dam; BON-Bonneville Dam.

\begin{tabular}{lccc}
\hline Date at MCN & $\begin{array}{c}\text { Number } \\
\text { released }\end{array}$ & JDA & BON \\
\hline 27 Apr-03 May & 483 & $0.119(0.034)$ & $0.397(0.175)$ \\
04 May-10 May & 363 & $0.086(0.037)$ & NA \\
11 May-17 May & 506 & $0.074(0.032)$ & $0.306(0.178)$ \\
18 May-24 May & 1,091 & $0.153(0.026)$ & $0.302(0.063)$ \\
15 May-31 May & 2,596 & $0.245(0.020)$ & $0.401(0.108)$ \\
01 Jun-07 Jun & 782 & $0.127(0.022)$ & \\
\hline
\end{tabular}


Table 17. Estimated detection probabilities for juvenile Snake River hatchery steelhead detected and released to or PIT tagged and released to the tailrace at Lower Granite Dam in 2003. Daily groups pooled weekly. Estimates based on the Single-Release Model. Standard errors in parentheses. Abbreviations: LGR-Lower Granite Dam; LGO-Little Goose Dam; LMO-Lower Monumental Dam; MCN-McNary Dam.

\begin{tabular}{lcccc}
\hline & $\begin{array}{l}\text { Number } \\
\text { released }\end{array}$ & LGO & LMO & MCN \\
\hline 06 Apr-12 Apr & 1,062 & $0.349(0.023)$ & $0.218(0.025)$ & $0.122(0.022)$ \\
13 Apr-19 Apr & 1,688 & $0.324(0.019)$ & $0.208(0.019)$ & $0.119(0.017)$ \\
20 Apr-26 Apr & 2,505 & $0.256(0.014)$ & $0.242(0.018)$ & $0.127(0.016)$ \\
27 Apr-03 May & 4,095 & $0.260(0.011)$ & $0.259(0.015)$ & $0.124(0.013)$ \\
04 May-10 May & 4,205 & $0.244(0.010)$ & $0.337(0.016)$ & $0.163(0.015)$ \\
11 May-17 May & 4,143 & $0.282(0.010)$ & $0.360(0.015)$ & $0.169(0.014)$ \\
18 May-24 May & 3,036 & $0.542(0.012)$ & $0.537(0.018)$ & $0.101(0.012)$ \\
25 May-31 May & 2,624 & $0.530(0.013)$ & $0.381(0.017)$ & $0.174(0.015)$ \\
01 Jun-07 Jun & 1,191 & $0.631(0.019)$ & $0.622(0.034)$ & $0.318(0.050)$ \\
\hline
\end{tabular}


Table 18. Estimated detection probabilities for juvenile Snake River wild steelhead detected and released to or PIT tagged and released to the tailrace at Lower Granite Dam in 2003. Daily groups pooled weekly. Estimates based on the Single-Release Model. Standard errors in parentheses. Abbreviations: LGR-Lower Granite Dam; LGO-Little Goose Dam; LMO-Lower Monumental Dam; MCN-McNary Dam.

\begin{tabular}{lcccc}
\hline & $\begin{array}{l}\text { Number } \\
\text { released }\end{array}$ & LGO & LMO & MCN \\
\hline 06 Apr-12 Apr & 1,144 & $0.407(0.034)$ & $0.240(0.035)$ & $0.178(0.034)$ \\
13 Apr-19 Apr & 2,518 & $0.481(0.021)$ & $0.220(0.022)$ & $0.149(0.021)$ \\
20 Apr-26 Apr & 1,602 & $0.458(0.026)$ & $0.155(0.026)$ & $0.179(0.030)$ \\
27 Apr-03 May & 1,586 & $0.333(0.025)$ & $0.185(0.025)$ & $0.139(0.026)$ \\
04 May-10 May & 2,906 & $0.298(0.020)$ & $0.213(0.021)$ & $0.213(0.024)$ \\
11 May-17 May & 5,325 & $0.332(0.014)$ & $0.187(0.013)$ & $0.307(0.017)$ \\
18 May-24 May & 10,863 & $0.658(0.006)$ & $0.574(0.013)$ & $0.255(0.014)$ \\
25 May-31 May & 6,646 & $0.598(0.010)$ & $0.405(0.017)$ & $0.144(0.013)$ \\
01 Jun-07 Jun & 2,825 & $0.659(0.014)$ & $0.665(0.033)$ & $0.332(0.058)$ \\
\hline
\end{tabular}


Table 19. Estimated survival probabilities for PIT-tagged yearling chinook salmon released from Snake River Basin hatcheries in 2003. Estimates based on the Single-Release Model. Standard errors in parentheses. Abbreviations: Rel-Release site; LGR-Lower Granite Dam; LGO-Little Goose Dam; LMO-Lower Monumental Dam; MCN-McNary Dam.

\begin{tabular}{|c|c|c|c|c|c|c|}
\hline Release site & $\begin{array}{l}\text { Number } \\
\text { released }\end{array}$ & $\begin{array}{c}\text { Rel } \\
\text { to LGR }\end{array}$ & $\begin{array}{c}\text { LGR } \\
\text { to } \mathrm{LGO}\end{array}$ & $\begin{array}{c}\text { LGO } \\
\text { to LMO }\end{array}$ & $\begin{array}{c}\mathrm{LMO} \\
\text { to } \mathrm{MCN}\end{array}$ & $\begin{array}{c}\text { Rel } \\
\text { to } \mathrm{MCN}\end{array}$ \\
\hline \multicolumn{7}{|c|}{ Clearwater Hatchery } \\
\hline Crooked River & 299 & $0.270(0.040)$ & $1.038(0.245)$ & $0.930(0.435)$ & $1.326(0.833)$ & $0.346(0.167)$ \\
\hline Powell Pond & 295 & $0.854(0.141)$ & $0.657(0.162)$ & $0.462(0.098)$ & $1.647(0.252)$ & $0.427(0.081)$ \\
\hline Red River Pond & 297 & $0.591(0.065)$ & $1.117(0.220)$ & $1.074(0.409)$ & $0.657(0.262)$ & $0.465(0.096)$ \\
\hline Papoose Creek & 799 & $0.244(0.027)$ & $0.860(0.130)$ & NA & NA & NA \\
\hline Lolo Creek & 1,026 & $0.366(0.030)$ & $0.799(0.087)$ & $1.451(0.368)$ & $0.769(0.219)$ & $0.326(0.050)$ \\
\hline Meadow Creek & 1,053 & $0.577(0.031)$ & $0.986(0.082)$ & $0.814(0.120)$ & $0.977(0.150)$ & $0.452(0.040)$ \\
\hline Newsome Creek & 1,051 & $0.521(0.036)$ & $0.788(0.074)$ & $1.229(0.270)$ & $0.700(0.168)$ & $0.353(0.042)$ \\
\hline \multicolumn{7}{|c|}{ Dworshak Hatchery } \\
\hline Dworshak H. & 51,476 & $0.720(0.008)$ & $0.916(0.016)$ & $0.903(0.024)$ & $0.975(0.027)$ & $0.581(0.009)$ \\
\hline \multicolumn{7}{|c|}{ Kooskia Hatchery } \\
\hline Kooskia H. & 750 & $0.560(0.043)$ & $0.818(0.088)$ & $0.867(0.138)$ & $0.738(0.116)$ & $0.293(0.026)$ \\
\hline Clear Creek & 751 & $0.759(0.051)$ & $0.834(0.085)$ & $0.945(0.158)$ & $0.878(0.156)$ & $0.525(0.053)$ \\
\hline \multicolumn{7}{|c|}{ McCall Hatchery } \\
\hline Johnson Creek & 12,132 & $0.244(0.009)$ & $0.967(0.063)$ & $0.853(0.094)$ & $1.016(0.120)$ & $0.205(0.015)$ \\
\hline$\underline{\text { Knox Bridge }}$ & 51,521 & $0.573(0.006)$ & $0.932(0.018)$ & $0.883(0.030)$ & $1.036(0.036)$ & $0.488(0.009)$ \\
\hline
\end{tabular}


Table 19. Continued.

\begin{tabular}{|c|c|c|c|c|c|c|}
\hline Release site & $\begin{array}{l}\text { Number } \\
\text { released }\end{array}$ & $\begin{array}{l}\text { Rel } \\
\text { to LGR }\end{array}$ & $\begin{array}{c}\text { LGR } \\
\text { to LGO }\end{array}$ & $\begin{array}{c}\text { LGO } \\
\text { to LMO }\end{array}$ & $\begin{array}{c}\mathrm{LMO} \\
\text { to } \mathrm{MCN}\end{array}$ & $\begin{array}{c}\text { Rel } \\
\text { to } \mathrm{MCN}\end{array}$ \\
\hline \multicolumn{7}{|c|}{ Lookingglass Hatchery } \\
\hline Catherine Creek Pond $(3 / 23)$ & 13,707 & $0.370(0.011)$ & $0.959(0.058)$ & $0.812(0.079)$ & $1.117(0.111)$ & $0.322(0.018)$ \\
\hline Catherine Creek Pond (4/14) & 6,921 & $0.314(0.011)$ & $1.016(0.063)$ & $0.909(0.103)$ & $1.044(0.132)$ & $0.303(0.024)$ \\
\hline Grande Ronde R. Pond (3/23) & 990 & $0.369(0.026)$ & $0.945(0.092)$ & $0.762(0.120)$ & $1.215(0.219)$ & $0.323(0.43)$ \\
\hline Grande Ronde R. Pond (4/14) & 1,490 & $0.468(0.022)$ & $1.102(0.083)$ & $0.735(0.090)$ & $0.943(0.124)$ & $0.358(0.032)$ \\
\hline Imnaha Weir & 20,904 & $0.715(0.012)$ & $0.898(0.027)$ & $0.918(0.054)$ & $0.900(0.055)$ & $0.531(0.015)$ \\
\hline Lostine River Pond (3/17) & 2,667 & $0.540(0.020)$ & $0.882(0.055)$ & $0.903(0.110)$ & $0.908(0.117)$ & $0.391(0.027)$ \\
\hline Lostine River Pond (4/01) & 5,291 & $0.601(0.020)$ & $0.898(0.050)$ & $0.788(0.072)$ & $0.976(0.095)$ & $0.415(0.025)$ \\
\hline \multicolumn{7}{|c|}{ Pahsimeroi Hatchery } \\
\hline Pahsimeroi Trap & 982 & $0.721(0.230)$ & NA & NA & NA & NA \\
\hline \multicolumn{7}{|c|}{ Rapid River Hatchery } \\
\hline Rapid River H. & 51,762 & $0.691(0.007)$ & $0.919(0.018)$ & $0.867(0.036)$ & $0.969(0.041)$ & $0.534(0.010)$ \\
\hline \multicolumn{7}{|c|}{ Sawtooth Hatchery } \\
\hline Sawtooth Trap & 989 & $0.595(0.149)$ & $0.641(0.238)$ & $0.875(0.117)$ & NA & NA \\
\hline
\end{tabular}


Table 20. Estimated survival probabilities for PIT-tagged juvenile steelhead released from Snake River Basin hatcheries in 2003. Estimates based on the Single-Release Model. Standard errors in parentheses. Abbreviations: Rel-Release site; LGR-Lower Granite Dam; LGO-Little Goose Dam; LMO-Lower Monumental Dam; MCN-McNary Dam.

\begin{tabular}{|c|c|c|c|c|c|c|}
\hline Release site & $\begin{array}{l}\text { Number } \\
\text { released }\end{array}$ & $\begin{array}{c}\text { Rel } \\
\text { to LGR }\end{array}$ & $\begin{array}{c}\text { LGR } \\
\text { to } \mathrm{LGO}\end{array}$ & $\begin{array}{c}\text { LGO } \\
\text { to } \mathrm{LMO}\end{array}$ & $\begin{array}{c}\mathrm{LMO} \\
\text { to } \mathrm{MCN}\end{array}$ & $\begin{array}{c}\text { Rel } \\
\text { to } \mathrm{MCN}\end{array}$ \\
\hline \multicolumn{7}{|c|}{ Clearwater Hatchery } \\
\hline S.F. Clearwater R. & 883 & $0.792(0.158)$ & $0.812(0.303)$ & NA & NA & $0.506(0.183)$ \\
\hline Crooked River Pond & 648 & $0.502(0.038)$ & $1.058(0.123)$ & $0.868(0.162)$ & $0.650(0.224)$ & $0.300(0.093)$ \\
\hline Red River Pond & 535 & $0.853(0.364)$ & $0.744(0.515)$ & $1.066(0.951)$ & $0.443(0.425)$ & $0.300(0.135)$ \\
\hline Crooked River & 841 & $0.434(0.050)$ & $0.989(0.212)$ & $1.098(0.594)$ & $0.760(0.693)$ & $0.359(0.198)$ \\
\hline Lolo Creek & 535 & $0.821(0.283)$ & $0.566(0.277)$ & NA & NA & NA \\
\hline Meadow Creek & 525 & $0.310(0.047)$ & $1.145(0.301)$ & $0.416(0.145)$ & $0.431(0.249)$ & $0.604(0.034)$ \\
\hline \multicolumn{7}{|c|}{ Dworshak Hatchery } \\
\hline Dworshak H. & 1,500 & $0.795(0.032)$ & $0.942(0.061)$ & $0.904(0.095)$ & $0.537(0.100)$ & $0.363(0.060)$ \\
\hline
\end{tabular}


Table 21. Estimated survival probabilities for PIT-tagged juvenile sockeye salmon from Sawtooth and Bonneville hatcheries and coho salmon from Kooskia and Clearwater hatcheries released in 2003. Estimates based on the Single-Release Model. Standard errors in parentheses. Abbreviations: Rel-Release site; LGR-Lower Granite Dam; LGO-Little Goose Dam; LMO-Lower Monumental Dam; MCN-McNary Dam.

\begin{tabular}{|c|c|c|c|c|c|c|c|c|}
\hline Release site & $\begin{array}{c}\text { Release } \\
\text { date }\end{array}$ & $\begin{array}{l}\text { Number } \\
\text { released }\end{array}$ & $\begin{array}{c}\text { Rel } \\
\text { to LGR }\end{array}$ & $\begin{array}{c}\text { LGR } \\
\text { to } \mathrm{LGO}\end{array}$ & $\begin{array}{c}\mathrm{LGO} \\
\text { to } \mathrm{LMO}\end{array}$ & $\begin{array}{c}\mathrm{LMO} \\
\text { to } \mathrm{MCN}\end{array}$ & $\begin{array}{c}\mathrm{LGR} \\
\text { to } \mathrm{MCN}\end{array}$ & $\begin{array}{c}\text { Rel } \\
\text { to } \mathrm{MCN}\end{array}$ \\
\hline \multicolumn{9}{|c|}{ Sawtooth Hatchery sockeye salmon } \\
\hline Pettit Lake & 08 Oct 02 & 2,013 & $0.444(0.021)$ & $0.869(0.050)$ & $1.034(0.115)$ & $0.772(0.135)$ & $0.636(0.139)^{*}$ & $0.308(0.044)$ \\
\hline Redfish Lake & 08 Oct 02 & 1,015 & $0.116(0.016)$ & $0.785(0.110)$ & $0.824(0.130)$ & $0.900(0.309)$ & & $0.068(0.023)$ \\
\hline \multicolumn{9}{|c|}{ Bonneville Hatchery sockeye salmon } \\
\hline Alturus Lake & 27 Aug 02 & 1,481 & $0.034(0.017)$ & $0.680(0.355)$ & $1.175(0.674)$ & $0.300(0.190)$ & & $0.008(0.003)$ \\
\hline Pettit Lake & 27 Aug 02 & 1,565 & $0.345(0.024)$ & $0.874(0.078)$ & $0.930(0.140)$ & $0.683(0.192)$ & & $0.191(0.047)$ \\
\hline Redfish Lake & 29 Aug 02 & 1,007 & $0.068(0.015)$ & $0.760(0.177)$ & $1.020(0.288)$ & $0.440(0.184)$ & & $0.023(0.008)$ \\
\hline \multicolumn{9}{|c|}{ Kooskia Hatchery coho salmon } \\
\hline Kooskia Hatchery & 10 Apr 03 & 1,000 & $0.650(0.033)$ & $0.990(0.067)$ & $1.022(0.127)$ & $0.777(0.148)$ & $0.604(0.151)^{\mathrm{b}}$ & $0.512(0.079)$ \\
\hline \multicolumn{9}{|c|}{ Clearwater Hatchery coho salmon } \\
\hline S.F. Clearwater R. & $08 \mathrm{Jul} 02$ & 1,990 & $0.050(0.014)$ & $0.433(0.178)$ & $0.588(0.234)$ & NA & & $0.022(0.019)$ \\
\hline Eldorado Creek & $08 \mathrm{Jul} 02$ & 1,006 & $0.039(0.007)$ & $0.942(0.241)$ & $0.625(0.345)$ & $0.356(0.295)$ & & $0.008(0.006)$ \\
\hline Meadow Creek & $08 \mathrm{Jul} 02$ & 996 & $0.028(0.007)$ & NA & NA & NA & & $0.004(0.002)$ \\
\hline
\end{tabular}

a. based on all sockeye salmon data pooled.

b. based on all coho salmon data pooled 
Table 22. Estimated detection probabilities for PIT-tagged yearling chinook salmon released from Snake River Basin hatcheries in 2003. Estimates based on the Single-Release Model. Standard errors in parentheses. Abbreviations: LGR-Lower Granite Dam; LGO-Little Goose Dam; LMO-Lower Monumental Dam; MCN-McNary Dam.

\begin{tabular}{|c|c|c|c|c|c|}
\hline Release site & Number released & LGR & LGO & LMO & $\mathrm{MCN}$ \\
\hline \multicolumn{6}{|c|}{ Clearwater Hatchery } \\
\hline Crooked River & 299 & $0.371(0.069)$ & $0.285(0.077)$ & $0.097(0.053)$ & $0.167(0.088)$ \\
\hline Powell Pond & 295 & $0.238(0.047)$ & $0.320(0.064)$ & $0.102(0.039)$ & $0.394(0.085)$ \\
\hline Red River Pond & 297 & $0.279(0.044)$ & $0.236(0.050)$ & $0.098(0.040)$ & $0.348(0.081)$ \\
\hline Papoose Creek & 799 & $0.334(0.045)$ & $0.294(0.049)$ & $0.029(0.020)$ & $0.168(0.068)$ \\
\hline Lolo Creek & 1,026 & $0.301(0.032)$ & $0.272(0.034)$ & $0.063(0.019)$ & $0.318(0.053)$ \\
\hline Meadow Creek & 1,053 & $0.301(0.024)$ & $0.267(0.026)$ & $0.088(0.017)$ & $0.448(0.043)$ \\
\hline Newsome Creek & 1,051 & $0.299(0.027)$ & $0.326(0.031)$ & $0.069(0.018)$ & $0.373(0.048)$ \\
\hline \multicolumn{6}{|c|}{ Dworshak Hatchery } \\
\hline Dworshak H. & 51,476 & $0.279(0.004)$ & $0.276(0.004)$ & $0.117(0.003)$ & $0.365(0.006)$ \\
\hline \multicolumn{6}{|c|}{ Kooskia Hatchery } \\
\hline Kooskia H. & 750 & $0.291(0.030)$ & $0.288(0.033)$ & $0.122(0.025)$ & $0.650(0.054)$ \\
\hline Clear Creek & 751 & $0.272(0.026)$ & $0.249(0.028)$ & $0.090(0.019)$ & $0.417(0.047)$ \\
\hline \multicolumn{6}{|l|}{ McCall Hatchery } \\
\hline Johnson Creek & 12,132 & $0.368(0.015)$ & $0.384(0.021)$ & $0.187(0.020)$ & $0.324(0.025)$ \\
\hline Knox Bridge & 51,521 & $0.321(0.004)$ & $0.264(0.005)$ & $0.091(0.003)$ & $0.318(0.006)$ \\
\hline
\end{tabular}


Table 22. Continued.

\begin{tabular}{|c|c|c|c|c|c|}
\hline Release site & $\begin{array}{l}\text { Number } \\
\text { released }\end{array}$ & LGR & LGO & LMO & $\mathrm{MCN}$ \\
\hline \multicolumn{6}{|c|}{ Lookingglass Hatchery } \\
\hline Catherine Creek Pond $(3 / 23)$ & 13,707 & $0.326(0.011)$ & $0.215(0.012)$ & $0.092(0.009)$ & $0.289(0.018)$ \\
\hline Catherine Creek Pond (4/14) & 6,921 & $0.356(0.015)$ & $0.300(0.018)$ & $0.122(0.015)$ & $0.254(0.022)$ \\
\hline Grande Ronde R. Pond (3/23) & 990 & $0.350(0.032)$ & $0.309(0.035)$ & $0.109(0.024)$ & $0.327(0.049)$ \\
\hline Grande Ronde R. Pond (4/14) & 1,490 & $0.350(0.022)$ & $0.281(0.025)$ & $0.132(0.020)$ & $0.358(0.036)$ \\
\hline Imnaha Weir & 20,904 & $0.320(0.006)$ & $0.276(0.008)$ & $0.080(0.005)$ & $0.307(0.010)$ \\
\hline Lostine River Pond (3/17) & 2,667 & $0.307(0.014)$ & $0.215(0.015)$ & $0.062(0.009)$ & $0.301(0.023)$ \\
\hline Lostine River Pond (4/01) & 5,291 & $0.313(0.013)$ & $0.232(0.014)$ & $0.090(0.010)$ & $0.301(0.021)$ \\
\hline \multicolumn{6}{|c|}{ Pahsimeroi Hatchery } \\
\hline Pahsimeroi Trap & 982 & $0.271(0.088)$ & $0.155(0.069)$ & NA & NA \\
\hline \multicolumn{6}{|c|}{ Rapid River Hatchery } \\
\hline Rapid River H. & 51,762 & $0.341(0.004)$ & $0.266(0.005)$ & $0.063(0.003)$ & $0.345(0.007)$ \\
\hline \multicolumn{6}{|c|}{ Sawtooth Hatchery } \\
\hline Sawtooth Trap & 989 & $0.320(0.082)$ & $0.493(0.046)$ & $0.246(0.039)$ & $0.328(0.060)$ \\
\hline
\end{tabular}


Table 23. Estimated detection probabilities for PIT-tagged juvenile steelhead released from Snake River Basin hatcheries in 2003. Estimates based on the Single-Release Model. Standard errors in parentheses. Abbreviations: LGR-Lower Granite Dam; LGO-Little Goose Dam; LMO-Lower Monumental Dam; MCN-McNary Dam.

\begin{tabular}{lccccc}
\hline Release site & $\begin{array}{c}\text { Number } \\
\text { released }\end{array}$ & LGR & LGO & LMO & MCN \\
\hline \multicolumn{7}{c}{ Clearwater Hatchery } \\
S.F. Clearwater R. & 883 & $0.339(0.070)$ & $0.368(0.087)$ & $0.183(0.132)$ & $0.153(0.052)$ \\
Crooked River Pond & 648 & $0.295(0.032)$ & $0.319(0.040)$ & $0.323(0.058)$ & $0.167(0.058)$ \\
Red River Pond & 535 & $0.228(0.099)$ & $0.229(0.101)$ & $0.219(0.157)$ & $0.138(0.064)$ \\
Crooked River & 841 & $0.419(0.052)$ & $0.528(0.070)$ & $0.410(0.206)$ & $0.158(0.084)$ \\
Lolo Creek & 535 & $0.219(0.078)$ & $0.394(0.096)$ & NA & $0.083(0.056)$ \\
Meadow Creek & 525 & $0.252(0.048)$ & $0.264(0.068)$ & $0.445(0.124)$ & $0.154(0.100)$ \\
& & Dworshak Hatchery & & $0.307(0.032)$ & $0.147(0.028)$ \\
Dworshak H. & 1,500 & $0.303(0.018)$ & $0.331(0.022)$ &
\end{tabular}


Table 24. Estimated detection probabilities for PIT-tagged juvenile sockeye salmon from Sawtooth and Bonneville hatcheries and coho salmon from Kooskia and Clearwater hatcheries released in 2003. Estimates based on the Single-Release Model. Standard errors in parentheses. Abbreviations: LGR-Lower Granite Dam; LGO-Little Goose Dam; LMO-Lower Monumental Dam; MCN-McNary Dam.

\begin{tabular}{|c|c|c|c|c|c|c|}
\hline Release site & $\begin{array}{c}\text { Release } \\
\text { date }\end{array}$ & $\begin{array}{l}\text { Number } \\
\text { released }\end{array}$ & LGR & LGO & LMO & $\mathrm{MCN}$ \\
\hline \multicolumn{7}{|c|}{ Sawtooth Hatchery sockeye salmon } \\
\hline Pettit Lake & 08 Oct 02 & 2,013 & $0.294(0.019)$ & $0.484(0.026)$ & $0.212(0.026)$ & $0.211(0.033)$ \\
\hline Redfish Lake & 08 Oct 02 & 1,015 & $0.305(0.053)$ & $0.560(0.067)$ & $0.499(0.087)$ & $0.385(0.135)$ \\
\hline \multicolumn{7}{|c|}{ Bonneville Hatchery sockeye salmon } \\
\hline Alturus Lake & 27 Aug 02 & 1,481 & $0.080(0.054)$ & $0.500(0.125)$ & $0.200(0.126)$ & $0.667(0.192)$ \\
\hline Pettit Lake & 27 Aug 02 & 1,565 & $0.259(0.025)$ & $0.432(0.035)$ & $0.284(0.044)$ & $0.167(0.046)$ \\
\hline Redfish Lake & 29 Aug 02 & 1,007 & $0.220(0.065)$ & $0.462(0.089)$ & $0.423(0.128)$ & $0.500(0.177)$ \\
\hline \multicolumn{7}{|c|}{ Kooskia Hatchery coho salmon } \\
\hline Kooskia Hatchery & 10 Apr 03 & 1,000 & $0.259(0.021)$ & $0.411(0.028)$ & $0.181(0.026)$ & $0.138(0.026)$ \\
\hline \multicolumn{7}{|c|}{ Clearwater Hatchery coho salmon } \\
\hline S.F. Clearwater R. & $08 \mathrm{Jul} 02$ & 1,990 & $0.302(0.093)$ & $0.311(0.113)$ & $0.417(0.142)$ & $0.143(0.132)$ \\
\hline Eldorado Creek & $08 \mathrm{Jul} 02$ & 1,006 & $0.560(0.099)$ & $0.514(0.144)$ & $0.400(0.219)$ & $0.500(0.354)$ \\
\hline Meadow Creek & 08 Jul 02 & 996 & $0.500(0.125)$ & NA & NA & NA \\
\hline
\end{tabular}


Table 25. Estimated survival probabilities for juvenile salmonids released from fish traps in Snake River Basin in 2003.

Estimates based on the Single-Release Model. Standard errors in parentheses. Abbreviations: Rel-Release; LGR-Lower Granite Dam; LGO-Little Goose Dam; LMO-Lower Monumental Dam; MCN-McNary Dam.

\begin{tabular}{|c|c|c|c|c|c|c|c|}
\hline Trap & $\begin{array}{c}\text { Release } \\
\text { dates }\end{array}$ & $\begin{array}{l}\text { Number } \\
\text { released }\end{array}$ & $\begin{array}{c}\text { Rel } \\
\text { to } \mathrm{LGR}\end{array}$ & $\begin{array}{c}\text { LGR } \\
\text { to } \mathrm{LGO}\end{array}$ & $\begin{array}{c}\mathrm{LGO} \\
\text { to } \mathrm{LMO}\end{array}$ & $\begin{array}{c}\mathrm{LMO} \\
\text { to } \mathrm{MCN}\end{array}$ & $\begin{array}{c}\mathrm{Rel} \\
\text { to } \mathrm{MCN}\end{array}$ \\
\hline \multicolumn{8}{|c|}{ Wild chinook salmon } \\
\hline Snake & 24 Mar-27 May & 1,311 & $0.943(0.033)$ & $0.863(0.044)$ & $0.927(0.055)$ & $0.943(0.074)$ & $0.711(0.044)$ \\
\hline Clearwater & 19 Mar-15 May & 990 & $0.747(0.032)$ & $0.816(0.059)$ & $0.850(0.094)$ & $0.929(0.120)$ & $0.481(0.045)$ \\
\hline Grande Ronde (spring) & 10 Mar-31 May & 2,510 & $0.902(0.026)$ & $0.854(0.042)$ & $0.855(0.067)$ & $1.016(0.089)$ & $0.670(0.037)$ \\
\hline Grande Ronde (late) & 01 Jun-08 Jun & 162 & $0.769(0.066)$ & $0.887(0.120)$ & $0.719(0.118)$ & NA & NA \\
\hline Imnaha (spring) & 07 Mar-28 May & 5,097 & $0.775(0.012)$ & $0.921(0.022)$ & $0.872(0.035)$ & $1.004(0.047)$ & $0.625(0.020)$ \\
\hline Imnaha (late) & 04 Jun-25 Jun & 214 & $0.344(0.041)$ & $1.072(0.302)$ & $0.474(0.192)$ & NA & NA \\
\hline Salmon & 11 Mar-23 May & 9,242 & $0.807(0.011)$ & $0.890(0.021)$ & $0.896(0.039)$ & $0.958(0.046)$ & $0.617(0.017)$ \\
\hline Minam & 05 Mar-25 Apr & 512 & $0.455(0.037)$ & $0.871(0.102)$ & $0.983(0.190)$ & NA & NA \\
\hline Elgin (Grande Ronde R.) & 10 Apr-28 May & 249 & $0.773(0.056)$ & $0.876(0.108)$ & $0.825(0.139)$ & NA & NA \\
\hline Crooked River & 26 Mar-30 May & 387 & $0.334(0.040)$ & $0.728(0.119)$ & $1.330(0.402)$ & NA & NA \\
\hline American River (spring) & 28 Mar-31 May & 956 & $0.467(0.025)$ & $0.861(0.073)$ & $0.752(0.094)$ & $0.934(0.154)$ & $0.282(0.041)$ \\
\hline American River (late) & 01 Jun-30 Jun & 542 & $0.531(0.030)$ & $0.826(0.114)$ & $0.532(0.159)$ & $0.563(0.231)$ & $0.131(0.041)$ \\
\hline Lostine River & $26 \mathrm{Feb}-25 \mathrm{Apr}$ & 483 & $0.499(0.040)$ & $0.832(0.093)$ & NA & NA & NA \\
\hline Red River & 26 Mar-24 May & 691 & $0.328(0.023)$ & $0.859(0.090)$ & $0.748(0.123)$ & $0.992(0.255)$ & $0.209(0.047)$ \\
\hline Crooked Fork Creek & 20 Mar-19 May & 42 & $0.438(0.053)$ & $0.875(0.155)$ & $0.800(0.185)$ & $1.032(0.316)$ & $0.317(0.083)$ \\
\hline Catherine Creek & 13 Feb-20 May & 535 & $0.375(0.030)$ & $0.960(0.107)$ & $0.838(0.156)$ & NA & $0.425(0.104)$ \\
\hline Spoolcart (Grande Ronde) & 08 Mar-20 May & 571 & $0.391(0.027)$ & $0.929(0.073)$ & $1.082(0.134)$ & $0.963(0.170)$ & $0.379(0.053)$ \\
\hline Johnson Creek & 06 Mar-22 May & 2,361 & $0.392(0.013)$ & $0.977(0.039)$ & $0.920(0.053)$ & $0.845(0.065)$ & $0.298(0.019)$ \\
\hline South Fork Salmon R. & 06 Mar-16 May & 582 & $0.460(0.029)$ & $0.870(0.061)$ & $0.970(0.081)$ & $1.225(0.190)$ & $0.475(0.070)$ \\
\hline
\end{tabular}


Table 25. Continued.

\begin{tabular}{|c|c|c|c|c|c|c|c|}
\hline Trap & $\begin{array}{c}\text { Release } \\
\text { dates }\end{array}$ & $\begin{array}{l}\text { Number } \\
\text { released }\end{array}$ & $\begin{array}{c}\text { Rel } \\
\text { to } \mathrm{LGR} \\
\end{array}$ & $\begin{array}{c}\text { LGR } \\
\text { to } \mathrm{LGO}\end{array}$ & $\begin{array}{c}\mathrm{LGO} \\
\text { to } \mathrm{LMO}\end{array}$ & $\begin{array}{c}\mathrm{LMO} \\
\text { to } \mathrm{MCN}\end{array}$ & $\begin{array}{c}\text { Rel } \\
\text { to } \mathrm{MCN}\end{array}$ \\
\hline \multicolumn{8}{|c|}{ Wild chinook salmon (continued) } \\
\hline Lemhi River Weir (spring) & 07 Mar-31 May & 378 & $0.489(0.051)$ & $0.924(0.184)$ & $0.710(0.237)$ & $0.954(0.300)$ & $0.306(0.053)$ \\
\hline Lemhi River Weir (late) & 01 Jun-29 Jun & 98 & $0.418(0.138)$ & $0.281(0.147)$ & NA & NA & NA \\
\hline Pahsimeroi (spring) & 04 Mar-31 May & 2,476 & $0.576(0.025)$ & $0.838(0.061)$ & $0.817(0.099)$ & $0.979(0.144)$ & $0.386(0.038)$ \\
\hline Pahsimeroi (late) & 01 Jun-25 Aug & 807 & $0.353(0.025)$ & $0.850(0.142)$ & $0.390(0.102)$ & $0.778(0.213)$ & $0.091(0.022)$ \\
\hline Marsh Creek & 19 Mar-27 May & 627 & $0.487(0.034)$ & $0.831(0.080)$ & $0.961(0.129)$ & $0.830(0.144)$ & $0.323(0.042)$ \\
\hline East Fork Salmon & $11 \mathrm{Mar}$ & 64 & $0.273(0.062)$ & $1.157(0.328)$ & $0.576(0.251)$ & $0.686(0.272)$ & $0.125(0.049)$ \\
\hline Sawtooth & 19 Mar-24 May & 2,652 & $0.515(0.015)$ & $0.948(0.038)$ & $0.818(0.043)$ & $0.965(0.063)$ & $0.385(0.022)$ \\
\hline \multicolumn{8}{|c|}{ Wild steelhead } \\
\hline Snake & 24 Mar-27 May & 1,208 & $0.893(0.026)$ & $0.910(0.041)$ & $0.938(0.079)$ & $0.868(0.153)$ & $0.662(0.105)$ \\
\hline Clearwater & 19 Mar-15 May & 457 & $0.842(0.055)$ & $0.837(0.102)$ & $1.056(0.259)$ & $0.785(0.248)$ & $0.584(0.127)$ \\
\hline Grande Ronde (spring) & 20 Mar-31 May & 567 & $0.837(0.033)$ & $0.910(0.052)$ & $0.788(0.070)$ & $0.889(0.159)$ & $0.534(0.088)$ \\
\hline Grande Ronde (late) & 01 Jun-08 Jun & 45 & $0.613(0.082)$ & $1.036(0.168)$ & $0.905(0.470)$ & NA & NA \\
\hline Imnaha (spring) & 08 Mar-23 May & 6,168 & $0.826(0.013)$ & $0.905(0.023)$ & $0.918(0.037)$ & $0.675(0.039)$ & $0.463(0.022)$ \\
\hline Imnaha (late) & 03 Jun-20 Jun & 134 & $0.602(0.072)$ & $1.028(0.234)$ & $0.760(0.428)$ & $0.139(0.099)$ & $0.065(0.031)$ \\
\hline Salmon & 15 Mar-23 May & 312 & $0.952(0.092)$ & $0.603(0.087)$ & $0.957(0.189)$ & $0.978(0.361)$ & $0.537(0.178)$ \\
\hline Lookingglass Creek & 28 Jan-30 May & 779 & $0.469(0.031)$ & $0.954(0.093)$ & NA & NA & $0.207(0.064)$ \\
\hline Minam & 10 Mar-20 May & 503 & $0.668(0.041)$ & $0.931(0.088)$ & $0.785(0.114)$ & $0.691(0.181)$ & $0.337(0.079)$ \\
\hline Lostine River & 27 Feb-22 May & 451 & $0.705(0.040)$ & $0.975(0.076)$ & $0.883(0.124)$ & $1.443(0.652)$ & $0.877(0.380)$ \\
\hline Crooked Fork Creek & 21 Mar-14 May & 95 & $0.760(0.080)$ & $1.084(0.236)$ & $1.114(0.509)$ & $0.500(0.266)$ & $0.460(0.146)$ \\
\hline Catherine Creek & 13 Feb-32 May & 341 & $0.382(0.044)$ & $1.241(0.272)$ & $0.673(0.309)$ & $0.993(0.716)$ & $0.317(0.184)$ \\
\hline Spoolcart (Grande Ronde) & 07 Mar-30 May & 573 & $0.458(0.039)$ & $0.939(0.124)$ & $0.980(0.293)$ & $0.998(0.690)$ & $0.421(0.263)$ \\
\hline Johnson Creek & 06 Mar-22 May & 80 & $0.528(0.086)$ & NA & NA & NA & NA \\
\hline South Fork Salmon R. & 08 Mar-16 May & 168 & $0.071(0.043)$ & NA & NA & NA & NA \\
\hline
\end{tabular}


Table 25. Continued.

\begin{tabular}{|c|c|c|c|c|c|c|c|}
\hline Trap & $\begin{array}{c}\text { Release } \\
\text { dates }\end{array}$ & $\begin{array}{l}\text { Number } \\
\text { released }\end{array}$ & $\begin{array}{c}\text { Rel } \\
\text { to } \mathrm{LGR}\end{array}$ & $\begin{array}{c}\mathrm{LGR} \\
\text { to } \mathrm{LGO}\end{array}$ & $\begin{array}{c}\mathrm{LGO} \\
\text { to } \mathrm{LMO}\end{array}$ & $\begin{array}{c}\mathrm{LMO} \\
\text { to } \mathrm{MCN}\end{array}$ & $\begin{array}{c}\text { Rel } \\
\text { to } \mathrm{MCN}\end{array}$ \\
\hline \multicolumn{8}{|c|}{ Wild steelhead (continued) } \\
\hline Lemhi River Weir & 07 Mar-31 May & 169 & $0.160(0.116)$ & NA & NA & NA & NA \\
\hline Pahsimeroi & 04 Mar-31 May & 1,368 & $0.157(0.019)$ & $0.739(0.110)$ & NA & NA & $0.070(0.018)$ \\
\hline Sawtooth & 19 Mar-24 May & 390 & $0.315(0.031)$ & $1.189(0.198)$ & $0.646(0.175)$ & NA & NA \\
\hline \multicolumn{8}{|c|}{ Hatchery chinook salmon } \\
\hline Snake & 24 Mar-27 May & 2,073 & $1.000(0.030)$ & $0.813(0.035)$ & $0.926(0.053)$ & $0.894(0.064)$ & $0.674(0.035)$ \\
\hline Grande Ronde & 17 Mar-28 May & 1,396 & $0.858(0.037)$ & $0.871(0.070)$ & $0.910(0.127)$ & $0.896(0.129)$ & $0.609(0.048)$ \\
\hline Imnaha & 03 Apr-17 May & 47 & $0.768(0.129)$ & NA & NA & NA & NA \\
\hline Salmon & 13 Mar-22 May & 4,492 & $0.728(0.016)$ & $0.869(0.029)$ & $0.966(0.063)$ & $0.930(0.068)$ & $0.569(0.024)$ \\
\hline Lookingglass Creek & 28 Jan-15 Apr & 42 & $0.571(0.296)$ & $0.350(0.203)$ & NA & NA & NA \\
\hline South Fork Salmon & 08 Mar-16 May & 219 & $0.370(0.033)$ & NA & NA & NA & $0.195(0.068)$ \\
\hline \multicolumn{8}{|c|}{ Hatchery steelhead } \\
\hline Snake & 28 Mar-27 May & 4,177 & $0.946(0.018)$ & $.904(0.027)$ & $1.028(0.050)$ & $0.675(0.065)$ & $0.594(0.051)$ \\
\hline Grande Ronde (spring) & 27 Mar-31 May & 2,155 & $0.870(0.022)$ & $1.004(0.041)$ & $0.907(0.059)$ & $0.682(0.083)$ & $0.540(0.059)$ \\
\hline Grande Ronde (late) & 01 Jun-08 Jun & 55 & $0.998(0.092)$ & $0.654(0.104)$ & $1.159(0.630)$ & $0.208(0.137)$ & $0.157(0.060)$ \\
\hline Imnaha & 23 Mar-22 May & 5,225 & $0.892(0.017)$ & $0.986(0.029)$ & $0.938(0.038)$ & $0.766(0.062)$ & $0.631(0.046)$ \\
\hline Salmon & 02 Apr-23 May & 2,444 & $0.885(0.028)$ & $0.904(0.044)$ & $0.930(0.064)$ & $0.636(0.078)$ & $0.474(0.051)$ \\
\hline
\end{tabular}


Table 26. Estimated detection probabilities for juvenile salmonids released from fish traps in Snake River Basin in 2003.

Estimates based on the Single-Release Model. Standard errors in parentheses. Abbreviations: LGR-Lower Granite Dam; LGO-Little Goose Dam; LMO-Lower Monumental Dam; MCN-McNary Dam.

\begin{tabular}{|c|c|c|c|c|c|c|}
\hline Trap & $\begin{array}{c}\text { Release } \\
\text { dates }\end{array}$ & $\begin{array}{l}\text { Number } \\
\text { released }\end{array}$ & LGR & $\mathrm{LGO}$ & LMO & $\mathrm{MCN}$ \\
\hline \multicolumn{7}{|c|}{ Wild chinook salmon } \\
\hline Snake & 24 Mar-27 May & 1,311 & $0.324(0.017)$ & $0.452(0.021)$ & $0.341(0.024)$ & $0.414(0.032)$ \\
\hline Clearwater & 19 Mar-15 May & 990 & $0.453(0.025)$ & $0.452(0.032)$ & $0.217(0.030)$ & $0.425(0.046)$ \\
\hline Grande Ronde (spring) & 10 Mar-31 May & 2,510 & $0.356(0.014)$ & $0.387(0.018)$ & $0.148(0.015)$ & $0.429(0.027)$ \\
\hline Grande Ronde (late) & 01 Jun-08 Jun & 162 & $0.442(0.055)$ & $0.499(0.070)$ & $0.506(0.083)$ & $0.500(0.158)$ \\
\hline Imnaha (spring) & 07 Mar-28 May & 5,097 & $0.414(0.010)$ & $0.362(0.011)$ & $0.142(0.008)$ & $0.413(0.015)$ \\
\hline Imnaha (late) & 04 Jun-25 Jun & 214 & $0.665(0.074)$ & $0.312(0.101)$ & $0.333(0.118)$ & NA \\
\hline Salmon & 11 Mar-23 May & 9,242 & $0.419(0.008)$ & $0.376(0.009)$ & $0.134(0.007)$ & $0.434(0.014)$ \\
\hline Minam & $05 \mathrm{Mar}-25 \mathrm{Apr}$ & 512 & $0.408(0.042)$ & $0.456(0.052)$ & $0.282(0.062)$ & $0.316(0.087)$ \\
\hline Elgin (Grande Ronde R.) & 10 Apr-28 May & 249 & $0.467(0.047)$ & $0.414(0.056)$ & $0.287(0.059)$ & $0.349(0.081)$ \\
\hline Crooked River & 26 Mar-30 May & 387 & $0.442(0.061)$ & $0.506(0.071)$ & $0.269(0.095)$ & $0.286(0.171)$ \\
\hline American River (spring) & 28 Mar-31 May & 956 & $0.497(0.031)$ & $0.495(0.043)$ & $0.394(0.051)$ & $0.442(0.072)$ \\
\hline American River (late) & 01 Jun-30 Jun & 542 & $0.688(0.038)$ & $0.543(0.077)$ & $0.410(0.114)$ & $0.667(0.192)$ \\
\hline Lostine River & 26 Feb-25 Apr & 483 & $0.390(0.041)$ & $0.449(0.050)$ & $0.057(0.031)$ & $0.303(0.067)$ \\
\hline Red River & 26 Mar-24 May & 691 & $0.577(0.042)$ & $0.563(0.059)$ & $0.408(0.076)$ & $0.571(0.132)$ \\
\hline Crooked Fork Creek & 20 Mar-19 May & 42 & $0.438(0.065)$ & $0.476(0.084)$ & $0.417(0.104)$ & $0.462(0.138)$ \\
\hline Catherine Creek & 13 Feb-20 May & 535 & $0.429(0.043)$ & $0.416(0.053)$ & $0.236(0.054)$ & $0.237(0.067)$ \\
\hline Spoolcart (Grande Ronde) & 08 Mar-20 May & 571 & $0.425(0.038)$ & $0.475(0.045)$ & $0.277(0.048)$ & $0.366(0.063)$ \\
\hline
\end{tabular}


Table 26. Continued.

\begin{tabular}{|c|c|c|c|c|c|c|}
\hline Trap & $\begin{array}{c}\text { Release } \\
\text { dates }\end{array}$ & $\begin{array}{l}\text { Number } \\
\text { released }\end{array}$ & LGR & $\mathrm{LGO}$ & LMO & $\mathrm{MCN}$ \\
\hline \multicolumn{7}{|c|}{ Wild chinook salmon (continued) } \\
\hline Johnson Creek & 06 Mar-22 May & 2,361 & $0.420(0.019)$ & $0.494(0.023)$ & $0.409(0.028)$ & $0.468(0.036)$ \\
\hline South Fork Salmon R. & 06 Mar-16 May & 582 & $0.430(0.036)$ & $0.563(0.042)$ & $0.395(0.050)$ & $0.308(0.057)$ \\
\hline Lemhi River Weir (spring) & 07 Mar-31 May & 378 & $0.416(0.052)$ & $0.323(0.066)$ & $0.113(0.047)$ & $0.507(0.094)$ \\
\hline Lemhi River Weir (late) & 01 Jun-29 Jun & 98 & $0.512(0.176)$ & $0.778(0.204)$ & NA & NA \\
\hline Pahsimeroi (spring) & 04 Mar-31 May & 2,476 & $0.357(0.019)$ & $0.380(0.025)$ & $0.171(0.023)$ & $0.384(0.041)$ \\
\hline Pahsimeroi (late) & 01 Jun-25 Aug & 807 & $0.597(0.043)$ & $0.467(0.079)$ & $0.483(0.097)$ & $0.750(0.153)$ \\
\hline Marsh Creek & 19 Mar-27 May & 627 & $0.406(0.037)$ & $0.498(0.045)$ & $0.325(0.053)$ & $0.485(0.071)$ \\
\hline East Fork Salmon & $11 \mathrm{Mar}$ & 64 & $0.571(0.132)$ & $0.444(0.166)$ & $0.429(0.187)$ & $0.500(0.204)$ \\
\hline Sawtooth & 19 Mar-24 May & 2,652 & $0.394(0.016)$ & $0.471(0.020)$ & $0.377(0.023)$ & $0.430(0.029)$ \\
\hline \multicolumn{7}{|c|}{ Wild steelhead } \\
\hline Snake & 24 Mar-27 May & 1,208 & $0.368(0.018)$ & $0.497(0.023)$ & $0.305(0.028)$ & $0.141(0.025)$ \\
\hline Clearwater & 19 Mar-15 May & 457 & $0.434(0.037)$ & $0.418(0.048)$ & $0.176(0.047)$ & $0.261(0.065)$ \\
\hline Grande Ronde (spring) & 20 Mar-31 May & 567 & $0.419(0.027)$ & $0.529(0.033)$ & $0.439(0.042)$ & $0.196(0.039)$ \\
\hline Grande Ronde (late) & 01 Jun-08 Jun & 45 & $0.652(0.099)$ & $0.629(0.132)$ & $0.400(0.219)$ & NA \\
\hline Imnaha (spring) & 08 Mar-23 May & 6,168 & $0.363(0.009)$ & $0.369(0.010)$ & $0.286(0.012)$ & $0.243(0.014)$ \\
\hline Imnaha (late) & 03 Jun-20 Jun & 134 & $0.458(0.071)$ & $0.400(0.098)$ & $0.368(0.200)$ & $0.667(0.272)$ \\
\hline Salmon & 15 Mar-23 May & 312 & $0.340(0.043)$ & $0.378(0.051)$ & $0.280(0.059)$ & $0.172(0.063)$ \\
\hline Lookingglass Creek & 28 Jan-30 May & 779 & $0.380(0.032)$ & $0.494(0.046)$ & $0.287(0.074)$ & $0.182(0.067)$ \\
\hline Minam & 10 Mar-20 May & 503 & $0.384(0.033)$ & $0.476(0.045)$ & $0.447(0.063)$ & $0.191(0.057)$ \\
\hline Lostine River & 27 Feb-22 May & 451 & $0.365(0.032)$ & $0.543(0.043)$ & $0.368(0.056)$ & $0.070(0.034)$ \\
\hline
\end{tabular}


Table 26. Continued.

\begin{tabular}{|c|c|c|c|c|c|c|}
\hline Trap & $\begin{array}{c}\text { Release } \\
\text { dates }\end{array}$ & $\begin{array}{l}\text { Number } \\
\text { released }\end{array}$ & LGR & $\mathrm{LGO}$ & LMO & $\mathrm{MCN}$ \\
\hline \multicolumn{7}{|c|}{ Wild steelhead (continued) } \\
\hline Crooked Fork Creek & 21 Mar-14 May & 95 & $0.457(0.071)$ & $0.361(0.092)$ & $0.224(0.105)$ & $0.333(0.131)$ \\
\hline Catherine Creek & 13 Feb-32 May & 341 & $0.399(0.057)$ & $0.381(0.083)$ & $0.200(0.093)$ & $0.146(0.094)$ \\
\hline Spoolcart (Grande Ronde) & 07 Mar-30 May & 573 & $0.381(0.040)$ & $0.450(0.057)$ & $0.247(0.076)$ & $0.071(0.049)$ \\
\hline Johnson Creek & 06 Mar-22 May & 80 & $0.355(0.086)$ & NA & NA & NA \\
\hline South Fork Salmon R. & 08 Mar-16 May & 168 & $0.333(0.222)$ & NA & NA & NA \\
\hline Lemhi River Weir & 07 Mar-31 May & 169 & $0.259(0.201)$ & NA & NA & NA \\
\hline Pahsimeroi & 04 Mar-31 May & 1,368 & $0.297(0.044)$ & $0.532(0.058)$ & $0.228(0.075)$ & $0.320(0.093)$ \\
\hline Sawtooth & 19 Mar-24 May & 390 & $0.415(0.052)$ & $0.400(0.075)$ & $0.375(0.092)$ & NA \\
\hline \multicolumn{7}{|c|}{ Hatchery chinook salmon } \\
\hline Snake & 24 Mar-27 May & 2,073 & $0.275(0.013)$ & $0.371(0.016)$ & $0.201(0.014)$ & $0.375(0.023)$ \\
\hline Grande Ronde & 17 Mar-28 May & 1,396 & $0.330(0.019)$ & $0.201(0.018)$ & $0.076(0.013)$ & $0.373(0.033)$ \\
\hline Imnaha & 03 Apr-17 May & 47 & $0.360(0.096)$ & $0.250(0.097)$ & NA & $0.368(0.161)$ \\
\hline Salmon & 13 Mar-22 May & 4,492 & $0.342(0.011)$ & $0.307(0.012)$ & $0.092(0.008)$ & $0.339(0.017)$ \\
\hline Lookingglass Creek & $28 \mathrm{Jan}-15 \mathrm{Apr}$ & 42 & $0.250(0.153)$ & $0.833(0.152)$ & NA & NA \\
\hline South Fork Salmon & 08 Mar-16 May & 219 & $0.469(0.055)$ & $0.308(0.184)$ & $0.491(0.149)$ & $0.600(0.155)$ \\
\hline \multicolumn{7}{|c|}{ Hatchery steelhead } \\
\hline Snake & 28 Mar-27 May & 4,177 & $0.324(0.010)$ & $0.368(0.012)$ & $0.310(0.015)$ & $0.131(0.013)$ \\
\hline Grande Ronde (spring) & 27 Mar-31 May & 2,155 & $0.335(0.013)$ & $0.354(0.016)$ & $0.334(0.022)$ & $0.148(0.019)$ \\
\hline Grande Ronde (late) & 01 Jun-08 Jun & 55 & $0.601(0.086)$ & $0.823(0.093)$ & $0.286(0.171)$ & $0.500(0.204)$ \\
\hline Imnaha & 23 Mar-22 May & 5,225 & $0.271(0.008)$ & $0.300(0.010)$ & $0.331(0.013)$ & $0.112(0.010)$ \\
\hline Salmon & 02 Apr-23 May & 2,444 & $0.274(0.013)$ & $0.310(0.015)$ & $0.318(0.021)$ & $0.151(0.019)$ \\
\hline
\end{tabular}


Table 27. Estimated survival probabilities for PIT-tagged yearling chinook salmon and steelhead from upper-Columbia River hatcheries released in 2003. Estimates based on the Single-Release Model. Standard errors in parentheses. Abbreviations: Rel-Release site; MCN-McNary Dam; JDA-John Day Dam; BON-Bonneville Dam.

\begin{tabular}{|c|c|c|c|c|c|c|c|}
\hline Hatchery & $\begin{array}{r}\text { Release } \\
\text { Site }\end{array}$ & $\begin{array}{l}\text { Number } \\
\text { released }\end{array}$ & $\begin{array}{c}\text { Rel } \\
\text { to } \mathrm{MCN}\end{array}$ & $\begin{array}{l}\text { MCN } \\
\text { to JDA } \\
\end{array}$ & $\begin{array}{c}\text { JDA } \\
\text { to BON }\end{array}$ & $\begin{array}{c}\mathrm{MCN} \\
\text { to } \mathrm{BON}\end{array}$ & $\begin{array}{c}\text { Rel } \\
\text { to BON }\end{array}$ \\
\hline \multicolumn{8}{|c|}{ Yearling chinook salmon } \\
\hline Entiat & Entiat Hatchery & 59,879 & $0.655(0.010)$ & $0.874(0.029)$ & $0.978(0.090)$ & $0.854(0.076)$ & $0.559(0.049)$ \\
\hline Leavenworth & $\begin{array}{l}\text { Leavenworth } \\
\text { Hatchery }\end{array}$ & 240,556 & $0.637(0.003)$ & $0.933(0.010)$ & $0.958(0.042)$ & $0.894(0.039)$ & $0.569(0.024)$ \\
\hline Winthrop & Winthrop Hatchery & 19,962 & $0.553(0.014)$ & $0.830(0.047)$ & NA & NA & NA \\
\hline Methow & Methow Hatchery & 25,206 & $0.508(0.014)$ & $1.048(0.053)$ & $0.854(0.131)$ & $0.895(0.135)$ & $0.455(0.067)$ \\
\hline Methow & Chewuch Pond & 9,717 & $0.540(0.021)$ & $0.879(0.065)$ & $0.645(0.130)$ & $0.567(0.112)$ & $0.306(0.059)$ \\
\hline \multicolumn{8}{|c|}{ Steelhead } \\
\hline Wells & Wells Hatchery & 90,345 & $0.388(0.008)$ & $1.044(0.034)$ & $0.779(0.084)$ & $0.813(0.088)$ & $0.316(0.033)$ \\
\hline Wells & Twisp River & 25,893 & $0.437(0.015)$ & $1.086(0.060)$ & $0.734(0.124)$ & $0.799(0.133)$ & $0.349(0.057)$ \\
\hline Chelan & Nason Creek & 12,092 & $0.382(0.022)$ & $0.888(0.077)$ & $0.636(0.127)$ & $0.564(0.113)$ & $0.215(0.041)$ \\
\hline East Bank & Chiwawa River & 62,007 & $0.514(0.012)$ & $1.032(0.039)$ & $1.020(0.109)$ & $1.054(0.112)$ & $0.542(0.056)$ \\
\hline East Bank & Nason Creek & 21,062 & $0.434(0.018)$ & $0.965(0.061)$ & $0.690(0.105)$ & $0.666(0.101)$ & $0.289(0.042)$ \\
\hline Ringold & Ringold Hatchery & 95,159 & $0.673(0.014)$ & $0.962(0.028)$ & $0.875(0.081)$ & $0.842(0.079)$ & $0.567(0.052)$ \\
\hline Winthrop & Winthrop Hatchery & 49,947 & $0.310(0.010)$ & $0.969(0.052)$ & $0.857(0.118)$ & $0.830(0.113)$ & $0.258(0.034)$ \\
\hline
\end{tabular}


Table 28. Estimated detection probabilities for PIT-tagged yearling chinook salmon and steelhead from upper-Columbia River hatcheries released in 2003. Estimates based on the Single-Release Model. Standard errors in parentheses. Abbreviations: Rel-Release site; MCN-McNary Dam; JDA-John Day Dam; BON-Bonneville Dam.

\begin{tabular}{|c|c|c|c|c|c|}
\hline Hatchery & Release Site & $\begin{array}{l}\text { Number } \\
\text { released }\end{array}$ & $\mathrm{MCN}$ & JDA & $\mathrm{BON}$ \\
\hline \multicolumn{6}{|c|}{ Yearling chinook salmon } \\
\hline Entiat & Entiat Hatchery & 59,879 & $0.337(0.005)$ & $0.174(0.005)$ & $0.160(0.014)$ \\
\hline Leavenworth & Leavenworth Hatchery & 240,556 & $0.323(0.002)$ & $0.342(0.003)$ & $0.173(0.007)$ \\
\hline Winthrop & W inthrop Hatchery & 19,962 & $0.370(0.010)$ & $0.258(0.017)$ & $0.233(0.046)$ \\
\hline Methow & Methow Hatchery & 25,206 & $0.253(0.008)$ & $0.200(0.009)$ & $0.172(0.026)$ \\
\hline Methow & Chewuch Pond & 9,717 & $0.274(0.012)$ & $0.239(0.013)$ & $0.117(0.024)$ \\
\hline \multicolumn{6}{|c|}{ Steelhead } \\
\hline Wells & Wells Hatchery & 90,345 & $0.169(0.004)$ & $0.211(0.006)$ & $0.196(0.021)$ \\
\hline Wells & Twisp River & 25,893 & $0.190(0.007)$ & $0.198(0.009)$ & $0.217(0.036)$ \\
\hline Chelan & Nason Creek & 12,092 & $0.178(0.012)$ & $0.218(0.014)$ & $0.330(0.064)$ \\
\hline East Bank & Chiwawa River & 62,007 & $0.157(0.004)$ & $0.161(0.005)$ & $0.169(0.018)$ \\
\hline East Bank & Nason Creek & 21,062 & $0.179(0.008)$ & $0.190(0.010)$ & $0.287(0.042)$ \\
\hline Ringold & Ringold Hatchery & 95,159 & $0.107(0.003)$ & $0.210(0.004)$ & $0.186(0.017)$ \\
\hline Winthrop & W inthrop Hatchery & 49,947 & $0.175(0.007)$ & $0.177(0.008)$ & $0.182(0.024)$ \\
\hline
\end{tabular}


Table 29. Travel time statistics for Snake River yearling chinook salmon (hatchery and wild combined) detected and released to the tailrace at Lower Granite Dam in 2003. Abbreviations: LGR-Lower Granite Dam; LGO-Little Goose Dam; LMO-Lower Monumental Dam; MCN-McNary Dam; BON-Bonneville Dam; N-Number of fish on which statistics are based; Med.-Median.

\begin{tabular}{|c|c|c|c|c|c|c|c|c|c|c|c|c|}
\hline \multirow[b]{2}{*}{ Date at LGR } & \multicolumn{4}{|c|}{ LGR to LGO (days) } & \multicolumn{4}{|c|}{ LGO to LMO (days) } & \multicolumn{4}{|c|}{ LMO to MCN (days) } \\
\hline & $\mathrm{N}$ & $20 \%$ & Med. & $80 \%$ & $\mathrm{~N}$ & $20 \%$ & Med. & $80 \%$ & $\mathrm{~N}$ & $20 \%$ & Med. & $80 \%$ \\
\hline 30 Mar-05 Apr & 112 & 9.1 & 13.0 & 21.1 & 13 & 2.3 & 3.1 & 3.3 & 20 & 4.4 & 5.5 & 6.3 \\
\hline 06 Apr-12 Apr & 654 & 4.3 & 6.0 & 10.6 & 23 & 2.2 & 2.9 & 3.6 & 33 & 3.9 & 5.7 & 6.6 \\
\hline 20 Apr-26 Apr & 4,217 & 2.5 & 3.4 & 5.0 & 118 & 1.8 & 2.1 & 2.8 & 161 & 3.8 & 4.3 & 5.4 \\
\hline 27 Apr-03 May & 2,032 & 3.0 & 3.8 & 5.2 & 73 & 1.8 & 2.3 & 3.0 & 103 & 3.4 & 4.0 & 5.0 \\
\hline 04 May-10 May & 2,651 & 3.1 & 4.0 & 5.2 & 114 & 1.6 & 2.0 & 2.6 & 176 & 3.1 & 3.6 & 4.3 \\
\hline 18 May-24 May & 3,661 & 2.3 & 3.1 & 4.1 & 762 & 1.0 & 1.3 & 1.8 & 422 & 2.3 & 2.7 & 3.4 \\
\hline 25 May-31 May & 5,366 & 1.4 & 1.8 & 2.5 & 699 & 1.0 & 1.2 & 1.6 & 419 & 2.3 & 2.8 & 3.5 \\
\hline 01 Jun-07 Jun & 1,931 & 2.1 & 2.9 & 4.0 & 232 & 1.4 & 2.0 & 3.0 & 212 & 2.7 & 3.3 & 4.5 \\
\hline 08 Jun-14 Jun & 168 & 2.1 & 2.7 & 3.2 & 43 & 1.4 & 1.9 & 2.5 & 45 & 2.8 & 3.3 & 3.9 \\
\hline 15 Jun-21 Jun & 102 & 2.5 & 3.8 & 8.4 & 19 & 2.6 & 6.1 & 15.6 & 14 & 3.5 & 4.5 & 5.9 \\
\hline \multirow{2}{*}{22 Jun-28 Jun } & 143 & 3.4 & 6.0 & 12.5 & 29 & 3.8 & 9.4 & 18.6 & 17 & 4.0 & 5.2 & 6.3 \\
\hline & \multicolumn{4}{|c|}{ LGR to MCN(days) } & \multicolumn{4}{|c|}{ LGR to BON(days) } & & & & \\
\hline Date at LGR & $\mathrm{N}$ & $20 \%$ & Med. & $80 \%$ & $\mathrm{~N}$ & $20 \%$ & Med. & $80 \%$ & & & & \\
\hline 06 Apr-12 Apr & 404 & 13.1 & 15.3 & 19.6 & 168 & 22.1 & 24.8 & 29.1 & & & & \\
\hline 13 Apr-19 Apr & 1,878 & 10.4 & 12.0 & 14.8 & 629 & 18.3 & 20.4 & 23.1 & & & & \\
\hline 20 Apr-26 Apr & 3,704 & 8.1 & 9.7 & 11.9 & 1,224 & 14.4 & 16.6 & 20.3 & & & & \\
\hline 27 Apr-03 May & 1,910 & 8.3 & 9.7 & 11.3 & 756 & 14.4 & 16.2 & 18.4 & & & & \\
\hline 04 May-10 May & 2,827 & 8.1 & 9.2 & 10.6 & 1,220 & 13.3 & 15.0 & 16.8 & & & & \\
\hline 11 Мay-17 May & 2,282 & 6.9 & 8.0 & 9.1 & 877 & 11.5 & 12.6 & 14.2 & & & & \\
\hline 18 May-24 May & 1,175 & 6.4 & 7.2 & 8.5 & 524 & 10.1 & 11.3 & 12.8 & & & & \\
\hline 25 May-31 May & 1,385 & 4.8 & 5.8 & 7.0 & 1,122 & 8.5 & 9.6 & 11.0 & & & & \\
\hline 01 Jun-07 Jun & 707 & 6.9 & 9.0 & 13.2 & 259 & 10.4 & 12.2 & 15.7 & & & & \\
\hline 08 Jun-14 Jun & 184 & 6.9 & 8.1 & 9.8 & 49 & 11.2 & 13.0 & 14.3 & & & & \\
\hline 15 Jun-21 Jun & 41 & 8.0 & 11.4 & 21.8 & 5 & 12.0 & 13.2 & 20.2 & & & & \\
\hline 22 Jun-28 Jun & 38 & 16.7 & 23.2 & 30.5 & 4 & 22.9 & 24.2 & 26.4 & & & & \\
\hline
\end{tabular}


Table 30. Migration rate statistics for Snake River yearling chinook salmon (hatchery and wild combined) detected and released to the tailrace at Lower Granite Dam, 2003. Abbreviations: LGR-Lower Granite Dam; LGO-Little Goose Dam; LMO-Lower Monumental Dam; MCN-McNary Dam; BON-Bonneville Dam; N-Number of fish observed; Med-Median.

\begin{tabular}{|c|c|c|c|c|c|c|c|c|c|c|c|c|}
\hline \multirow[b]{2}{*}{ Date at LGR } & \multicolumn{4}{|c|}{ LGR to LGO (days) } & \multicolumn{4}{|c|}{ LGO to LMO (days) } & \multicolumn{4}{|c|}{ LMO to MCN (days) } \\
\hline & $\mathrm{N}$ & $20 \%$ & Med. & $80 \%$ & $\mathrm{~N}$ & $20 \%$ & Med. & $80 \%$ & $\mathrm{~N}$ & $20 \%$ & Med. & $80 \%$ \\
\hline 30 Mar-05 Apr & 112 & 2.8 & 4.6 & 6.6 & 13 & 14.1 & 15.0 & 20.1 & 20 & 19.0 & 21.6 & 26.7 \\
\hline 06 Apr-12 Apr & 654 & 5.7 & 9.9 & 13.9 & 23 & 12.9 & 15.9 & 21.1 & 33 & 17.9 & 21.0 & 30.3 \\
\hline 13 Apr-19 Apr & 2,621 & 7.8 & 11.3 & 14.6 & 116 & 13.6 & 18.5 & 22.0 & 138 & 21.8 & 26.6 & 31.8 \\
\hline 20 Apr-26 Apr & 4,217 & 11.9 & 17.7 & 23.6 & 118 & 16.3 & 21.5 & 26.0 & 161 & 22.2 & 27.6 & 31.2 \\
\hline 27 Apr-03 May & 2,032 & 11.6 & 15.6 & 19.7 & 73 & 15.5 & 20.0 & 24.9 & 103 & 24.0 & 29.5 & 34.7 \\
\hline 04 Мау-10 May & 2,651 & 11.5 & 14.9 & 19.5 & 114 & 17.8 & 22.4 & 28.9 & 176 & 27.9 & 33.5 & 37.9 \\
\hline 11 Маy-17 May & 3,121 & 16.5 & 21.4 & 28.7 & 208 & 20.0 & 24.6 & 33.1 & 188 & 27.4 & 32.9 & 39.3 \\
\hline 18 Мау-24 Маy & 3,661 & 14.6 & 19.2 & 26.5 & 762 & 25.1 & 35.4 & 43.8 & 422 & 34.8 & 44.4 & 51.3 \\
\hline 25 Маy-31 Маy & 5,366 & 24.4 & 33.5 & 42.9 & 699 & 28.2 & 38.0 & 46.9 & 419 & 33.6 & 43.3 & 52.2 \\
\hline 01 Jun-07 Jun & 1,931 & 15.0 & 21.0 & 29.0 & 232 & 15.5 & 23.5 & 31.9 & 212 & 26.7 & 36.3 & 43.4 \\
\hline 08 Jun-14 Jun & 168 & 18.6 & 21.9 & 28.8 & 43 & 18.4 & 23.8 & 33.3 & 45 & 30.4 & 35.8 & 41.8 \\
\hline 15 Jun-21 Jun & 102 & 7.2 & 15.8 & 24.3 & 19 & 3.0 & 7.6 & 18.0 & 14 & 20.2 & 26.4 & 34.3 \\
\hline \multirow[t]{2}{*}{22 Jun-28 Jun } & 143 & 4.8 & 9.9 & 17.5 & 29 & 2.5 & 4.9 & 12.0 & 17 & 18.9 & 23.1 & 29.4 \\
\hline & \multicolumn{4}{|c|}{ LGR to MCN (days) } & \multicolumn{4}{|c|}{ LGR to BON (days) } & & & & \\
\hline Date at LGR & $\mathrm{N}$ & $20 \%$ & Med. & $80 \%$ & $\mathrm{~N}$ & $20 \%$ & Med. & $80 \%$ & & & & \\
\hline 30 Mar-05 Apr & 145 & 8.1 & 10.2 & 12.9 & 59 & 13.7 & 15.7 & 17.5 & & & & \\
\hline 06 Apr-12 Apr & 404 & 11.5 & 14.7 & 17.2 & 168 & 15.8 & 18.6 & 20.8 & & & & \\
\hline 13 Apr-19 Apr & 1,878 & 15.2 & 18.7 & 21.7 & 629 & 20.0 & 22.7 & 25.2 & & & & \\
\hline 20 Apr-26 Apr & 3,704 & 18.9 & 23.2 & 27.7 & 1,224 & 22.7 & 27.8 & 32.1 & & & & \\
\hline 27 Apr-03 May & 1,910 & 19.9 & 23.2 & 27.0 & 756 & 25.1 & 28.4 & 32.0 & & & & \\
\hline 04 Маy-10 Маy & 2,827 & 21.3 & 24.6 & 27.8 & 1,220 & 27.4 & 30.7 & 34.8 & & & & \\
\hline 11 May-17 May & 2,282 & 24.6 & 28.2 & 32.5 & 877 & 32.5 & 36.5 & 40.2 & & & & \\
\hline 18 Маy-24 May & 1,175 & 26.6 & 31.1 & 35.3 & 524 & 35.9 & 40.9 & 45.7 & & & & \\
\hline 25 May-31 May & 1,385 & 32.0 & 39.1 & 47.1 & 1,122 & 41.8 & 48.2 & 54.0 & & & & \\
\hline 01 Jun-07 Jun & 707 & 17.0 & 25.1 & 32.6 & 259 & 29.3 & 37.7 & 44.3 & & & & \\
\hline 08 Jun-14 Jun & 184 & 23.0 & 27.9 & 32.7 & 49 & 32.3 & 35.3 & 41.0 & & & & \\
\hline 15 Jun-21 Jun & 41 & 10.3 & 19.7 & 28.1 & 5 & 22.8 & 35.0 & 38.5 & & & & \\
\hline 22 Jun-28 Jun & 38 & 7.4 & 9.7 & 13.5 & 4 & 17.4 & 19.1 & 20.1 & & & & \\
\hline
\end{tabular}


Table 31. Travel time statistics for Snake River yearling chinook salmon (hatchery and wild combined) detected and released to the tailrace at McNary Dam in 2003. Abbreviations: MCN-McNary Dam; JDA-John Day Dam; BON-Bonneville Dam; N-Number of fish on which statistics are based; Med.-Median.

\begin{tabular}{|c|c|c|c|c|c|c|c|c|c|c|c|c|}
\hline \multirow[b]{2}{*}{ Date at MCN } & \multicolumn{4}{|c|}{ MCN to JDA (days) } & \multicolumn{4}{|c|}{ JDA to BON (days) } & \multicolumn{4}{|c|}{$\mathrm{MCN}$ to BON (days) } \\
\hline & $\mathrm{N}$ & $20 \%$ & Med. & $80 \%$ & $\mathrm{~N}$ & $20 \%$ & Med. & $80 \%$ & $\mathrm{~N}$ & $20 \%$ & Med. & $80 \%$ \\
\hline 20 Apr-26 Apr & 237 & 4.6 & 5.8 & 8.2 & 52 & 2.2 & 2.4 & 2.8 & 288 & 7.2 & 8.4 & 10.4 \\
\hline 27 Apr-03 May & 1,540 & 4.0 & 4.8 & 6.2 & 276 & 2.1 & 2.3 & 2.7 & 1,537 & 5.7 & 6.7 & 8.4 \\
\hline 04 May-10 May & 2,407 & 3.8 & 4.6 & 6.0 & 355 & 2.0 & 2.2 & 2.7 & 2,146 & 5.4 & 6.4 & 7.9 \\
\hline 11 May-17 May & 3,731 & 3.2 & 3.8 & 4.9 & 529 & 2.0 & 2.2 & 2.6 & 2,608 & 5.0 & 5.6 & 6.7 \\
\hline 18 May-24 May & 3,373 & 3.2 & 3.8 & 4.7 & 579 & 1.8 & 2.1 & 2.4 & 2,201 & 4.6 & 5.4 & 6.4 \\
\hline 25 May-31 May & 2,515 & 2.4 & 2.8 & 3.4 & 385 & 1.6 & 1.8 & 2.1 & 867 & 4.0 & 4.4 & 5.0 \\
\hline 01 Jun-07 Jun & 637 & 2.3 & 2.8 & 3.2 & 185 & 1.7 & 1.9 & 2.2 & 616 & 4.1 & 4.4 & 5.1 \\
\hline
\end{tabular}


Table 32. Migration rate statistics for Snake River yearling chinook salmon (hatchery and wild combined) detected and released to the tailrace at McNary Dam in 2003. Abbreviations: MCN-McNary Dam; JDA-John Day Dam; BON-Bonneville Dam; N-Number of fish on which statistics are based; Med.-Median.

\begin{tabular}{|c|c|c|c|c|c|c|c|c|c|c|c|c|}
\hline \multirow[b]{2}{*}{ Date at MCN } & \multicolumn{4}{|c|}{ MCN to JDA (km/day) } & \multicolumn{4}{|c|}{ JDA to BON (km/day) } & \multicolumn{4}{|c|}{ MCN to BON (km/day) } \\
\hline & $\mathrm{N}$ & $20 \%$ & Med. & $80 \%$ & $\mathrm{~N}$ & $20 \%$ & Med. & $80 \%$ & $\mathrm{~N}$ & $20 \%$ & Med. & $80 \%$ \\
\hline 20 Apr-26 Apr & 237 & 14.9 & 21.3 & 26.5 & 52 & 40.2 & 46.3 & 52.3 & 288 & 22.8 & 28.2 & 32.9 \\
\hline 27Apr-03 May & 1,540 & 19.8 & 25.8 & 30.9 & 276 & 42.5 & 48.9 & 53.8 & 1,537 & 28.3 & 35.4 & 41.6 \\
\hline 04 May-10 May & 2,407 & 20.6 & 27.0 & 31.9 & 355 & 42.3 & 50.2 & 55.4 & 2,146 & 30.0 & 36.9 & 43.3 \\
\hline 11 May-17 May & 3,731 & 25.3 & 32.5 & 38.8 & 529 & 43.1 & 50.2 & 56.2 & 2,608 & 35.2 & 42.3 & 46.7 \\
\hline 18 May-24 May & 3,373 & 26.3 & 32.2 & 38.9 & 579 & 47.5 & 54.9 & 62.4 & 2,201 & 37.2 & 43.9 & 51.0 \\
\hline 25 May-31 May & 2,515 & 35.9 & 44.6 & 51.7 & 35 & 53.1 & 62.4 & 69.3 & 867 & 47.1 & 53.8 & 59.4 \\
\hline 01 Jun-07 Jun & 637 & 38.1 & 43.9 & 53.2 & 185 & 50.9 & 59.5 & 65.7 & 616 & 46.4 & 53.6 & 57.6 \\
\hline
\end{tabular}


Table 33. Travel time statistics for juvenile Snake River steelhead (hatchery and wild combined) detected and released to or PIT tagged and released to the tailrace at Lower Granite Dam in 2003. Abbreviations: LGR-Lower Granite Dam; LGO-Little Goose Dam; LMO-Lower Monumental Dam; MCN-McNary Dam; BON-Bonneville Dam; N-Number of fish on which statistics are based; Med.-Median.

\begin{tabular}{|c|c|c|c|c|c|c|c|c|c|c|c|c|}
\hline \multirow[b]{2}{*}{ Date at LGR } & \multicolumn{4}{|c|}{ LGR to LGO (days) } & \multicolumn{4}{|c|}{ LGO to LMO (days) } & \multicolumn{4}{|c|}{ LMO to MCN (days) } \\
\hline & $\mathrm{N}$ & $20 \%$ & Med. & $80 \%$ & $\mathrm{~N}$ & $20 \%$ & Med. & $80 \%$ & $\mathrm{~N}$ & $20 \%$ & Med. & $80 \%$ \\
\hline 30 Mar-05 Apr & 35 & 4.0 & 5.9 & 9.7 & 7 & 2.2 & 2.3 & 4.6 & 3 & 3.3 & 3.8 & 4.5 \\
\hline 06 Apr-12 Apr & 826 & 3.3 & 4.6 & 6.9 & 87 & 2.3 & 3.6 & 7.8 & 36 & 3.4 & 4.2 & 6.1 \\
\hline 13 Apr-19 Apr & 1,557 & 2.7 & 3.5 & 5.0 & 131 & 2.3 & 3.2 & 6.0 & 56 & 3.3 & 3.9 & 5.0 \\
\hline 20 Apr-26 Apr & 1,221 & 2.4 & 2.9 & 4.1 & 168 & 2.0 & 3.1 & 7.9 & 67 & 3.1 & 4.1 & 6.9 \\
\hline 27 Apr-03 May & 1,420 & 3.0 & 4.2 & 6.7 & 259 & 2.3 & 3.8 & 8.4 & 87 & 2.7 & 3.7 & 5.2 \\
\hline 04 May-10 May & 1,690 & 2.9 & 4.1 & 7.7 & 318 & 2.1 & 3.1 & 7.0 & 164 & 2.2 & 3.3 & 4.3 \\
\hline 11 May-17 May & 2,874 & 2.4 & 3.0 & 5.7 & 434 & 1.6 & 2.6 & 5.3 & 224 & 2.1 & 2.8 & 3.5 \\
\hline 18 May-24 May & 8,199 & 2.4 & 2.8 & 4.0 & 1,674 & 1.1 & 1.5 & 2.2 & 428 & 1.9 & 2.2 & 2.6 \\
\hline 25 May-31 May & 5,345 & 1.1 & 1.4 & 1.8 & 855 & 0.9 & 1.2 & 1.9 & 248 & 1.9 & 2.4 & 3.0 \\
\hline \multirow[t]{2}{*}{01 Jun-07 Jun } & 2,474 & 1.4 & 1.8 & 2.6 & 594 & 1.2 & 1.6 & 2.4 & 157 & 2.1 & 2.6 & 3.0 \\
\hline & \multicolumn{4}{|c|}{ LGR to MCN (days) } & \multicolumn{4}{|c|}{ LGR to BON (days) } & & & & \\
\hline Date at LGR & $\mathrm{N}$ & $20 \%$ & Med. & $80 \%$ & $\mathrm{~N}$ & $20 \%$ & Med. & $80 \%$ & & & & \\
\hline 30 Mar-05 Apr & 15 & 9.9 & 11.0 & 13.2 & 7 & 16.2 & 16.9 & 17.4 & & & & \\
\hline 06 Apr-12 Apr & 166 & 8.5 & 11.4 & 17.2 & 241 & 15.4 & 19.1 & 25.4 & & & & \\
\hline 13 Apr-19 Apr & 313 & 8.6 & 10.3 & 13.4 & 461 & 14.4 & 17.4 & 26.6 & & & & \\
\hline 20 Apr-26 Apr & 315 & 8.1 & 10.6 & 19.1 & 444 & 14.4 & 20.0 & 30.5 & & & & \\
\hline 27 Apr-03 May & 414 & 9.7 & 14.8 & 23.9 & 520 & 16.4 & 22.1 & 31.4 & & & & \\
\hline 04 Мау-10 May & 591 & 8.7 & 12.4 & 17.5 & 588 & 15.4 & 19.5 & 25.8 & & & & \\
\hline 11 May-17 May & 1,079 & 7.7 & 9.5 & 11.8 & 856 & 13.4 & 15.9 & 22.5 & & & & \\
\hline 18 May-24 May & 859 & 5.8 & 7.4 & 8.4 & 894 & 11.1 & 13.6 & 17.4 & & & & \\
\hline 25 May-31 May & 585 & 3.7 & 4.7 & 6.2 & 1,069 & 8.5 & 10.1 & 12.4 & & & & \\
\hline 01 Jun-07 Jun & 270 & 4.8 & 5.8 & 7.4 & 128 & 10.2 & 12.1 & 14.4 & & & & \\
\hline
\end{tabular}


Table 34. Migration rate statistics for juvenile Snake River steelhead (hatchery and wild combined) detected and released to or PIT tagged and released to the tailrace at Lower Granite Dam in 2003. Abbreviations: LGR-Lower Granite Dam; LGO-Little Goose Dam; LMO-Lower Monumental Dam; MCN-McNary Dam; BON-Bonneville Dam; N-Number of fish on which statistics are based; Med.-Median.

\begin{tabular}{|c|c|c|c|c|c|c|c|c|c|c|c|c|}
\hline \multirow[b]{2}{*}{ Date at LGR } & \multicolumn{4}{|c|}{ LGR to LGO (km/day) } & \multicolumn{4}{|c|}{ LGO to LMO (km/day) } & \multicolumn{4}{|c|}{ LMO to MCN (km/day) } \\
\hline & $\mathrm{N}$ & $20 \%$ & Med & $80 \%$ & $\mathrm{~N}$ & $20 \%$ & Med & $80 \%$ & $\mathrm{~N}$ & $20 \%$ & Med & $80 \%$ \\
\hline $30 \mathrm{Mar}-05 \mathrm{Apr}$ & 35 & 6.2 & 10.1 & 15.1 & 7 & 10.1 & 20.3 & 21.2 & 3 & 26.6 & 31.3 & 35.7 \\
\hline 06 Apr-12 Apr & 826 & 8.6 & 13.2 & 18.1 & 87 & 5.9 & 12.7 & 20.3 & 36 & 19.6 & 28.5 & 35.1 \\
\hline 13 Apr-19 Apr & 1,557 & 11.9 & 16.9 & 22.0 & 131 & 7.7 & 14.5 & 20.4 & 56 & 23.8 & 30.2 & 35.7 \\
\hline 20 Apr-26 Apr & 1,221 & 14.5 & 20.9 & 25.1 & 168 & 5.8 & 14.7 & 22.7 & 67 & 17.1 & 29.0 & 38.1 \\
\hline 27 Apr-03 May & 1,420 & 8.9 & 14.4 & 20.0 & 259 & 5.5 & 12.1 & 20.2 & 87 & 22.8 & 32.1 & 43.4 \\
\hline 04 May-10 May & 1,690 & 7.8 & 14.6 & 20.6 & 318 & 6.6 & 14.7 & 22.2 & 164 & 27.7 & 36.0 & 52.9 \\
\hline 11 May-17 May & 2,874 & 10.6 & 19.8 & 25.0 & 434 & 8.6 & 18.0 & 28.2 & 224 & 33.7 & 42.3 & 57.2 \\
\hline 18 Маy-24 May & 8,199 & 15.0 & 21.3 & 25.4 & 1,674 & 21.1 & 30.9 & 41.1 & 428 & 46.3 & 55.3 & 61.7 \\
\hline 25 May-31 May & 5,345 & 33.0 & 42.9 & 55.6 & 855 & 23.8 & 39.3 & 51.7 & 248 & 40.2 & 50.4 & 61.7 \\
\hline \multirow{2}{*}{01 Jun-07 Jun } & 2,474 & 23.0 & 33.7 & 43.2 & 594 & 18.9 & 28.4 & 39.0 & 157 & 39.5 & 46.7 & 55.6 \\
\hline & \multicolumn{4}{|c|}{ LGR to MCN (km/day) } & \multicolumn{4}{|c|}{ LGR to BON $(\mathrm{km} / \mathrm{day})$} & & & & \\
\hline Date at LGR & $\mathrm{N}$ & $20 \%$ & Med. & $80 \%$ & $\mathrm{~N}$ & $20 \%$ & Med. & $80 \%$ & & & & \\
\hline 30 Mar-05 Apr & 15 & 17.1 & 20.4 & 22.7 & 7 & 26.6 & 27.3 & 28.4 & & & & \\
\hline 06 Apr-12 Apr & 166 & 13.1 & 19.8 & 26.4 & 241 & 18.1 & 24.1 & 30.0 & & & & \\
\hline 13 Apr-19 Apr & 313 & 16.8 & 21.8 & 26.1 & 461 & 17.3 & 26.6 & 32.1 & & & & \\
\hline 20 Apr-26 Apr & 315 & 11.8 & 21.2 & 27.8 & 444 & 15.1 & 23.1 & 32.1 & & & & \\
\hline 27 Apr-03 May & 414 & 9.4 & 15.2 & 23.1 & 520 & 14.7 & 20.9 & 28.1 & & & & \\
\hline 04 May-10 May & 591 & 12.8 & 18.1 & 25.8 & 588 & 17.9 & 23.7 & 29.9 & & & & \\
\hline 11 May-17 May & 1,079 & 19.0 & 23.6 & 29.3 & 856 & 20.5 & 29.0 & 34.4 & & & & \\
\hline 18 Маy-24 Мay & 859 & 26.7 & 30.6 & 38.7 & 894 & 26.4 & 34.0 & 41.6 & & & & \\
\hline 25 May-31 May & 585 & 36.2 & 47.8 & 60.5 & 1,069 & 37.1 & 45.8 & 54.4 & & & & \\
\hline 01 Jun-07 Jun & 270 & 30.4 & 39.0 & 46.7 & 128 & 32.0 & 38.0 & 45.4 & & & & \\
\hline
\end{tabular}


Table 35. Travel time statistics for juvenile Snake River steelhead (hatchery and wild combined) detected and released to or PIT tagged and released to the tailrace at McNary Dam in 2003. Abbreviations: MCN-McNary Dam; JDA-John Day Dam; BON-Bonneville Dam; N-Number of fish on which statistics are based; Med.-Median.

\begin{tabular}{|c|c|c|c|c|c|c|c|c|c|c|c|c|}
\hline \multirow[b]{2}{*}{ Date at $\mathrm{MCN}$} & \multicolumn{4}{|c|}{ MCN to JDA (days) } & \multicolumn{4}{|c|}{ JDA to BON (days) } & \multicolumn{4}{|c|}{$\mathrm{MCN}$ to BON (days) } \\
\hline & $\mathrm{N}$ & $20 \%$ & Med & $80 \%$ & $\mathrm{~N}$ & $20 \%$ & Med & $80 \%$ & $\mathrm{~N}$ & $20 \%$ & Med & $80 \%$ \\
\hline 27 Apr-03 May & 60 & 3.5 & 4.6 & 6.2 & 10 & 1.9 & 2.1 & 2.3 & 89 & 5.4 & 5.9 & 7.4 \\
\hline 04 May-10 May & 29 & 3.6 & 4.3 & 8.4 & 5 & 2.2 & 2.3 & 2.8 & 59 & 5.4 & 6.3 & 8.4 \\
\hline 11 May-17 May & 39 & 3.4 & 4.5 & 6.4 & 4 & 2.0 & 2.2 & 2.7 & 64 & 4.4 & 5.8 & 8.3 \\
\hline 18 May-24 May & 162 & 3.4 & 4.0 & 5.2 & 29 & 1.5 & 1.6 & 1.9 & 185 & 4.8 & 5.4 & 6.4 \\
\hline 25 May-31 May & 544 & 2.4 & 2.8 & 3.6 & 105 & 1.4 & 1.5 & 1.7 & 421 & 3.9 & 4.4 & 6.2 \\
\hline 01 Jun-07 Jun & 81 & 2.7 & 3.4 & 4.6 & 24 & 1.5 & 1.7 & 2.0 & 212 & 4.4 & 5.4 & 7.0 \\
\hline
\end{tabular}


Table 36. Migration rate statistics for juvenile Snake River steelhead (hatchery and wild combined) detected and released to or PIT tagged and released to the tailrace at McNary Dam in 2003. Abbreviations: MCN-McNary Dam; JDA-John Day Dam; BON-Bonneville Dam; N-Number of fish on which statistics are based; Med.-Median.

\begin{tabular}{|c|c|c|c|c|c|c|c|c|c|c|c|c|}
\hline \multirow{2}{*}{$\begin{array}{l}\text { Date } \\
\text { at MCN }\end{array}$} & \multicolumn{4}{|c|}{$\begin{array}{c}\text { MCN to JDA } \\
(\mathrm{km} / \text { day })\end{array}$} & \multicolumn{4}{|c|}{$\begin{array}{c}\text { JDA to BON } \\
(\mathrm{km} / \text { day })\end{array}$} & \multicolumn{4}{|c|}{$\begin{array}{c}\mathrm{MCN} \text { to } \mathrm{BON} \\
(\mathrm{km} / \text { day })\end{array}$} \\
\hline & $\mathrm{N}$ & $20 \%$ & Med. & $80 \%$ & $\mathrm{~N}$ & $20 \%$ & Med. & $80 \%$ & $\mathrm{~N}$ & $20 \%$ & Med. & $80 \%$ \\
\hline 27 Apr-03 May & 60 & 19.8 & 27.0 & 35.0 & 10 & 49.1 & 53.3 & 58.9 & 89 & 32.0 & 40.0 & 44.1 \\
\hline 04 May-10 May & 29 & 14.7 & 28.9 & 34.6 & 5 & 40.8 & 49.3 & 52.1 & 59 & 28.1 & 37.2 & 43.9 \\
\hline 11 May-17 May & 39 & 19.4 & 27.3 & 36.2 & 4 & 41.2 & 51.8 & 57.4 & 64 & 28.3 & 40.5 & 53.3 \\
\hline 18 May-24 May & 162 & 23.8 & 30.4 & 36.3 & 29 & 59.8 & 69.3 & 76.9 & 185 & 37.0 & 43.8 & 48.8 \\
\hline 25 May-31 May & 544 & 34.0 & 43.9 & 52.1 & 105 & 65.7 & 74.3 & 83.1 & 421 & 37.9 & 53.8 & 60.7 \\
\hline 01 Jun-07 Jun & 81 & 26.7 & 35.9 & 46.2 & 24 & 57.9 & 66.1 & 73.9 & 212 & 33.9 & 43.7 & 53.5 \\
\hline
\end{tabular}


Table 37. Number of PIT-tagged hatchery juvenile steelhead released at Lower Granite by day for survival estimates in 2003. Also included are tagging mortalities and lost tags by date.

\begin{tabular}{|c|c|c|c|c|c|c|c|}
\hline Release date & $\begin{array}{l}\text { Number } \\
\text { released }\end{array}$ & Mortalities & $\begin{array}{l}\text { Lost } \\
\text { Tags }\end{array}$ & $\begin{array}{l}\text { Release } \\
\text { date }\end{array}$ & $\begin{array}{l}\text { Number } \\
\text { released }\end{array}$ & Mortalities & $\begin{array}{l}\text { Lost } \\
\text { Tags }\end{array}$ \\
\hline 9 Apr & 174 & 0 & 1 & 09 May & 734 & 0 & 1 \\
\hline $10 \mathrm{Apr}$ & 175 & 0 & 0 & 10 May & 733 & 1 & 1 \\
\hline $11 \mathrm{Apr}$ & 349 & 0 & 1 & 13 May & 664 & 0 & 1 \\
\hline 12 Apr & 350 & 0 & 0 & 14 May & 664 & 0 & 0 \\
\hline $15 \mathrm{Apr}$ & 153 & 0 & 0 & 15 May & 661 & 1 & 3 \\
\hline $16 \mathrm{Apr}$ & 403 & 0 & 3 & 16 May & 662 & 1 & 1 \\
\hline 17 Apr & 279 & 0 & 1 & 17 May & 660 & 1 & 4 \\
\hline $18 \mathrm{Apr}$ & 278 & 0 & 2 & 20 May & 972 & 3 & 5 \\
\hline 19 Apr & 277 & 1 & 1 & 22 May & 487 & 1 & 2 \\
\hline $22 \mathrm{Apr}$ & 348 & 0 & 2 & 23 May & 485 & 2 & 4 \\
\hline $23 \mathrm{Apr}$ & 350 & 0 & 0 & 24 May & 486 & 3 & 0 \\
\hline $24 \mathrm{Apr}$ & 346 & 0 & 3 & 27 May & 346 & 3 & 1 \\
\hline $25 \mathrm{Apr}$ & 349 & 0 & 1 & 28 May & 342 & 2 & 6 \\
\hline $26 \mathrm{Apr}$ & 349 & 0 & 1 & 29 May & 346 & 1 & 3 \\
\hline 29 Apr & 696 & 1 & 3 & 30 May & 347 & 0 & 3 \\
\hline $30 \mathrm{Apr}$ & 698 & 1 & 1 & 31 May & 346 & 1 & 3 \\
\hline 01 May & 696 & 0 & 4 & 03 Jun & 208 & 0 & 2 \\
\hline 02 May & 700 & 0 & 1 & 04 Jun & 207 & 0 & 2 \\
\hline 03 May & 694 & 0 & 6 & 05 Jun & 207 & 1 & 2 \\
\hline 06 May & 732 & 1 & 2 & 06 Jun & 210 & 0 & 0 \\
\hline 07 May & 734 & 0 & 1 & 07 Jun & 210 & 0 & 0 \\
\hline 08 May & 733 & 0 & 2 & Total & 19,840 & 25 & 80 \\
\hline
\end{tabular}


Table 38. Estimated survival for yearling chinook salmon from selected Snake River Basin hatcheries to the tailrace of Lower Granite Dam, 1993-2003. Distance from each hatchery to Lower Granite Dam in parentheses in header. Standard errors in parentheses following each survival estimate.

\begin{tabular}{|c|c|c|c|c|c|c|c|c|}
\hline Year & Dworshak (116) & $\begin{array}{c}\text { Kooskia } \\
(176)\end{array}$ & $\begin{array}{c}\text { Lookingglass* } \\
\text { (209) }\end{array}$ & $\begin{array}{l}\text { Rapid River } \\
\text { (283) }\end{array}$ & $\begin{array}{c}\text { McCall } \\
(457)\end{array}$ & $\begin{array}{c}\text { Pahsimeroi } \\
\text { (630) }\end{array}$ & $\begin{array}{l}\text { Sawtooth } \\
\text { (747) }\end{array}$ & Mean \\
\hline 1993 & $0.647(0.028)$ & $0.689(0.047)$ & $0.660(0.025)$ & $0.670(0.017)$ & $0.498(0.017)$ & $0.456(0.032)$ & $0.255(0.023)$ & $0.554(0.060)$ \\
\hline 1994 & $0.778(0.020)$ & $0.752(0.053)$ & $0.685(0.021)$ & $0.526(0.024)$ & $0.554(0.022)$ & $0.324(0.028)$ & $0.209(0.014)$ & $0.547(0.081)$ \\
\hline 1995 & $0.838(0.034)$ & $0.786(0.024)$ & $0.617(0.015)$ & $0.726(0.017)$ & $0.522(0.011)$ & $0.316(0.033)$ & $0.230(0.015)$ & $0.576(0.088)$ \\
\hline 1996 & $0.776(0.017)$ & $0.744(0.010)$ & $0.567(0.014)$ & $0.588(0.007)$ & $0.531(0.007)$ & - & $0.121(0.017)$ & $0.555(0.096)$ \\
\hline 1997 & $0.576(0.017)$ & $0.449(0.034)$ & $0.616(0.017)$ & $0.382(0.008)$ & $0.424(0.008)$ & $0.500(0.008)$ & $0.508(0.037)$ & $0.494(0.031)$ \\
\hline 1998 & $0.836(0.006)$ & $0.652(0.024)$ & $0.682(0.006)$ & $0.660(0.004)$ & $0.585(0.004)$ & $0.428(0.021)$ & $0.601(0.033)$ & $0.635(0.046)$ \\
\hline 1999 & $0.834(0.011)$ & $0.653(0.031)$ & $0.668(0.009)$ & $0.746(0.006)$ & $0.649(0.008)$ & $0.584(0.035)$ & $0.452(0.019)$ & $0.655(0.045)$ \\
\hline 2000 & $0.841(0.009)$ & $0.734(0.027)$ & $0.688(0.011)$ & $0.748(0.007)$ & $0.689(0.010)$ & $0.631(0.062)$ & $0.546(0.030)$ & $0.697(0.035)$ \\
\hline 2001 & $0.747(0.002)$ & $0.577(0.019)$ & $0.747(0.003)$ & $0.689(0.002)$ & $0.666(0.002)$ & $0.621(0.016)$ & $0.524(0.023)$ & $0.653(0.032)$ \\
\hline 2002 & $0.819(0.011)$ & $0.787(0.036)$ & $0.667(0.012)$ & $0.755(0.003)$ & $0.592(0.006)$ & $0.678(0.053)$ & $0.387(0.025)$ & $0.669(0.055)$ \\
\hline 2003 & $\underline{0.720(0.008)}$ & $\underline{0.560(0.043)}$ & $\underline{0.715(0.012)}$ & $\underline{0.691(0.007)}$ & $\underline{0.573(0.006)}$ & $\underline{0.721(0.230)}$ & $\underline{0.595(0.149)}$ & $\underline{0.654(0.028)}$ \\
\hline Mean & $0.765(0.026)$ & $0.671(0.032)$ & $0.665(0.015)$ & $0.653(0.034)$ & $0.571(0.024)$ & $0.526(0.045)$ & $0.403(0.052)$ & \\
\hline
\end{tabular}

* Released at Imnaha River Weir. 
Table 39. Annual weighted means of survival probability estimates for yearling chinook salmon (hatchery and wild combined), 1993-2003. Standard errors in parentheses. Reaches with asterisks comprise two dams and reservoirs (i.e., two projects); the following column gives the square root (i.e., geometric mean) of the two-project estimate to facilitate comparison with other single-project estimates. Simple arithmetic means across all years, and across all years excluding 2001 are given. Abbreviations: SNKTRP-Snake River Trap; LGR-Lower Granite Dam; LGO-Little Goose Dam; LMO-Lower Monumental Dam; IHR-Ice Harbor Dam; MCN-McNary Dam; JDA-John Day Dam; TDA-THe Dalles Dam; BON-Bonneville Dam.

\begin{tabular}{|c|c|c|c|c|c|c|c|c|}
\hline Year & SNKTRP-LGR & LGR-LGO & LGO-LMO & LMO-MCN* & $\begin{array}{l}\text { LMO-IHR } \\
\text { IHR-MCN }\end{array}$ & MCN-JDA & JDA-BON* & $\begin{array}{l}\text { JDA-TDA } \\
\text { TDA-BON }\end{array}$ \\
\hline 1993 & $0.828(0.013)$ & $0.854(0.012)$ & & & & & & \\
\hline 1994 & $0.935(0.023)$ & $0.830(0.009)$ & $0.847(0.010)$ & & & & & \\
\hline 1995 & $0.905(0.010)$ & $0.882(0.004)$ & $0.925(0.008)$ & $0.876(0.038)$ & 0.936 & & & \\
\hline 1996 & $0.977(0.025)$ & $0.926(0.006)$ & $0.929(0.011)$ & $0.756(0.033)$ & 0.870 & & & \\
\hline 1997 & NA & $0.942(0.018)$ & $0.894(0.042)$ & $0.798(0.091)$ & 0.893 & & & \\
\hline 1998 & $0.925(0.009)$ & $0.991(0.006)$ & $0.853(0.009)$ & $0.915(0.011)$ & 0.957 & $0.822(0.033)$ & & \\
\hline 1999 & $0.940(0.009)$ & $0.949(0.002)$ & $0.925(0.004)$ & $0.904(0.007)$ & 0.951 & $0.853(0.027)$ & $0.814(0.065)$ & 0.902 \\
\hline 2000 & $0.929(0.014)$ & $0.938(0.006)$ & $0.887(0.009)$ & $0.928(0.016)$ & 0.963 & $0.898(0.054)$ & $0.684(0.128)$ & 0.827 \\
\hline 2001 & $0.954(0.015)$ & $0.945(0.004)$ & $0.830(0.006)$ & $0.708(0.007)$ & 0.841 & $0.758(0.024)$ & $0.645(0.034)$ & 0.803 \\
\hline 2002 & $0.953(0.022)$ & $0.949(0.006)$ & $0.980(0.008)$ & $0.837(0.013)$ & 0.915 & $0.907(0.014)$ & $0.840(0.079)$ & 0.917 \\
\hline 2003 & $0.993(0.023)$ & $0.946(0.005)$ & $0.916(0.011)$ & $0.904(0.017)$ & 0.951 & $0.893(0.017)$ & $0.818(0.036)$ & 0.904 \\
\hline Mean & $0.934(0.014)$ & $0.923(0.014)$ & $0.899(0.014)$ & $0.847(0.026)$ & $0.920(0.014)$ & $0.855(0.023)$ & $0.760(0.040)$ & $0.871(0.023)$ \\
\hline \multicolumn{2}{|c|}{ exc. 2001} & $0.921(0.016)$ & $0.906(0.014)$ & $0.865(0.022)$ & $0.930(0.012)$ & $0.875(0.016)$ & $0.789(0.035)$ & $0.888(0.020)$ \\
\hline \multicolumn{2}{|c|}{$0.932(0.016)$} & & & & & & & \\
\hline
\end{tabular}


Table 40. Annual weighted means of survival probability estimates for steelhead (hatchery and wild combined), 1994-2003. Standard errors in parentheses. Reaches with asterisks comprise two dams and reservoirs (i.e., two projects); the following column gives the square root (i.e., geometric mean) of the two-project estimate to facilitate comparison with other single-project estimates. Simple arithmetic means across all years, and across all years excluding 2001 are given. Abbreviations: SNKTRP-Snake River Trap; LGR-Lower Granite Dam; LGO-Little Goose Dam; LMO-Lower Monumental Dam; IHR-Ice Harbor Dam; MCN-McNary Dam; JDA-John Day Dam; TDA-THe Dalles Dam; BON-Bonneville Dam.

\begin{tabular}{|c|c|c|c|c|c|c|c|c|}
\hline Year & SNKTRP-LGR & LGR-LGO & LGO-LMO & LMO-MCN* & $\begin{array}{l}\text { LMO-IHR } \\
\text { IHR-MCN }\end{array}$ & MCN-JDA & JDA-BON* & $\begin{array}{c}\text { DA-TDA } \\
\text { TDA-BON }\end{array}$ \\
\hline 1993 & $0.905(0.006)$ & & & & & & & \\
\hline 1994 & NA & $0.844(0.011)$ & $0.892(0.011)$ & & & & & \\
\hline 1995 & $0.945(0.008)$ & $0.899(0.005)$ & $0.962(0.011)$ & $0.858(0.076)$ & 0.926 & & & \\
\hline 1996 & $0.951(0.015)$ & $0.938(0.008)$ & $0.951(0.014)$ & $0.791(0.052)$ & 0.889 & & & \\
\hline 1997 & $0.964(0.015)$ & $0.966(0.006)$ & $0.902(0.020)$ & $0.834(0.065)$ & 0.913 & & & \\
\hline 1998 & $0.924(0.009)$ & $0.930(0.004)$ & $0.889(0.006)$ & $0.797(0.018)$ & 0.893 & $0.831(0.031)$ & $0.935(0.103)$ & .967 \\
\hline 1999 & $0.908(0.011)$ & $0.926(0.004)$ & $0.915(0.006)$ & $0.833(0.011)$ & 0.913 & $0.920(0.033)$ & $0.682(0.039)$ & .826 \\
\hline 2000 & $0.964(0.013)$ & $0.901(0.006)$ & $0.904(0.009)$ & $0.842(0.016)$ & 0.918 & $0.851(0.045)$ & $0.754(0.045)$ & .868 \\
\hline 2001 & $0.911(0.007)$ & $0.801(0.010)$ & $0.709(0.008)$ & $0.296(0.010)$ & 0.544 & $0.337(0.025)$ & $0.753(0.063)$ & .868 \\
\hline 2002 & $0.895(0.015)$ & $0.882(0.011)$ & $0.882(0.018)$ & $0.652(0.031)$ & 0.807 & $0.844(0.063)$ & $0.612(0.098)$ & .782 \\
\hline 2003 & $0.932(0.015)$ & $0.947(0.005)$ & $0.898(0.012)$ & $0.708(0.018)$ & 0.841 & $0.879(0.032)$ & $0.630(0.066)$ & .794 \\
\hline Mean & $0.930(0.008)$ & $0.903(0.016)$ & $0.890(0.022)$ & $0.734(0.059)$ & $0.849(0.040)$ & $0.777(0.089)$ & $0.728(0.048)$ & $0.851(0.027)$ \\
\hline exc. 200 & $10.932(0.009)$ & $0.915(0.012)$ & $0.910(0.009)$ & $0.789(0.026)$ & $0.888(0.015)$ & $0.865(0.016)$ & $0.723(0.059)$ & $0.847(0.033)$ \\
\hline
\end{tabular}


Table 41. Hydropower system survival estimates derived by combining empirical survival estimates from various reaches for Snake River yearling chinook salmon and steelhead (hatchery and wild combined), 1997-2003. Standard errors in parentheses. Abbreviations: Trap-Snake River Trap; LGR-Lower Granite Dam; BON-Bonneville Dam.

\begin{tabular}{|c|c|c|c|c|c|c|}
\hline \multirow[b]{2}{*}{ Year } & \multicolumn{3}{|c|}{ Yearling chinook salmon } & \multicolumn{3}{|c|}{ Steelhead } \\
\hline & Trap-LGR & LGR-BON & Trap-BON & Trap-LGR & LGR-BON & Trap-BON \\
\hline 1997 & NA & NA & NA & $0.964(0.015)$ & $0.474(0.069)$ & $0.457(0.067)$ \\
\hline 1998 & $0.925(0.009)$ & NA & NA & $0.924(0.009)$ & $0.500(0.054)$ & $0.462(0.050)$ \\
\hline 1999 & $0.940(0.009)$ & $0.557(0.046)$ & $0.524(0.043)$ & $0.908(0.011)$ & $0.440(0.018)$ & $0.400(0.016)$ \\
\hline 2000 & $0.929(0.014)$ & $0.486(0.093)$ & $0.452(0.087)$ & $0.964(0.013)$ & $0.393(0.034)$ & $0.379(0.032)$ \\
\hline 2001 & $0.954(0.015)$ & $0.279(0.016)$ & $0.266(0.015)$ & $0.911(0.007)$ & $0.042(0.003)$ & $0.038(0.003)$ \\
\hline 2002 & $0.953(0.022)$ & $0.578(0.060)$ & $0.551(0.057)$ & $0.895(0.015)$ & $0.262(0.050)$ & $0.234(0.045)$ \\
\hline 2003 & $0.993(0.023)$ & $0.532(0.023)$ & $0.528(0.023)$ & $0.932(0.015)$ & $0.309(0.011)$ & $0.288(0.011)$ \\
\hline
\end{tabular}


Table 42. Average survival estimates (with standard errors in parentheses) from point of release to Bonneville Dam tailrace for various spring-migrating salmonid stocks in 2003. For each reach, the survival estimate represents a weighted average of daily or weekly estimates (some of which are presented in other tables in this document). In some cases, fish from separate release sites were pooled at downstream sites so survival estimates were identical. Dam release sites are in tailraces. Abbreviations: RLS-release site; MCN-McNary Dam; JDA-John Day Dam; BON-Bonneville Dam; SP-spring chinook salmon; SP-SU-spring-summer; S-F-summer-fall chinook salmon.

\begin{tabular}{llccccc}
\hline & & \multicolumn{5}{c}{ Survival Estimates (standard errors) } \\
\cline { 3 - 7 } Stock & Release Location & RLS-MCN & MCN-JDA & RLS-JDA & JDA-BON & RLS-BON \\
\hline Snake R. chinook (SP-SU) & Lower Granite Dam & $0.731(0.010)$ & $0.893(0.017)$ & $0.652(0.015)$ & $0.818(0.036)$ & $0.532(0.023)$ \\
U. Columbia chinook (S-F) & Rocky Reach Dam & $0.750(0.013)$ & $0.891(0.043)$ & $0.668(0.034)$ & $0.820(0.097)$ & $0.550(0.057)$ \\
U. Columbia chinook (S-F) & Rock Island Dam & $0.815(0.012)$ & $0.891(0.043)$ & $0.726(0.037)$ & $0.820(0.097)$ & $0.597(0.062)$ \\
U. Columbia chinook (S-F) & Wanapum Dam & $0.794(0.015)$ & $0.891(0.043)$ & $0.707(0.037)$ & $0.820(0.097)$ & $0.582(0.061)$ \\
U. Columbia chinook (S-F) & Priest Rapids Dam & $0.847(0.014)$ & $0.891(0.043)$ & $0.755(0.039)$ & $0.820(0.097)$ & $0.621(0.064)$ \\
Yakima R. chinook & Several Locations & NA* & $0.880(0.030)$ & NA* & NA & NA* \\
Snake R. steelhead & Lower Granite Dam & $0.597(0.013)$ & $0.879(0.032)$ & $0.525(0.022)$ & $0.630(0.066)$ & $0.309(0.011)$ \\
\hline
\end{tabular}

* Fish were released at numerous locations in the Yakima River basin. Single point of release to McNary survival estimate not possible. 
Table 43. Percent of PIT-tagged smolts (wild and hatchery combined) detected at Lower Monumental Dam later detected on McNary pool bird colonies, 1998-2003.

\begin{tabular}{lcc}
\hline Year & Yearling chinook salmon & Steelhead \\
\hline 1998 & 0.49 & 4.20 \\
1999 & 0.84 & 4.51 \\
2000 & 0.98 & 3.66 \\
2001 & 5.59 & 21.06 \\
2002 & 1.19 & 10.09 \\
$2003 *$ & 1.06 & 3.71 \\
\hline
\end{tabular}

* Only the Crescent Island Caspian tern colony sampled. 


\section{FIGURES}




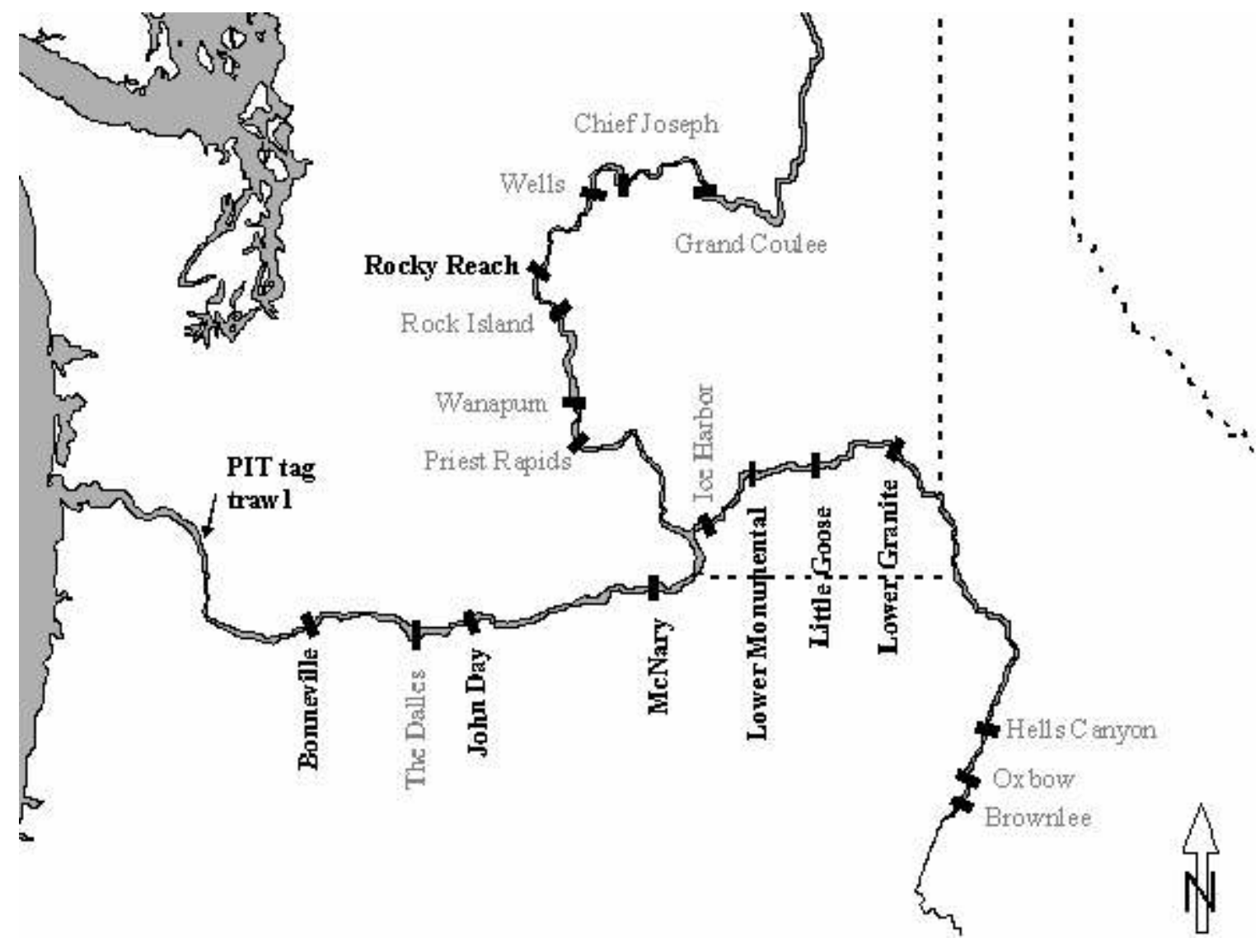

Figure 1. Study area showing sites with PIT-tag detection facilities (names in black), including dams and the PIT-tag trawl in the Columbia River estuary. Dams with names in gray do not have detection facilities. 

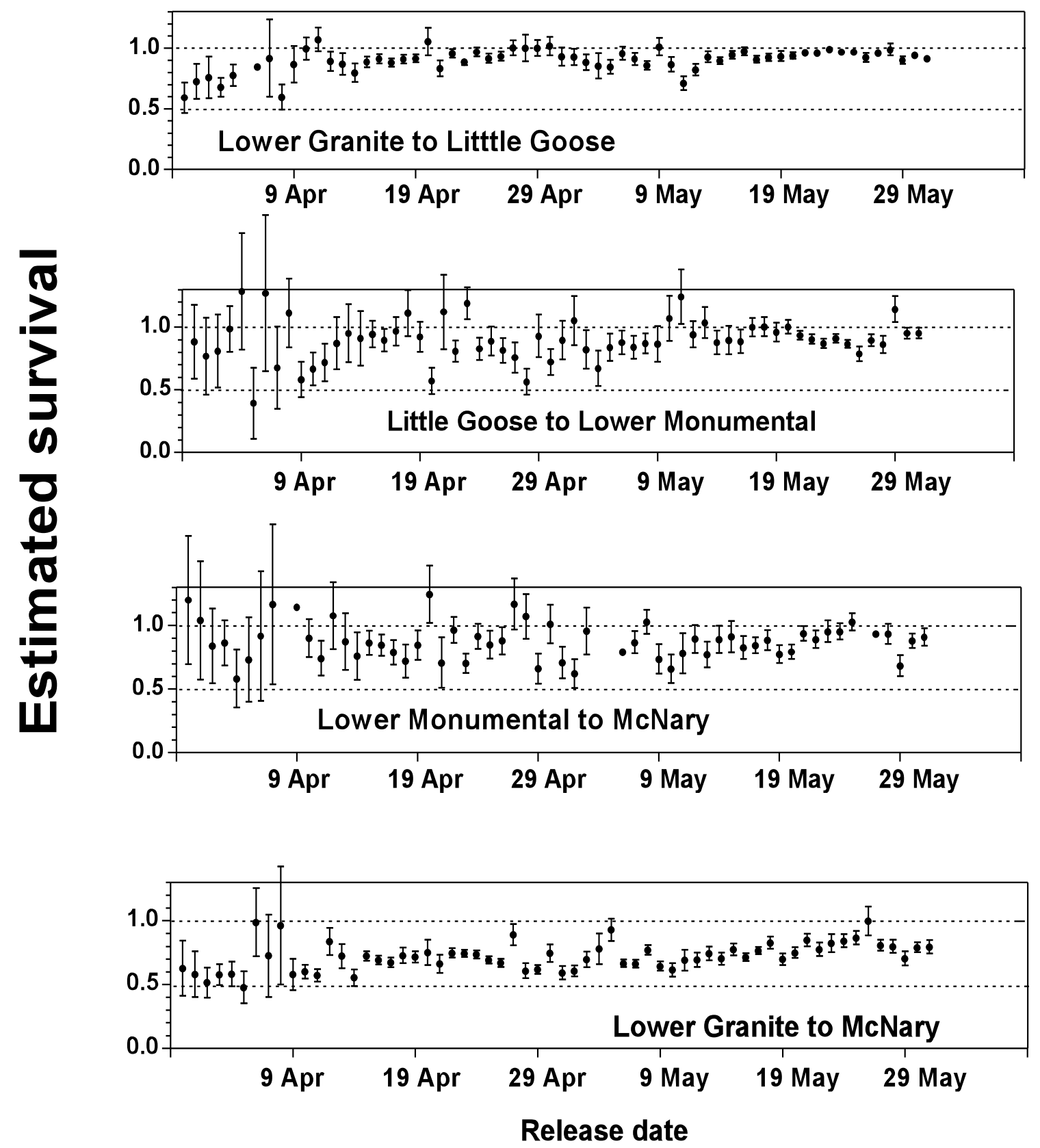

Figure 2. Estimated survival through various reaches vs. release date at Lower Granite Dam for daily release groups of Snake River yearling chinook salmon, 2003. Bars extend one standard error above and below point estimates. 


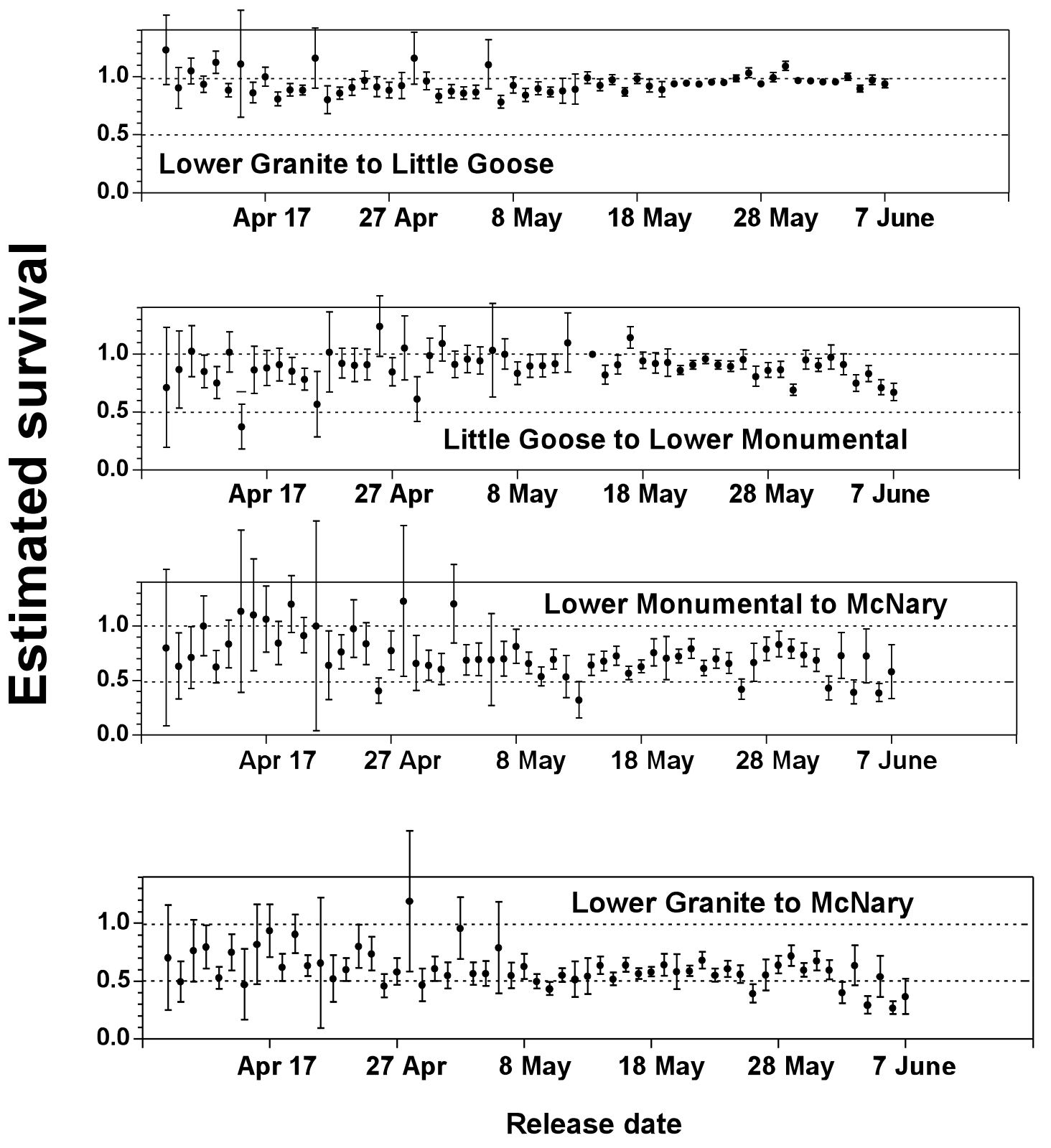

Figure 3. Estimated survival through various reaches versus release date at Lower Granite Dam for daily release groups of Snake River steelhead, 2003. Bars extend one standard error above and below point estimates. 


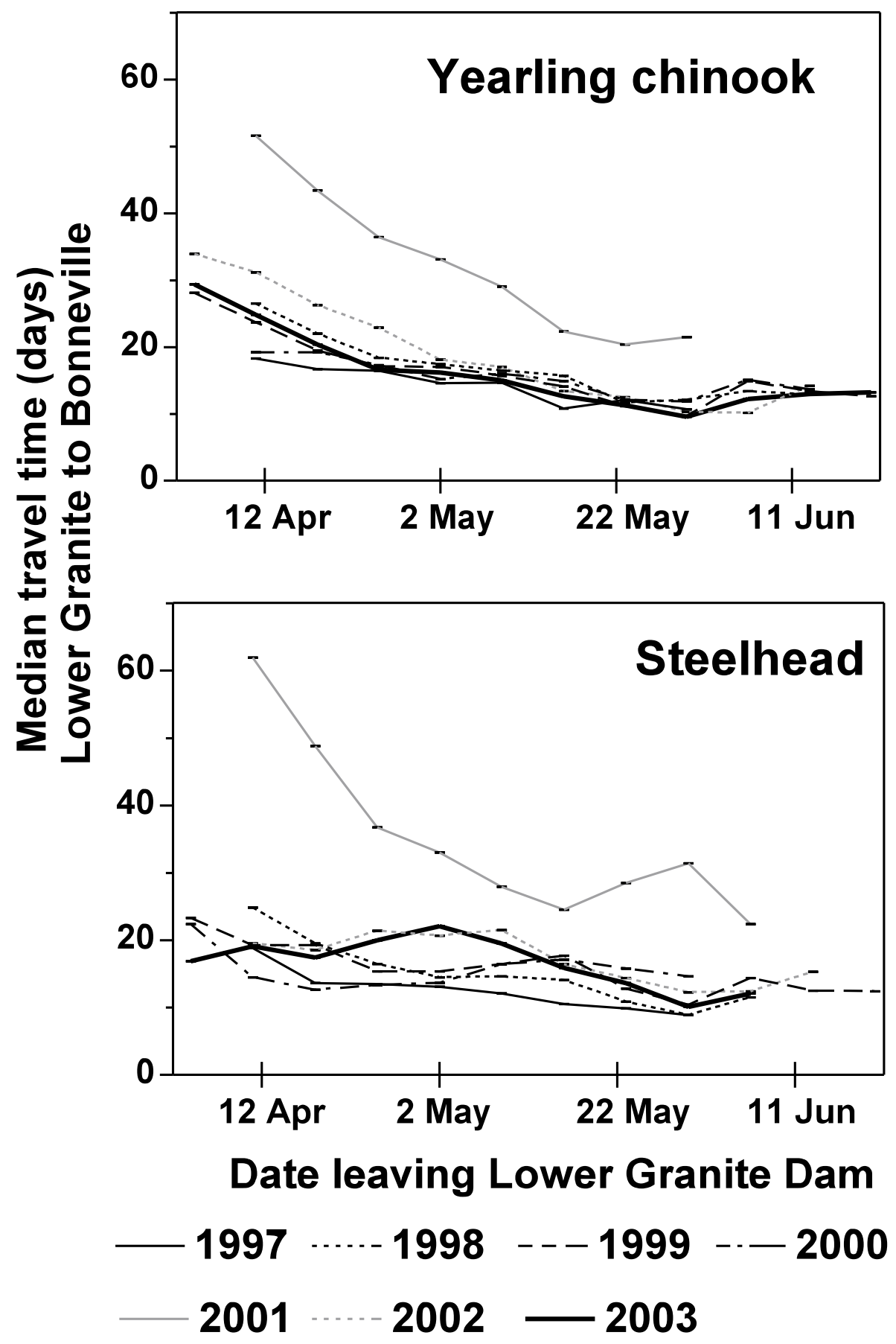

Figure 4. Median travel time (days) from Lower Granite Dam to Bonneville Dam for weekly release groups of Snake River yearling chinook salmon and steelhead from Lower Granite Dam, 1997-2003. 


\section{Chinook salmon 2003}

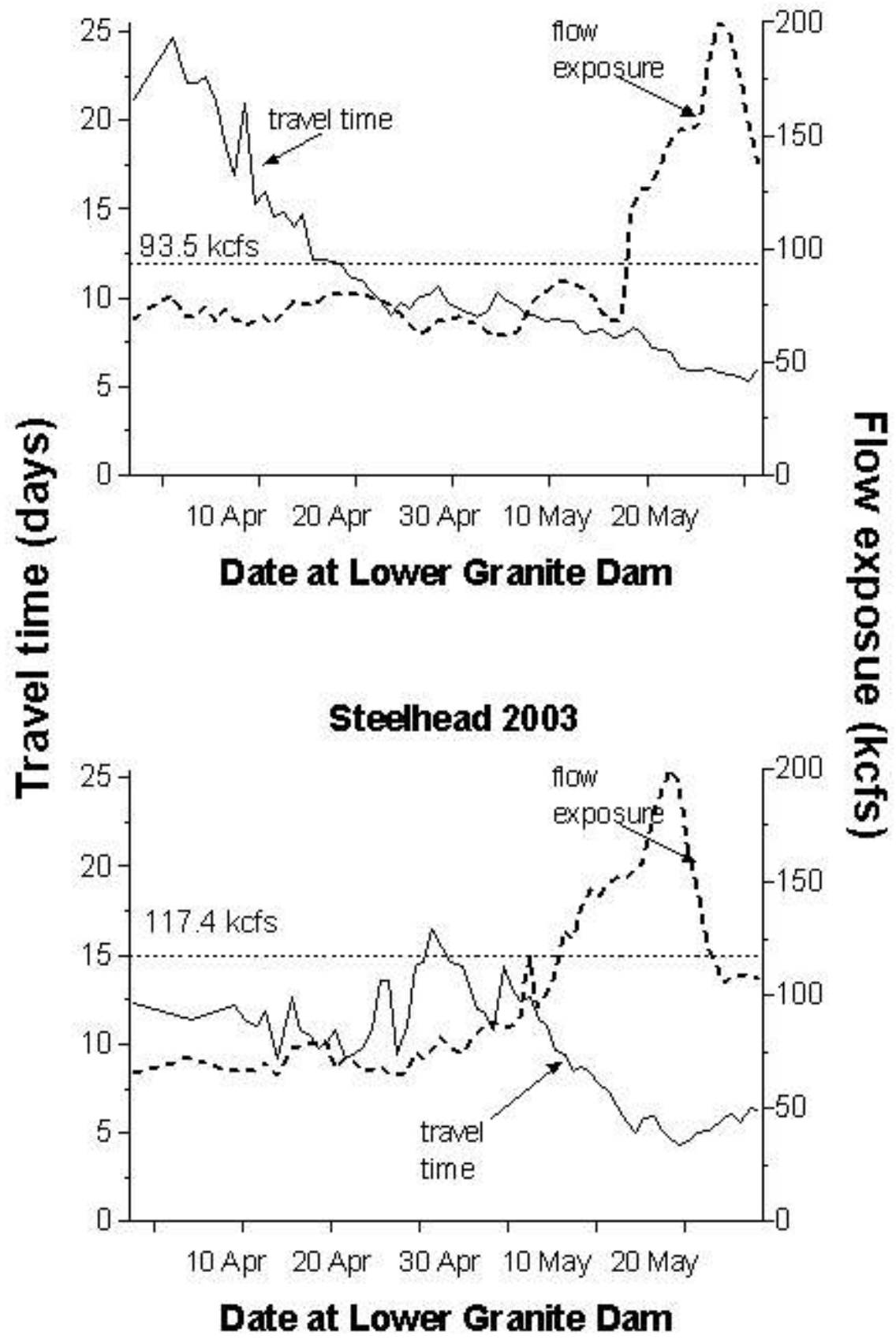

Figure 5. Travel time (days) for yearling chinook salmon and steelhead from Lower Granite Dam to McNary Dam and index of flow exposure at Lower Granite Dam (kcfs) for daily groups of PIT-tagged fish during 2003. Dashed horizontal lines represent the annual average flow exposure index, weighted by the number of PIT-tagged fish in each group. 


\section{Hatchery yearling chinook salmon (1993-2003)}

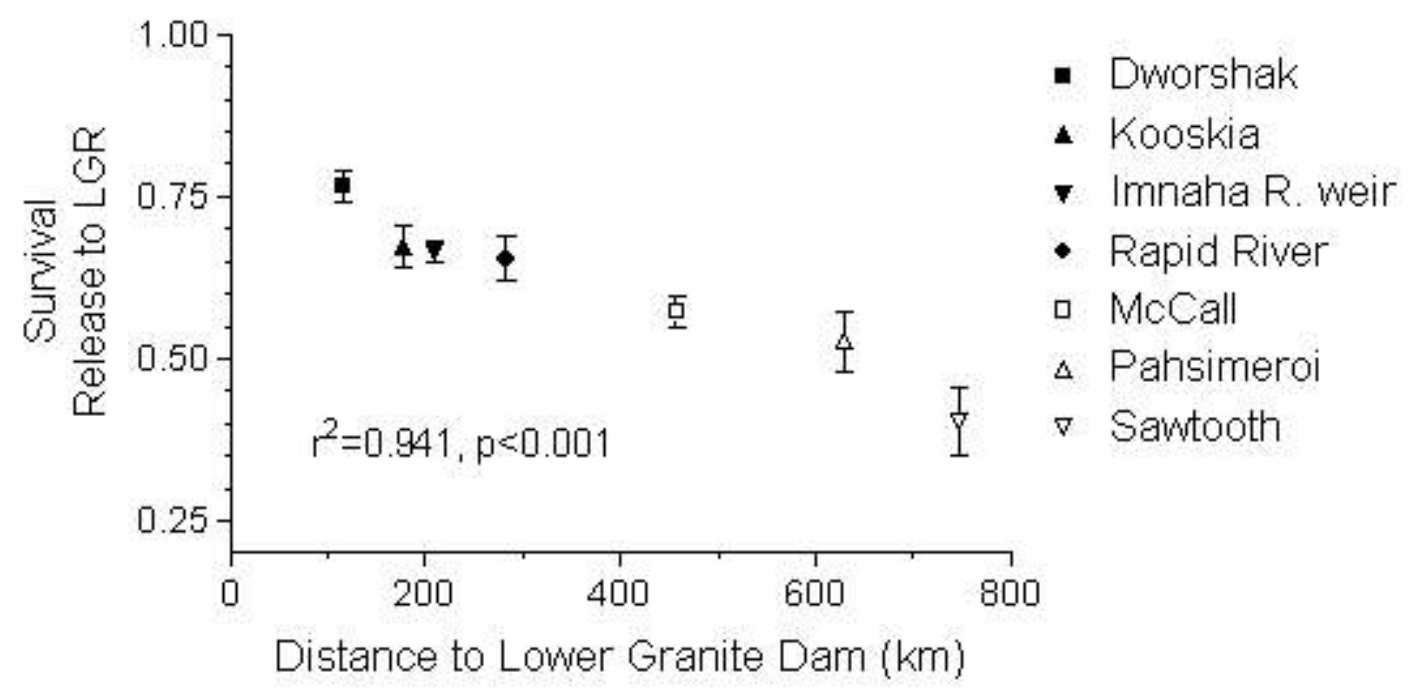

Figure 6. Estimated survival with standard errors from release at Snake River Basin hatcheries to Lower Granite Dam tailrace, 1993-2003 vs distance $(\mathrm{km})$ to Lower Granite Dam. The correlation between survival and migration distance is also shown. 
Yearling Chinook Salmon

Steelhead

Lower Granite to Little Goose
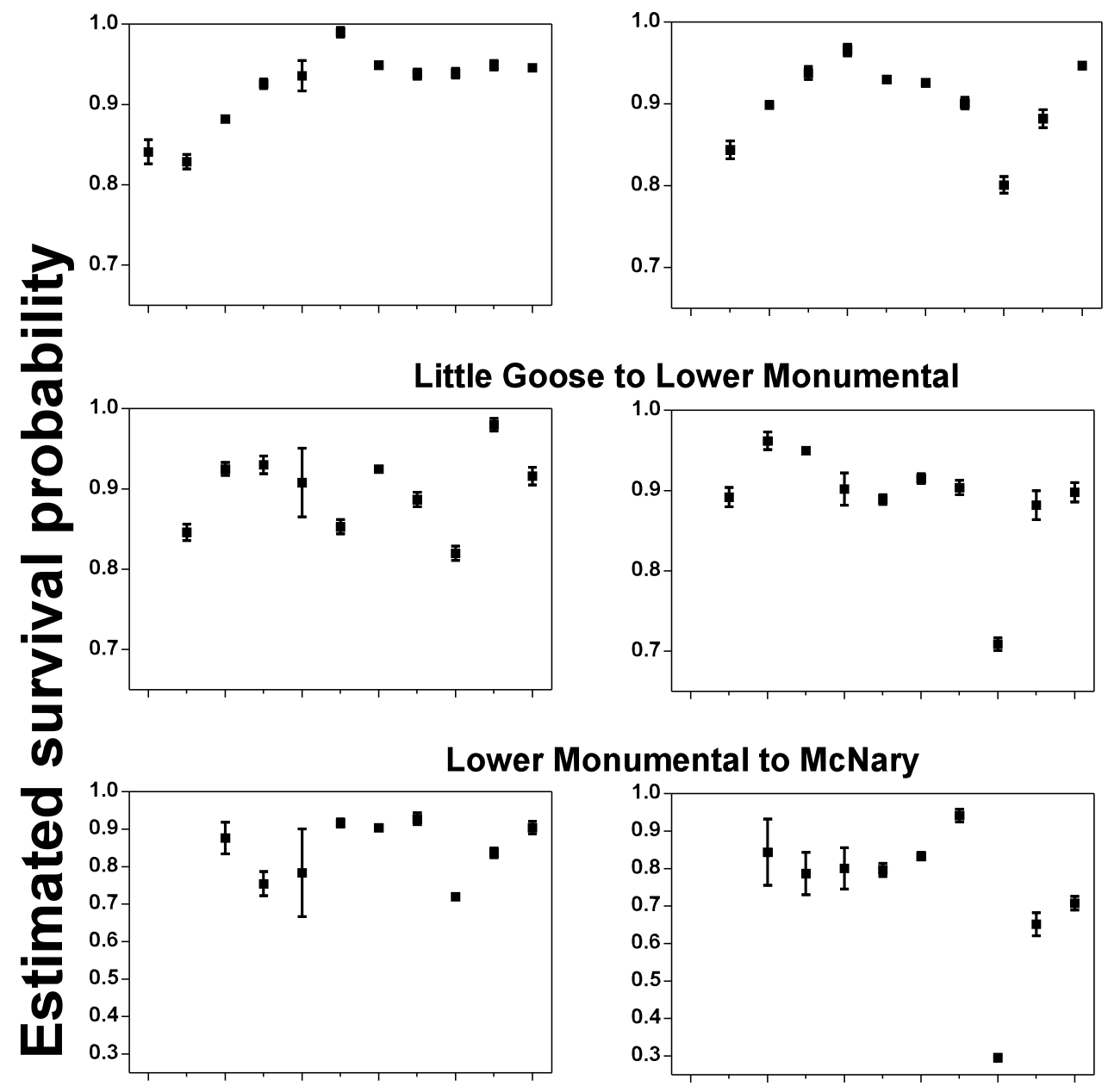

Lower Granite to McNary
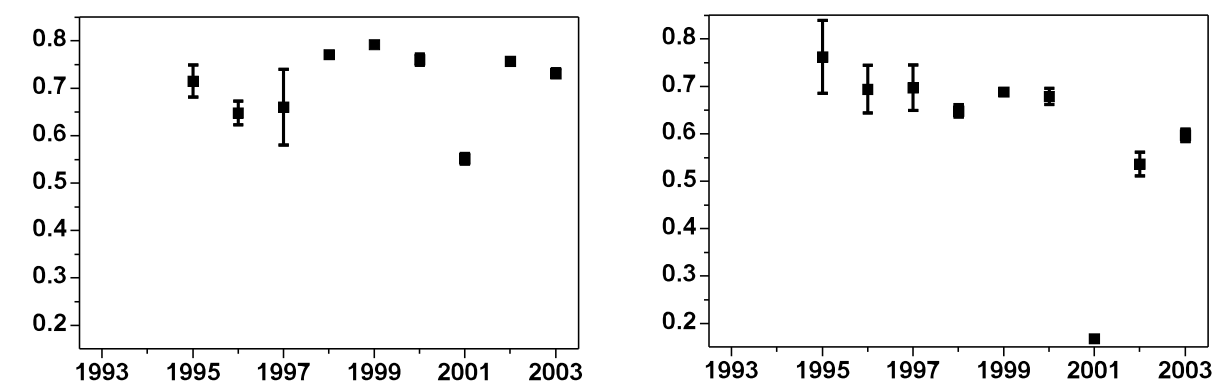

Figure 7. Annual average survival estimates for PIT-tagged yearling chinook salmon and steelhead through Snake River reaches, 2003. Estimates are from tailrace to tailrace with standard errors. 
Yearling Chinook Salmon

\section{Steelhead}

McNary to John Day
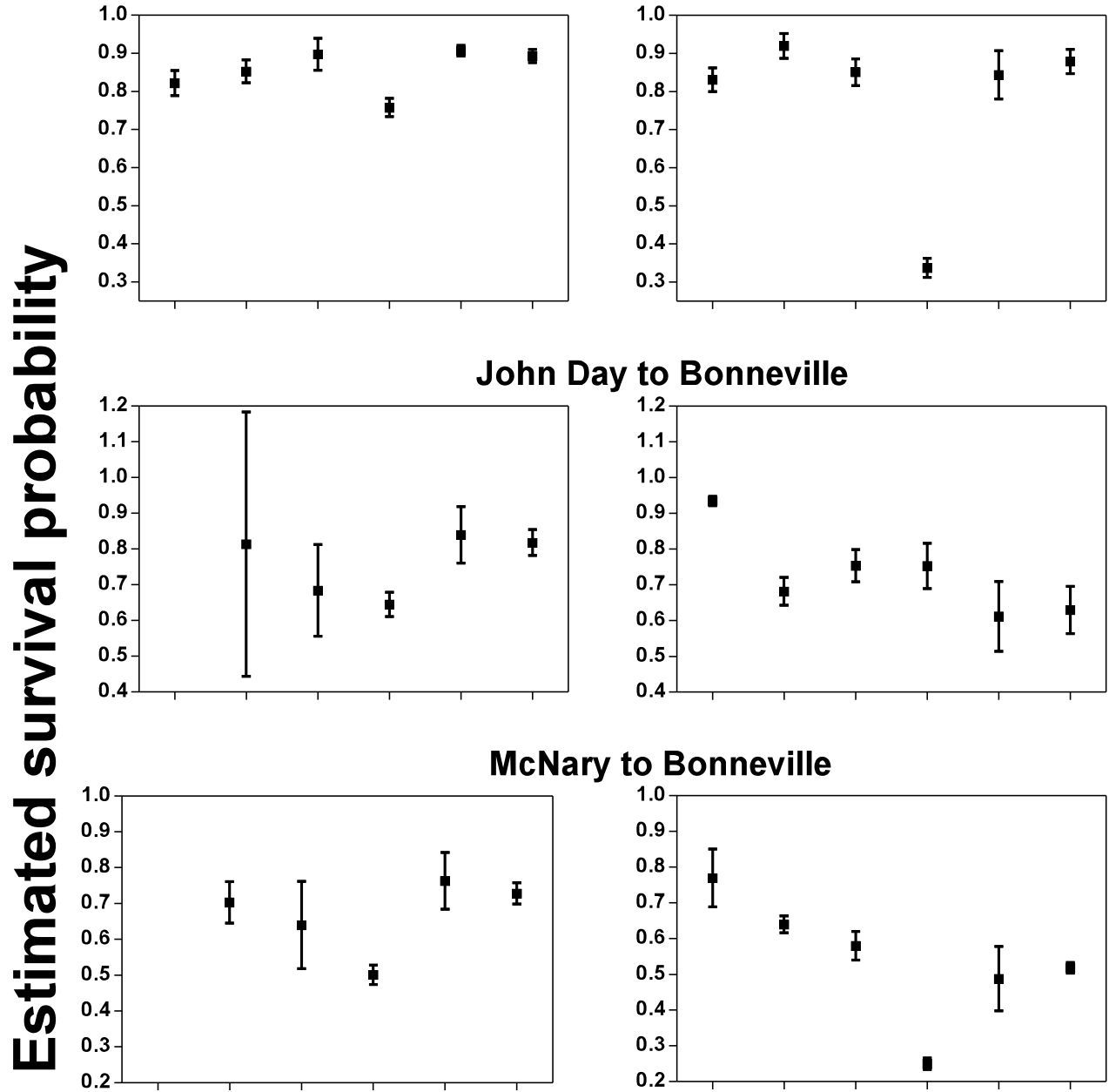

\section{Lower Granite to Bonneville}
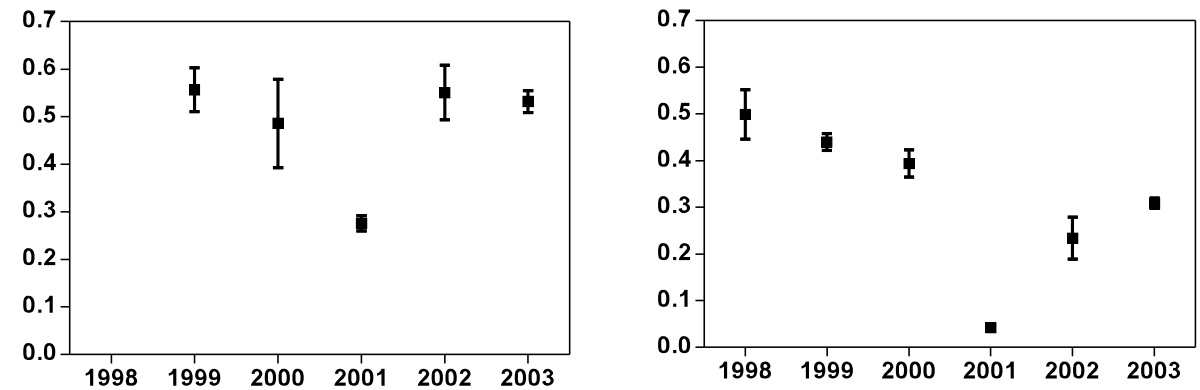

Figure 8. Annual average survival estimates for PIT-tagged Snake River yearling chinook salmon and steelhead through Columbia River reaches and from Lower Granite Dam to Bonneville Dam, 2003. Estimates are from tailrace to tailrace with standard errors. 


\section{Chinook salmon 2001}
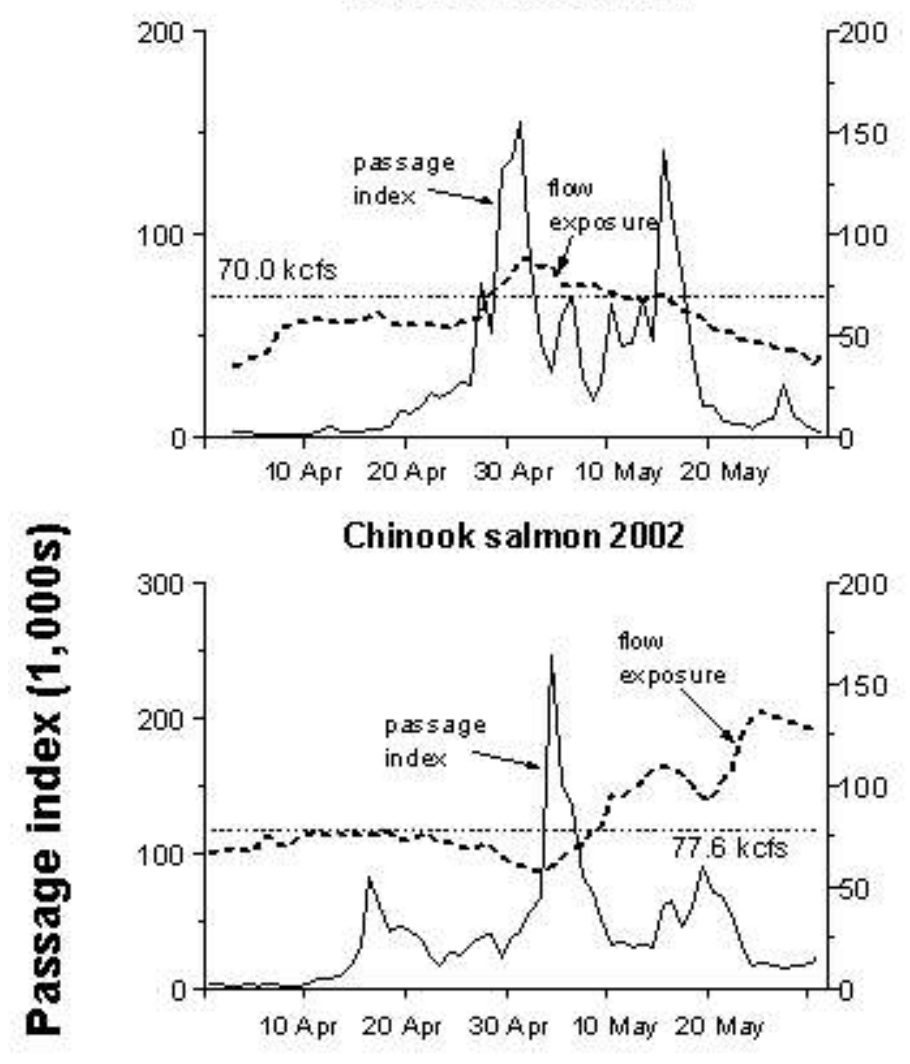

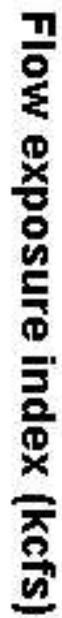

Chinook salmon 2003

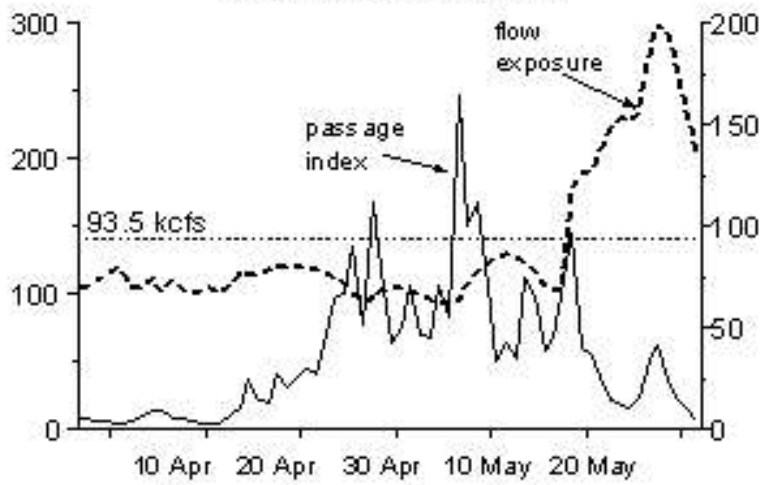

Date at Lower Granite Dam

Figure 9. Passage index for yearling chinook salmon at Lower Granite Dam and index of flow exposure at Lower Granite Dam (kcfs) for daily groups of PIT-tagged yearling chinook salmon from Lower Granite Dam during 2001, 2002, and 2003. Dashed horizontal lines represent the annual average flow exposure index, weighted by the number of PIT-tagged fish in each group. 


\section{Steelhead 2001}

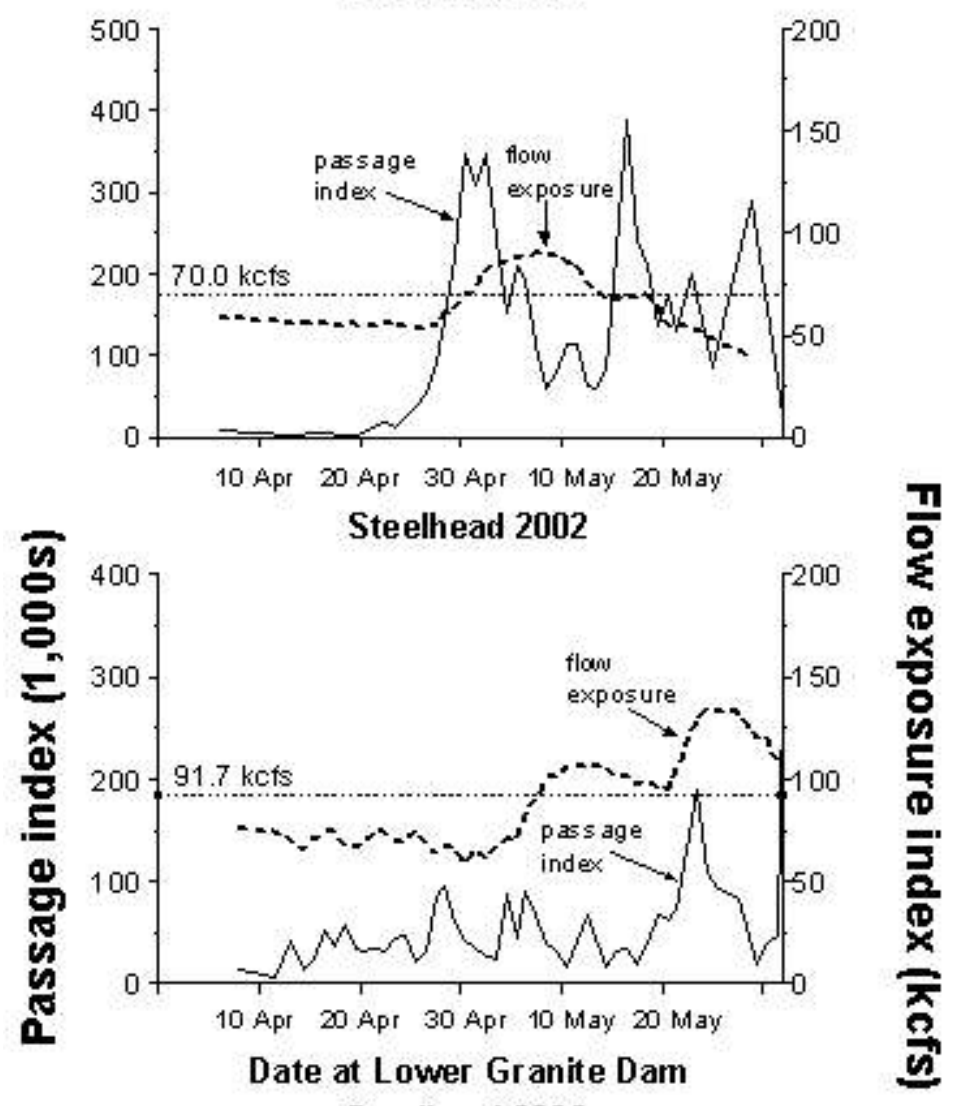

Steelhead 2003

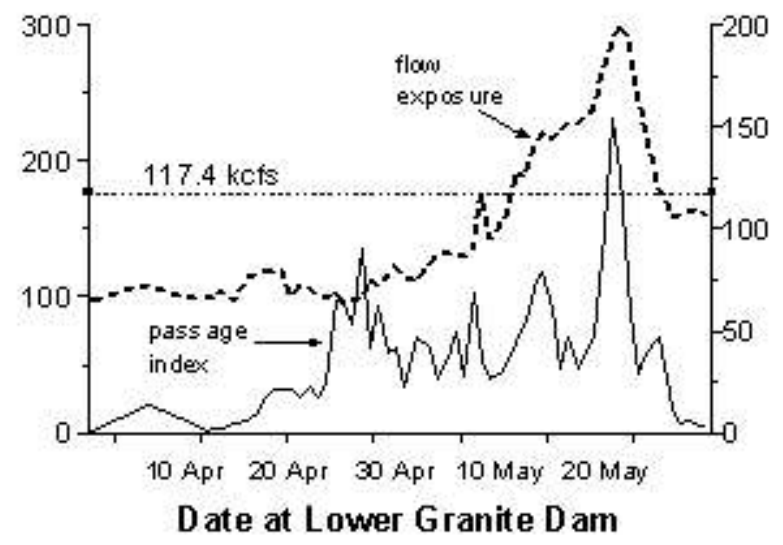

Figure 10. Passage index for steelhead at Lower Granite Dam and index of flow exposure at Lower Granite Dam (kcfs) for daily groups of PIT-tagged steelhead from Lower Granite Dam during 2001, 2002, and 2003. Dashed horizontal lines represent the annual average flow exposure index, weighted by the number of PIT-tagged fish in each group. 


\section{APPENDIX: Tests of Model Assumptions}

\section{Background}

Using the Cormack-Jolly-Seber (CJS), or Single-Release (SR) Model, the passage of a single PIT-tagged salmonid through the hydropower system is modeled as a sequence of events. Examples of such events are survival from the tailrace of Lower Granite Dam to the tailrace of Little Goose Dam, and detection at Little Goose Dam. Each event has an associated probability of occurrence (technically, these probabilities are "conditional", as they are defined only if a certain condition is met, for example "probability of detection at Little Goose Dam given that the fish survived to Little Goose Dam").

The detection history, then, is the record of the outcomes of the series of events. (The detection history is an imperfect record of outcomes; if the history ends with one or more "zeroes," we cannot distinguish mortality from survival without detection). The SR Model represents detection history data for a group of tagged fish as a multinomial distribution; each multinomial cell probability (detection history probability) is a function of the underlying survival and detection event probabilities. Three key assumptions lead to the multinomial cell probabilities used in the SR Model:

A1) Fish in a single group of tagged fish have common event probabilities (each conditional detection or survival probability is common to all fish in the group).

A2) Event probabilities for each individual fish are independent from those for all other fish.

A3) Each event probability for an individual fish is conditionally independent from all other probabilities.

For a migrating PIT-tagged fish, assumption A3 implies that detection at any particular dam does not affect (or give information regarding) probabilities of subsequent

events. For the group as a whole, this means that detected and nondetected fish at a given dam have the same probability of survival in downstream reaches, and have the same conditional probability of detection at downstream dams. 


\section{Methods}

We used the methods presented by Burnham et al. (1997; pp 71-77) to assess the goodness-of-fit of the SR model to observed detection history data. In these tests, we compiled a series of contingency tables from detection history data for each group of tagged fish, and used $\mathrm{c}^{2}$ tests to identify systematic deviations from what was expected if the assumptions were met. We applied the tests to weekly groups of yearling chinook salmon and steelhead (hatchery and wild combined) leaving Lower Granite and McNary dams (Snake River-origin fish only) in 2003 (i.e., the fish used for survival estimates reported in Tables 1, 2, 10, and 11).

If goodness-of-fit tests for a series of release groups resulted in more significant tests than expected by chance, we compared observed and expected tables to determine the nature of the violation. While consistent patterns of violations in the assumption testing do not unequivocally pinpoint the cause of the violation, they can be suggestive, and some hypothesized causes may be ruled out.

Potential causes of assumption violations include inherent differences between individuals in survival or detectability (e.g., propensity to be guided by bypass screens); differential mortality between the passage route that is monitored for PIT tags (juvenile collection system) and those that are not (spillways and turbines); behavioral responses to bypass and detection; and differences in passage timing for detected and non-detected fish if such differences result in exposure to different conditions downstream. Using detection information, inherent differences and behavioral responses are virtually indistinguishable. Conceptually, we make the distinction that inherent traits are those that characterized the fish before any hydrosystem experience, while behavioral responses occur as a result of particular hydrosystem experiences. For example, developing a preference for a particular passage route is a behavioral response, while size-related differences in passage-route selection are inherent. Of course, response to passage experience may also depend on inherent characteristics.

To describe each test we conducted, we follow the nomenclature of Burnham et al. (1987). For release groups from Lower Granite Dam, we analyzed 4-digit detection histories indicating status at Little Goose, Lower Monumental, and McNary Dams, and the final digit for detection anywhere below McNary Dam. 
The first test for Lower Granite Dam groups was "Test 2.C2," which is based on the contingency table:

\begin{tabular}{l|c|c|c|}
\cline { 2 - 4 } \multirow{2}{*}{$\begin{array}{l}\text { Test } 2 . \mathrm{C} 2 \\
\mathrm{df}=2\end{array}$} & \multicolumn{2}{|c|}{ First site detected below LGO } \\
\cline { 2 - 4 } & LMN & $\mathrm{MCN}$ & JDA or below \\
\hline Not detected at LGO & $n_{11}$ & $n_{12}$ & $n_{13}$ \\
\hline Detected at LGO & $n_{21}$ & $n_{22}$ & $n_{23}$ \\
\hline
\end{tabular}

In this table, all fish that were detected somewhere below Little Goose Dam are cross-classified according to their history at Little Goose Dam and according to their first detection site below Little Goose Dam (e.g., $n_{11}$ is the number of fish not detected at Little Goose Dam that were first detected downstream at Lower Monumental Dam). If all assumptions were met, the counts for fish detected at LGO should be in constant proportion to those for fish not detected (i.e., $n_{11} / n_{21}, n_{12} / n_{22}$, and $n_{13} / n_{23}$ should be equal).

Because this table counts only fish detected below LGO (i.e., all fish survived LGO passage), differential direct mortality for fish detected and not detected at LGO will not cause violations of Test 2.C2 by itself. However, differential indirect mortality related to LGO passage could cause violations if differences are not expressed until fish are below LMO. Behavioral response to guidance at LGO could cause violations of Test 2.C2: if fish detected at LGO become more likely to be detected downstream, then they will tend to have more first downstream detections at LMO. If detected fish at LGO become less likely to be detected downstream, then they will have fewer first detections at LMO. Inherent differences among fish could also cause violations of Test 2.C2, and would be difficult to distinguish from behavioral responses.

The second test for Lower Granite Dam groups was Test 2.C3, based on the contingency table:

\begin{tabular}{l|c|c|}
\cline { 2 - 3 } \multirow{2}{*}{$\begin{array}{l}\text { Test 2.C3 } \\
\mathrm{df}=1\end{array}$} & First site detected below LMN \\
\cline { 2 - 3 } Not detected at LMN & $n_{11}$ & JDA or below \\
\hline Detected at LMN & $n_{21}$ & $n_{12}$ \\
\hline
\end{tabular}


This table and corresponding implications are similar to Test 2.C2. All fish that were detected somewhere below LMN are cross-classified according to their history at LMN and according to their first detection site below LMN. If the respective counts for fish first detected at MCN are not in the same proportion as those first detected at JDA or below, it could indicate behavioral response to detection at LMN, inherent differences in detectability (i.e., guidability) among tagged fish in the group, or long-term differential mortality caused by different passage routes at LMN.

The next series of tests for Lower Granite Dam groups is called Test 3. The first in the series is called Test 3.SR3, based on the contingency table:

\begin{tabular}{l|c|c|}
\cline { 2 - 3 } \multirow{2}{*}{ Test 3.SR3 } & \multicolumn{2}{|c|}{ Detected again at MCN or below? } \\
\cline { 2 - 3 } $\mathrm{df}=1$ & YES & NO \\
\hline Detected at LMN, not detected at LGO & $n_{11}$ & $n_{12}$ \\
\hline Detected at LMN, detected at LGO & $n_{21}$ & $n_{22}$ \\
\hline
\end{tabular}

In this table, all fish detected at LMN are cross-classified according to their status at LGO and whether or not they were detected again downstream from LMN. As with the Test 2 series, differential mortality in different passage routes at LGO will not be detected by this test if all the mortality is expressed before the fish arrive at LMN. Differences in mortality expressed below MCN could cause violations, however, as could behavioral responses (possibly somewhat harder to detect because of the conditioning on detection at LMN) or inherent differences in detectability or survival between fish detected at LGO and those not detected there.

The second test in the Test 3 series is Test $3 . \mathrm{Sm} 3$, based on the contingency table:

\begin{tabular}{l|c|c|}
\cline { 2 - 3 } \multirow{2}{*}{ Test 3.Sm3 } & \multicolumn{2}{|c|}{ Site first detected below LMN } \\
\cline { 2 - 3 } $\mathrm{df}=1$ & $\mathrm{MCN}$ & JDA \\
\hline Detected at LMN, not detected at LGO & $n_{11}$ & $n_{12}$ \\
\hline Detected at LMN, detected at LGO & $n_{21}$ & $n_{22}$ \\
\hline
\end{tabular}


This test is sensitive to the same sorts of differences as Test 3.SR3, but tends to have somewhat less power. Because the table classifies only fish detected somewhere below $\mathrm{LMN}$, it is not sensitive to differences in survival between LMN and MCN.

The final test for Lower Granite Dam groups is Test 3.SR4, based on the contingency table:

Test 3.SR4

$\mathrm{df}=1$

Detected at MCN, not detected previously

Detected at MCN, also detected previously

\begin{tabular}{|c|c|}
\hline \multicolumn{2}{|c|}{ Detected at JDA or below? } \\
\hline Yes & No \\
\hline$n_{11}$ & $n_{12}$ \\
\hline$n_{21}$ & $n_{22}$ \\
\hline
\end{tabular}

This table classifies all fish detected at MCN according to whether they had been detected at least once at LGO and LMN and whether they were detected again below MCN. A significant test indicates that some below-MCN parameter(s) differ between fish detected above $\mathrm{MCN}$ and those not detected. The cause of such an assumption violation could be differences in indirect survival associated with detection at LGO and/or LMN (mortality expressed between MCN and the estuary PIT-trawl), inherent differences in survival or detection probabilities, or behavioral responses.

We did not include any contingency table tests when any of the expected cells of the table were less than 1.0, as the test statistic does not sufficiently approximate the asymptotic $\mathrm{c}^{2}$ distribution in these cases. (For Test 2.C2, when the expected values in the "LMN" and "MCN" columns were all greater than 1.0, but one or two of the expected values in the "JDA or below" column were less than 1.0, we collapsed the "MCN" and "JDA or below" and calculated a one-degree-of-freedom test of the resulting 2-by-2 table). We combined the two test statistics in the Test 2 series and the three in the Test 3 series and then all tests together in a single overall $\mathrm{c}^{2}$ test statistic.

For release groups from McNary Dam, we analyzed 3-digit detection histories indicating status at John Day Dam, Bonneville Dam, and the estuary PIT-trawl. 
Only two tests are possible for 3-digit detection histories. The first of these was Test 2.C2, based on the contingency table:

\begin{tabular}{l|c|c|}
\cline { 2 - 3 } Test 2.C2 & \multicolumn{2}{|c|}{ First site detected below JDA } \\
\cline { 2 - 3 } $\mathrm{df}=1$ & BON & Trawl \\
\hline Not detected at JDA & $n_{11}$ & $n_{12}$ \\
\hline Detected at JDA & $n_{21}$ & $n_{22}$ \\
\hline
\end{tabular}

and the second is Test 2.SR3, based on the contingency table:

\begin{tabular}{l|c|c|}
\cline { 2 - 3 } Test 3.SR3 & \multicolumn{2}{|c|}{ Detected at Trawl } \\
\cline { 2 - 3 } df $=1$ & Yes & No \\
\hline Detected at BON, not detected at JDA & $n_{11}$ & $n_{12}$ \\
\hline Detected at BON, detected at JDA & $n_{21}$ & $n_{22}$ \\
\hline
\end{tabular}

These tests are analogous to Tests 2.C3 and 3.SR4, respectively, for the Lower Granite Dam release groups. Potential causes of violations of the tests for McNary Dam groups are the same as those for Lower Granite Dam groups. 


\section{Results}

For weekly Lower Granite Dam release groups in 2003 there were more significant $(\alpha=0.05)$ tests of goodness of fit than expected by chance alone for yearling chinook salmon, but not for steelhead, except for Test 2.C3 (Appendix Table 1). There were 13 weekly groups of yearling chinook salmon. For these, the overall sum of the $\mathrm{c}^{2}$ test statistics was significant 4 times. For 10 steelhead groups, the overall test was significant twice. Counting all individual tests (e.g., 2.C2, 3.SR3), 10 tests of 63 (16\%) were significant for yearling chinook salmon and 4 of $48(8 \%)$ were significant for steelhead (Appendix Tables 1-3). The most frequently significant tests (each with 3 significant tests of 13) for yearling chinook salmon were 3.SR3 and 3.SR4.

We diagnosed the patterns in the contingency tables that led to significant tests and results were similar to the those we reported in 1999 through 2001 (Zabel et al. 2002): in 7 of the 10 significant cases for yearling chinook salmon and in 3 of the 4 cases for steelhead, there was evidence that fish previously detected were more likely to be detected again at downstream dams.

Significant contingency table test results were far less common for weekly groups from McNary Dam (Appendix Tables 4 through 6).

\section{Discussion}

We believe that inherent differences in detectability (guidability) of fish within a release group are the most likely cause of the patterns we observed in the contingency table tests in 2003, as in 1999 through 2001. Zabel et al. (2002) provided evidence of inherent differences related to length of fish at tagging, and similar observations were made in 2003 data. Fish size probably does not explain all inherent differences, but it appears to explain some. The relationship between length at tagging and detection probability at Little Goose Dam, the first dam encountered after release by fish in these data sets (all fish in the data set were detected at Lower Granite Dam; Little Goose Dam is the first encountered after leaving LGR), suggests that the heterogeneity is inherent, and not a behavioral response.

As in 1999 through 2001 (Zabel et al. 2002), results in 2003 lead us to conclude, as did Burnham et al. (1987), that a reasonable amount of heterogeneity in the survival and detection process did not seriously affect the performance of estimators of survival. 
Appendix Table 1. Number of tests of goodness of fit to the Single Release Model conducted for weekly release groups of yearling chinook salmon and steelhead (hatchery and wild combined) from Lower Granite Dam, and number of significant $(\alpha=0.05)$ test results, 2003.

\begin{tabular}{|c|c|c|c|c|c|c|c|c|c|c|c|c|c|c|c|c|}
\hline \multirow[b]{2}{*}{ Species } & \multicolumn{2}{|c|}{ Test 2.C2 } & \multicolumn{2}{|c|}{ Test 2.C3 } & \multicolumn{2}{|c|}{ Test 3.SR3 } & \multicolumn{2}{|c|}{$\underline{\text { Test } 3 . \mathrm{Sm} 3}$} & \multicolumn{2}{|c|}{ Test 3.SR4 } & \multicolumn{2}{|c|}{ Test 2 sum } & \multicolumn{2}{|c|}{ Test 3 sum } & \multicolumn{2}{|c|}{ Test $2+3$} \\
\hline & No. & sig. & No. & sig. & No. & sig. & No. & sig. & No. & sig. & No. & sig. & No. & sig. & No. & sig. \\
\hline Chinook & 13 & 1 & 13 & 2 & 13 & 3 & 11 & 1 & 13 & 3 & 13 & 2 & 13 & 4 & 13 & 4 \\
\hline Steelhead & 10 & 0 & 9 & 3 & 10 & 0 & 9 & 0 & 10 & 0 & 10 & 3 & 10 & 1 & 10 & 2 \\
\hline Total & 23 & 1 & 22 & 5 & 23 & 3 & 20 & 1 & 23 & 3 & 23 & 5 & 23 & 5 & 23 & 6 \\
\hline
\end{tabular}


Appendix Table 2. Results of tests of goodness of fit to the Single Release Model for release groups of yearling chinook salmon (hatchery and wild) from Lower Granite to McNary Dam in 2003.

\begin{tabular}{lcccccccc}
\hline & \multicolumn{2}{c}{ Overall } & \multicolumn{2}{c}{ Test 2 } & \multicolumn{2}{c}{ Test 2.C2 } & \multicolumn{2}{c}{ Test 2.C3 } \\
Release & $\chi^{2}$ & P value & $\chi^{2}$ & P value & $\chi^{2}$ & P value & $\chi^{2}$ & P value \\
\hline 30 Mar-05 Apr & 15.43 & 0.02 & 1.39 & 0.71 & 1.26 & 0.53 & 0.12 & 0.73 \\
06 Apr-12 Apr & 6.84 & 0.34 & 3.22 & 0.36 & 2.83 & 0.24 & 0.39 & 0.53 \\
13 Apr-19 Apr & 5.47 & 0.49 & 1.34 & 0.72 & 1.25 & 0.54 & 0.10 & 0.76 \\
20 Apr-26 Apr & 10.24 & 0.12 & 0.64 & 0.89 & 0.37 & 0.83 & 0.27 & 0.60 \\
27 Apr-03 May & 1.76 & 0.94 & 0.15 & 0.99 & 0.14 & 0.93 & 0.01 & 0.93 \\
04 May-10 May & 4.74 & 0.58 & 3.10 & 0.38 & 2.98 & 0.23 & 0.12 & 0.73 \\
11 May-17 May & 15.47 & 0.02 & 2.95 & 0.40 & 2.74 & 0.25 & 0.21 & 0.65 \\
18 May-24 May & 19.41 & 0.00 & 17.03 & 0.00 & 10.48 & 0.01 & 6.54 & 0.01 \\
25 May-31 May & 17.75 & 0.01 & 11.58 & 0.01 & 4.63 & 0.10 & 6.95 & 0.01 \\
01 Jun-07 Jun & 13.25 & 0.04 & 1.91 & 0.59 & 0.47 & 0.79 & 1.44 & 0.23 \\
08 Jun-14 Jun & 5.03 & 0.54 & 2.05 & 0.56 & 1.55 & 0.46 & 0.50 & 0.48 \\
15 Jun-21 Jun & 0.93 & 0.92 & 0.58 & 0.75 & 0.58 & 0.45 & 0.00 & 0.98 \\
22 Jun-28 Jun & 3.92 & 0.27 & 2.04 & 0.15 & 2.04 & 0.15 & NA & NA \\
\hline Total (d.f.) & $120.2(73)$ & $<0.001$ & $47.97(36)$ & 0.09 & $31.32(24)$ & 0.14 & $16.64(12)$ & 0.16 \\
\hline
\end{tabular}


Appendix Table 2. Continued.

\begin{tabular}{lcccccccc}
\hline & \multicolumn{2}{c}{ Test 3 } & \multicolumn{2}{c}{ Test 3.SR3 } & \multicolumn{2}{c}{ Test 3.Sm3 } & \multicolumn{2}{c}{ Test 3.SR4 } \\
Release & $\chi^{2}$ & P value & $\chi^{2}$ & P value & $\chi^{2}$ & P value & $\chi^{2}$ & P value \\
\hline 30 Mar-05 Apr & 14.05 & 0.00 & 4.42 & 0.04 & 4.79 & 0.03 & 4.84 & 0.03 \\
06 Apr-12 Apr & 3.62 & 0.31 & 2.84 & 0.09 & 0.52 & 0.47 & 0.26 & 0.61 \\
13 Apr-19 Apr & 4.13 & 0.25 & 0.38 & 0.54 & 2.93 & 0.09 & 0.82 & 0.37 \\
20 Apr-26 Apr & 9.60 & 0.02 & 5.15 & 0.02 & 1.39 & 0.24 & 3.06 & 0.08 \\
27 Apr-03 May & 1.61 & 0.66 & 0.98 & 0.32 & 0.44 & 0.51 & 0.19 & 0.66 \\
04 May-10 May & 1.64 & 0.65 & 1.10 & 0.29 & 0.16 & 0.69 & 0.38 & 0.54 \\
11 May-17 May & 12.52 & 0.01 & 0.09 & 0.76 & 0.73 & 0.39 & 11.70 & 0.001 \\
18 May-24 May & 2.38 & 0.50 & 1.15 & 0.28 & 0.20 & 0.65 & 1.03 & 0.31 \\
25 May-31 May & 6.17 & 0.10 & 0.77 & 0.38 & 1.28 & 0.26 & 4.12 & 0.04 \\
01 Jun-07 Jun & 11.35 & 0.01 & 9.60 & 0.00 & 0.02 & 0.89 & 1.73 & 0.19 \\
08 Jun-14 Jun & 2.98 & 0.40 & 1.26 & 0.26 & 0.55 & 0.46 & 1.17 & 0.28 \\
15 Jun-21 Jun & 0.35 & 0.84 & 0.04 & 0.85 & NA & NA & 0.31 & 0.58 \\
22 Jun-28 Jun & 1.88 & 0.39 & 1.24 & 0.27 & NA & NA & 0.64 & 0.42 \\
\hline Total (d.f.) & $72.27(37)$ & $<0.001$ & $29.02(13)$ & 0.007 & $13.02(11)$ & 0.29 & $30.23(13)$ & 0.004 \\
\hline
\end{tabular}


Appendix Table 3. Results of tests of goodness of fit to the Single Release Model for release groups of juvenile steelhead (hatchery and wild) from Lower Granite to McNary Dam in 2003.

\begin{tabular}{lcccccccc}
\hline & \multicolumn{2}{c}{ Overall } & \multicolumn{2}{c}{$\underline{\text { Test 2 }}$} & \multicolumn{2}{c}{ Test 2.C2 } & \multicolumn{2}{c}{ Test 2.C3 } \\
Release & $\chi^{2}$ & P value & $\chi^{2}$ & P value & $\chi^{2}$ & P value & $\chi^{2}$ & P value \\
\hline 30 Mar-05 Apr & 7.43 & 0.12 & 5.13 & 0.08 & 5.13 & 0.08 & NA & NA \\
06 Apr-12 Apr & 5.10 & 0.53 & 2.34 & 0.51 & 0.39 & 0.82 & 1.94 & 0.16 \\
13 Apr-19 Apr & 11.38 & 0.08 & 3.30 & 0.35 & 3.09 & 0.21 & 0.21 & 0.64 \\
20 Apr-26 Apr & 4.67 & 0.59 & 1.26 & 0.74 & 0.84 & 0.66 & 0.42 & 0.52 \\
27 Apr-03 May & 7.66 & 0.26 & 3.16 & 0.37 & 2.23 & 0.33 & 0.93 & 0.33 \\
04 May-10 May & 10.33 & 0.11 & 6.31 & 0.10 & 5.25 & 0.07 & 1.06 & 0.30 \\
11 May-17 May & 10.46 & 0.11 & 9.48 & 0.02 & 3.21 & 0.20 & 6.27 & 0.01 \\
18 May-24 May & 15.60 & 0.02 & 10.34 & 0.02 & 5.22 & 0.07 & 5.13 & 0.02 \\
25 May-31 May & 45.53 & 0.00 & 42.59 & 0.00 & 1.14 & 0.57 & 41.45 & 0.00 \\
01 Jun-07 Jun & 6.30 & 0.39 & 2.00 & 0.57 & 0.54 & 0.76 & 1.46 & 0.23 \\
\hline Total (d.f.) & $117.0(54)$ & $<0.001$ & $80.77(27)$ & $<0.001$ & $21.91(18)$ & 0.24 & $58.87(9)$ & $<0.001$ \\
\hline
\end{tabular}


Appendix Table 3. Continued.

\begin{tabular}{lccccccccc}
\hline & \multicolumn{2}{c}{ Test 3 } & \multicolumn{2}{c}{ Test 3.SR3 } & \multicolumn{2}{c}{ Test 3.Sm3 } & \multicolumn{2}{c}{ Test 3.SR4 } \\
Release & $\chi^{2}$ & P value & $\chi^{2}$ & P value & $\chi^{2}$ & P value & $\chi^{2}$ & P value \\
\hline 30 Mar-05 Apr & 2.29 & 0.32 & 2.25 & 0.13 & NA & NA & 0.04 & 0.84 \\
06 Apr-12 Apr & 2.76 & 0.43 & 1.05 & 0.31 & 1.27 & 0.26 & 0.44 & 0.51 \\
13 Apr-19 Apr & 8.08 & 0.04 & 3.33 & 0.07 & 1.03 & 0.31 & 3.72 & 0.054 \\
20 Apr-26 Apr & 3.42 & 0.33 & 0.01 & 0.94 & 3.33 & 0.07 & 0.08 & 0.77 \\
27 Apr-03 May & 4.49 & 0.21 & 0.81 & 0.37 & 2.81 & 0.09 & 0.88 & 0.35 \\
04 May-10 May & 4.02 & 0.26 & 0.04 & 0.84 & 0.07 & 0.80 & 3.92 & 0.048 \\
11 May-17 May & 0.98 & 0.81 & 0.78 & 0.38 & 0.19 & 0.66 & 0.01 & 0.92 \\
18 May-24 May & 5.26 & 0.15 & 0.60 & 0.44 & 2.14 & 0.14 & 2.52 & 0.11 \\
25 May-31 May & 2.95 & 0.40 & 0.11 & 0.74 & 1.19 & 0.28 & 1.65 & 0.20 \\
01 Jun-07 Jun & 4.30 & 0.23 & 3.12 & 0.08 & 1.17 & 0.28 & 0.01 & 0.92 \\
\hline Total (d.f.) & $36.26(27)$ & 0.11 & $9.86(9)$ & 0.36 & $13.18(9)$ & 0.15 & $13.23(9)$ & 0.15 \\
\hline
\end{tabular}


Appendix Table 4. Number of tests of goodness of fit to the Single Release Model conducted for weekly release groups of yearling chinook salmon and steelhead (hatchery and wild combined) from McNary Dam, and number of significant $(\alpha=0.05)$ test results, 2003.

\begin{tabular}{lccccccc}
\hline & \multicolumn{2}{c}{ Test 2.C3 } & & \multicolumn{2}{c}{ Test 3.SR4 } & \multicolumn{2}{c}{ Test 2+3 } \\
Spp. & sig. & & $\#$ & sig. & & sig. \\
\hline Chinook & 7 & 0 & 7 & 0 & 7 & 0 \\
Steelhead & 3 & 1 & 2 & 0 & 3 & 1 \\
\cline { 2 - 7 } Total & 10 & 1 & 9 & 0 & 10 & 1 \\
\hline
\end{tabular}


Appendix Table 5. Results of tests of goodness of fit to the Single Release Model for release groups of yearling chinook salmon (hatchery and wild) from McNary to Bonneville Dam in 2003.

\begin{tabular}{lllllll}
\hline & \multicolumn{2}{c}{ Overall } & \multicolumn{2}{c}{ Test 2.C2 } & \multicolumn{2}{c}{ Test 3.SR3 } \\
Release & $\mathrm{c}^{2}$ & P value & $\mathrm{c}^{2}$ & P value & $\mathrm{c}^{2}$ & P value \\
\hline 20 Apr-26 Apr & 0.16 & 0.92 & 0.00 & 0.96 & 0.16 & 0.69 \\
27 Apr-03 May & 0.24 & 0.89 & 0.14 & 0.71 & 0.10 & 0.75 \\
04 May-10 May & 0.05 & 0.98 & 0.04 & 0.84 & 0.01 & 0.92 \\
11 May-17 May & 2.06 & 0.36 & 0.11 & 0.74 & 1.95 & 0.16 \\
18 May-24 May & 0.09 & 0.96 & 0.02 & 0.90 & 0.07 & 0.79 \\
25 May-31 May & 0.51 & 0.78 & 0.22 & 0.64 & 0.29 & 0.59 \\
01 Jun-07 Jun & 1.14 & 0.57 & 0.44 & 0.51 & 0.70 & 0.40 \\
\hline Total (d.f.) & $4.24(14)$ & 0.99 & $0.96(7)$ & 0.99 & $3.29(7)$ & 0.86 \\
\hline
\end{tabular}


Appendix Table 6. Results of tests of goodness of fit to the Single Release Model for release groups of steelhead (hatchery and wild) from McNary to Bonneville Dam in 2003.

\begin{tabular}{lcccccc}
\hline & \multicolumn{2}{c}{ Overall } & \multicolumn{2}{c}{$\frac{\text { Test 2.C2 }}{2}$} & \multicolumn{2}{c}{ Test 3.SR3 } \\
Release & $\mathrm{c}^{2}$ & P value & $\mathrm{c}^{2}$ & P value & $\mathrm{c}^{2}$ & P value \\
\hline 27 Apr-03 May & NA & NA & NA & NA & NA & NA \\
04 May-10 May & NA & NA & NA & NA & NA & NA \\
11 May-17 May & NA & NA & NA & NA & NA & NA \\
18 May-24 May & 1.66 & 0.44 & 0.74 & 0.39 & 0.92 & 0.34 \\
25 May-31 May & 0.77 & 0.68 & 0.76 & 0.38 & 0.00 & 0.97 \\
01 Jun-07 Jun & 4.25 & 0.04 & 4.25 & 0.04 & 0.00 & 0.00 \\
\hline Total (d.f.) & $6.68(5)$ & 0.25 & $5.76(3)$ & 0.12 & $0.93(2)$ & 0.63 \\
\hline
\end{tabular}

